\author{
UNIVERSIDADE DE SÃO PAULO \\ INSTITUTO DE ENERGIA E AMBIENTE \\ PROGRAMA DE PÓS-GRADUAÇÃO EM ENERGIA
}

MARIO HENRIQUE CHAVES

UNIDADE DE CONTROLE DE MOTORES DE COMBUSTÃO INTERNA

BASEADA EM MICROCONTROLADOR E FPGA 
MARIO HENRIQUE CHAVES

\section{UNIDADE DE CONTROLE DE MOTORES DE COMBUSTÃO INTERNA BASEADA EM MICROCONTROLADOR E FPGA}

Dissertação apresentada ao Programa de PósGraduação em Energia do Instituto de Energia e Ambiente da Universidade de São Paulo para a obtenção do título de Mestre em Ciências.

Orientador: Prof $^{\circ}$. Dr$^{\circ}$ Hédio Tatizawa.

\section{SÃO PAULO \\ 2016}


AUTORIZO A REPRODUÇÃO E DIVULGAÇÃO TOTAL OU PARCIAL DESTE TRABALHO, POR QUALQUER MEIO CONVENCIONAL OU ELETRÔNICO, PARA FINS DE ESTUDO E PESQUISA, DESDE QUE CITADA A FONTE.

FICHA CATALOGRÁFICA

Chaves, Mario Henrique.

Unidade de controle de motores de combustão interna baseada em microcontrolador e FPGA. / Mario Henrique Chaves; orientador : Hédio Tatizawa-São Paulo, 2016.

121f.: il.; $30 \mathrm{~cm}$.

Dissertação (Mestrado em Ciências) - Programa de Pós-Graduação em Energia - Instituto de Energia e Ambiente da Universidade de São Paulo

1. Motores de combustão interna. 2. Circuitos FPGA . 3. Combustíveis - controle . I. Título. 
Nome: Chaves, Mario Henrique.

Título: Unidade de controle de motores de combustão interna baseada em microcontrolador e FPGA

Dissertação apresentada ao Programa de Pós-

Graduação em Energia do Instituto de Energia e Ambiente da Universidade de São Paulo para obtenção do título de Mestre em Ciências.

Aprovado em:

Banca Examinadora

Prof. Dr. Instituição:

Julgamento: Assinatura:

Prof. Dr. Instituição:

Julgamento: Assinatura:

Prof. Dr. Instituição:

Julgamento: Assinatura:

Prof. Dr. Instituição:

Julgamento: Assinatura: 


\section{AGRADECIMENTOS}

Inicialmente gostaria de agradecer a Deus por tudo que me foi permitido e por ter ao meu redor meus familiares, amigos e demais pessoas que fazem parte do meu caminho e me permitem aprender cada vez mais.

A meus pais Mario Lucio Chaves e Luzia Rodrigues de Oliveira que sempre se sacrificaram e trabalharam muito para que eu pudesse seguir meu caminho e atingir meus objetivos. Todo o amor e carinho destinados a mim são as coisas mais importantes e valiosas que já recebi de alguém em minha vida e fizeram de mim quem sou hoje.

Agradeço a minha irmã Diana de Oliveira Chaves que nunca me deixou quando precisei e sempre esteve disposta a me auxiliar quando podia. Aos meus avós Efigênia Profeta Chaves e Noé Gonçalves Chaves e a meus tios que, direta ou indiretamente, criaram uma base para mim e influenciaram muito nas minhas escolhas. Em especial agradeço a meu tio Erenildo Paulo Chaves que sempre me ajudou em meus projetos e sem seu auxilio não poderia ter chegado à fase final de ensaios desse trabalho.

Ao Professor Doutor Hédio Tatizawa por me orientar e estar sempre disposto e presente, dando oportunidades e me ajudando para que meu trabalho fosse conduzido da melhor maneira possível.

Aos professores Armando Antonio Maria Laganá, Alexandre Brincalepe Campo e Ricardo Pires, pela paciência e por estarem sempre prontos a me auxiliar e transmitir seus conhecimentos.

A minha namorada Marina Bueno que durante todo esse trabalho foi muito compreensiva.

Aos meus amigos Jefferson Pereira, Gabriel Lodos e Danilo Takaki que, durante nossa graduação, fizeram parte da primeira fase desse trabalho. Aos meus amigos Danilo Linhares e Rodrigo Teixeira que estiveram presentes durante o trabalho me ajudando com ideias, revisões e apoio em geral.

Por fim agradeço ao Instituto de Energia da USP pela estrutura disponibilizada e pelo acesso a materiais técnico e humano que foram fundamentais para o desenvolvimento desse trabalho. Também agradeço ao CNPQ pelo auxilio financeiro. 


\section{RESUMO}

CHAVES, Mario H. Unidade de Controle de Motores de Combustão Interna Baseada em Microcontrolador e FPGA. 2016. 120 f. Dissertação (Mestrado em Ciências) - Programa de Pós-Graduação em Energia da Universidade de São Paulo, São Paulo, 2016.

Neste trabalho são apresentados os resultados obtidos no desenvolvimento de uma unidade de controle para motores de combustão interna (UCM). A unidade foi desenvolvida com o intuito de facilitar os estudos de motores, por ser um sistema flexível e acessível. Para cálculos de rotinas de controle e acionamento de atuadores são utilizados, respectivamente, um microcontrolador e um FPGA, sendo que ambos são componentes de fácil obtenção e utilizados em placas de prototipagem encontradas no mercado (Arduino Due e Xula 2). O uso de um FPGA para executar o comando de atuadores se deve à alta velocidade de processamento, processamento paralelo e grande quantidade de portas digitais disponíveis, o que permite facilidade na expansão do sistema para comandos de múltiplos atuadores e o sincronismo desses com o sistema mecânico. O microcontrolador fica encarregado de executar as rotinas de cálculos que não exigem exato sincronismo, como rotinas de controle e comunicação com periféricos. A planta escolhida para ensaios da UCM é um motor ciclo Otto a álcool de 4 cilindros e 1.6 litros, com injeção multiponto. Ensaios foram realizados com o protótipo final e englobaram somente o controle do sistema de ignição do motor devido à facilidade de controle utilizando-se somente um parâmetro de entrada (velocidade) e devido ao controle de quantidade de combustível ser similar e utilizar as mesmas partes de código que o sistema de ignição.

Palavras-chave: UCM, ECU, controle de combustível, controle de ignição, FPGA, TPU, microcontrolador. 


\begin{abstract}
CHAVES, Mario H. Engine Control Unit based on Microcontroller and FPGA. 2016. 120

f. Master's Dissertation - Graduate Program on Energy, Universidade de São Paulo, São Paulo, 2016.

In this work is presented the development of a flexible and accessible engine control unit for research purposes. For the calculations of the control routines and to drive the actuators synchronously, are used respectively, a microcontroller and an FPGA. The integrated circuits selected are easily accessible and are used in common prototyping boards found on the market (Arduino Due and Xula 2). The use of an FPGA to control the activation of the actuators is due the high speed, parallel processing and the large number of IO's, which allows the easy expansion of the system to drive more actuators, synchronized or not, with the mechanical system. The microcontroller calculates the routines that don't need an exact synchronism of the electronic system with the mechanical system, like control routines and communication tasks. The selected mechanical system for tests is a 1.6 Liter Otto engine with multipoint fuel injection and is powered with ethanol. Tests were conducted using the final board prototype only for the ignition system, because of the easy of control using a few parameters, and because ignition FPGA's code is almost the same used to drive fuel injection actuators.
\end{abstract}

Keywords: electronic control unit, ECU, engine management, FPGA, TPU, microcontroller. 


\section{LISTA DE FIGURAS}

Figura 1 - Construção básica de um motor ciclo Otto ou diesel de um cilindro.

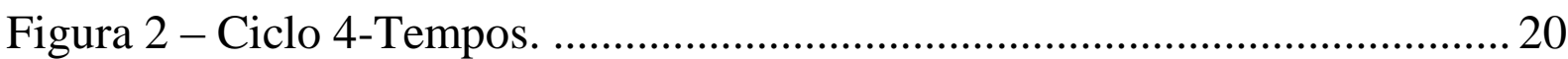

Figura 3 - Ciclo de quatro tempos ocorrendo em um motor ciclo Otto. ............ 21

Figura 4 - Sistemas de admissão e de escape. ............................................... 22

Figura 5 - Formação de poluentes. .................................................................... 24

Figura 6 - Sistema de injeção eletrônica de combustível. ................................... 26

Figura 7 - Sistema básico de ignição com duas bobinas e centelha perdida...... 28

Figura 8 - Sensor de relutância magnética. .......................................................... 30

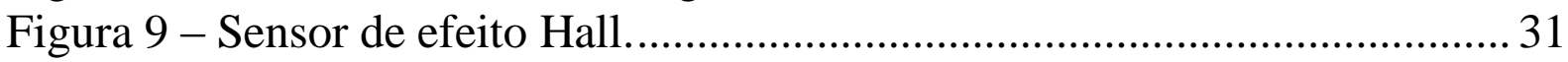

Figura 10 - Sensor de efeito Hall simplificado................................................... 32

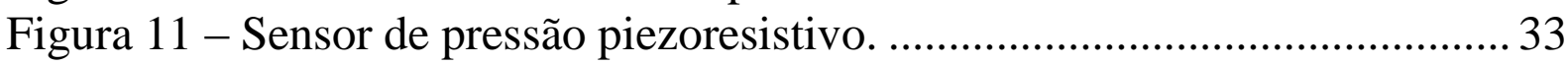

Figura 12 - Saída do sensor de oxigênio de banda estreita ................................ 34

Figura 13 - Saída do sensor de oxigênio de banda larga.................................... 34

Figura 14 - Sensor de temperatura do ar (IAT) ................................................. 35

Figura 15 - Sensor de temperatura do liquido de arrefecimento (CLT) ............. 35

Figura 16 - Curva característica do sensor NTC. .............................................. 36

Figura 17 - Corpo de borboleta com sensor de posição da válvula..................... 37

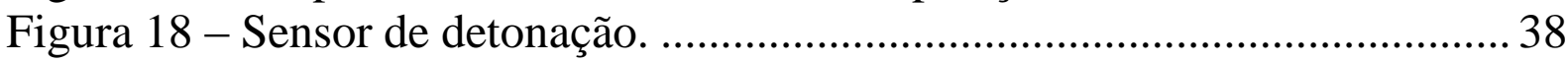

Figura 19 - Sensor de Fluxo de massa de $\operatorname{Ar}(\mathrm{MAF})$........................................... 39

Figura 20 - Bico injetor de combustível ............................................................. 40

Figura 21 - Bobina de ignição - Circuito........................................................ 41

Figura 22 - Atuador de marcha lenta.......................................................... 42

Figura 23 - Corpo de borboleta com servomecanismo (borboleta eletrônica)... 43

Figura 24 - Esquema de controle Feedforward de combustível. ........................ 46

Figura 25 - Esquema de controle feedback de razão Ar-Combustível............... 47

Figura 26 - Mapa de avanço do ponto de ignição. ............................................. 48

Figura 27 - Estratégia de controle de detonação baseada no ponto de ignição.. 49

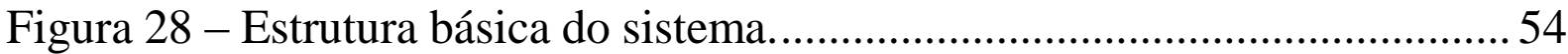

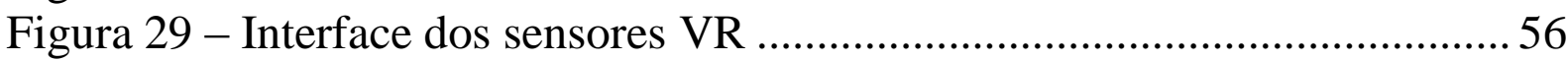

Figura 30 - Limiar Adaptativo........................................................................... 56

Figura 31 - Circuito de potência para comando de bicos injetores .................... 57

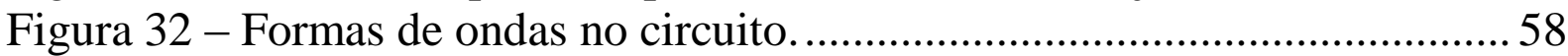

Figura 33 - Saída de potência para comando de bobinas de ignição .................59

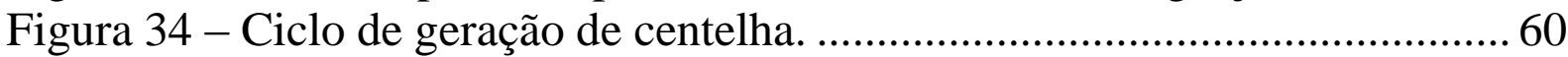

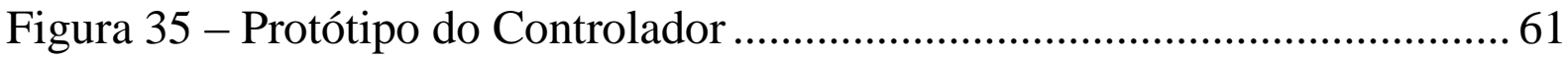

Figura 36 - Encapsulamentos TQFP144 (a) e FT256 (b) ...................................63

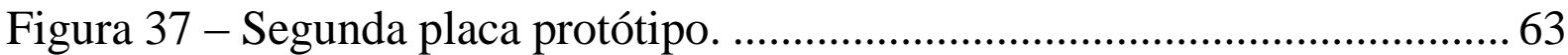

Figura 38 - Circuito de configuração e comunicação SPI do FPGA. .................. 64

Figura 39 - Rotina de configuração do FPGA.................................................... 65 
Figura 40 - Interface para gravação do arquivo de configuração do FPGA. ..... 66

Figura 41 - Abertura e configuração da porta serial.......................................... 67

Figura 42 - Código para abrir arquivo de configuração..................................... 68

Figura 43 - Identificação da quantidade de páginas e de partes do arquivo. .... 68

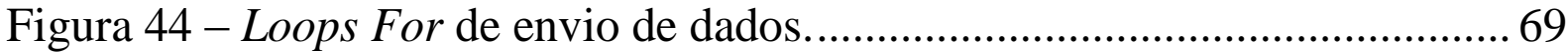

Figura 45 - Entradas analógicas para sensores resistivos................................ 70

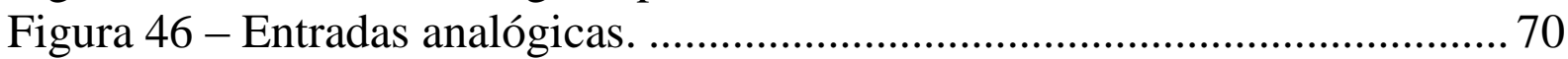

Figura 47 - Ligação entre Microcontrolador e FPGA. ..................................... 71

Figura 48 - TPU completa com periféricos.................................................... 72

Figura 49 - Rotinas executadas pelo microcontrolador...................................... 73

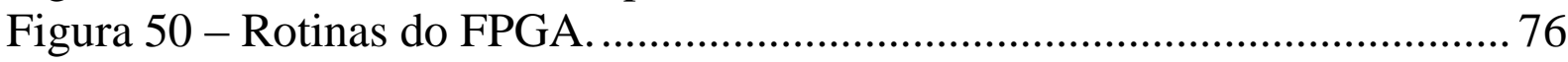

Figura 51 - Núcleo de estimação da posição do eixo ............................................ 77

Figura 52 - Validação de leituras e detecção de falha.........................................78

Figura 53 - Sinal de posição do eixo, defeituoso e normal. ................................ 79

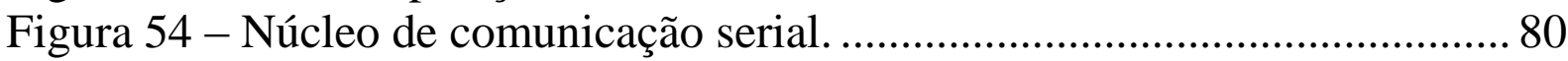

Figura 55 - Recebimento de dados via serial. ................................................... 81

Figura 56 - Disponibilização de dados lidos. ………….................................... 81

Figura 57 - Envio de dados via serial (Slave para Mestre). .............................. 82

Figura 58 - Núcleo de separação de dados e buffer. ......................................... 83

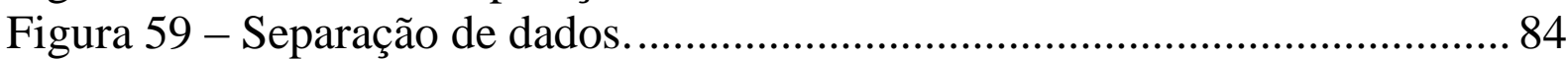

Figura 60 - Indicação de atuador completamente atualizado............................. 84

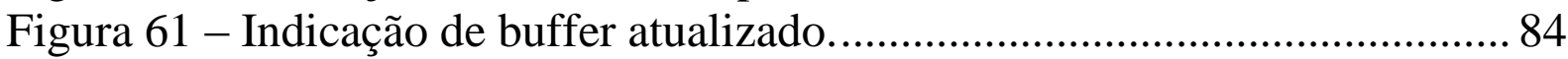

Figura 62 - Núcleo de cálculos de posição de acionamento de atuadores. ........ 86

Figura 63 - Exemplo de comando de bobina de ignição ...................................... 86

Figura 64 - Cálculo de posição ideal para inicio de energização da bobina. .....87 87

Figura 65 - Núcleo de comando de atuadores................................................. 88

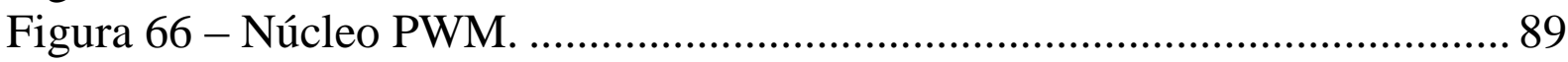

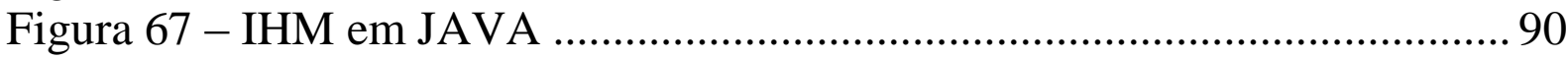

Figura 68 - Tabela de avanço de ponto de ignição............................................ 91

Figura 69 - Tabelas de configuração dos eixos das tabelas de avanço de ignição

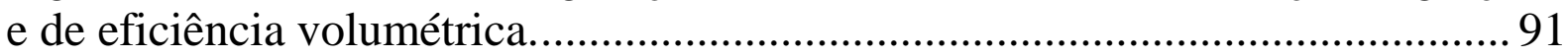

Figura 70 - Entrada de sinal acima do nível de saturação................................93

Figura 71 - Sinal de entrada no limite de saturação ............................................ 94

Figura 72 - Diagrama de bode do ganho do circuito de entrada em função da

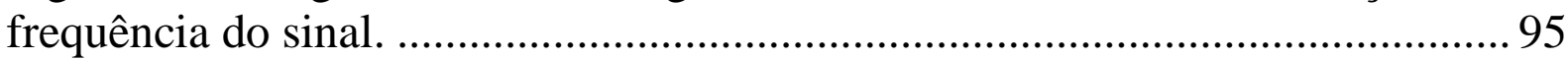

Figura 73 - Atenuação dos sinais de entrada................................................. 96

Figura 74 - Circuito programado para gerar um eco na linha de comunicação

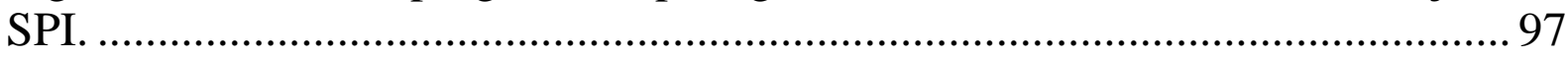

Figura 75 - Sinais da roda dentada do virabrequim e do sensor de fase............ 98

Figura 76 - Ensaio de código do sensor de posição do eixo do motor............... 98

Figura 77 - Verificação da detecção dos dentes da roda fônica simulada. ........ 99

Figura 78 - Verificação da detecção da falha da roda dentada.......................... 100

Figura 79 - Vetor com ângulos de comando. ................................................... 100 
Figura 80 - Sinal de ensaio de estimação da posição do eixo (Detalhe).......... 101

Figura 81 - Sinal de ensaio de estimação da posição do eixo (Estendido). ..... 101 Figura 82 - Ensaios de acionamento com a roda dentada simulada a 850 RPM.

Figura 83 - Conjunto de encoder e motor

Figura 84 - Detalhes da marcação no disco do encoder e da falha de janelas. 104 Figura 85 - Ensaios de ângulos de comando. ................................................... 105

Figura 86 - Marca na polia do comando de válvulas. ...................................... 106

Figura 87 - Indicação do ponto onde ocorrem os pulsos de ignição do primeiro

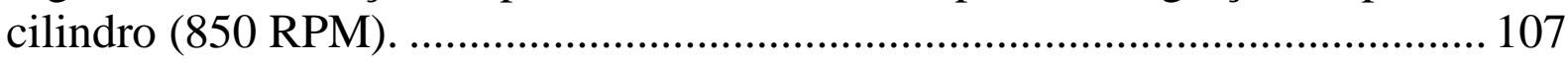

Figura 88 - Tabela de avanço de ponto de ignição e campo de compensação. 107

Figura 89 - Posição de acionamento sem o ajuste........................................... 108

Figura 90 - Sistema de ignição experimental. ............................................... 108

Figura 91 - Verificação da detecção e da validação dos períodos dos dentes.. 109

Figura 92 - Verificação da deteç̧ão da falha de dente...................................... 109

Figura 93 - Planta utilizada nos ensaios. .......................................................... 111 


\section{LISTA DE TABELAS}

Tabela 1 - Características principais do FPGA (XC6SLX25)...........................55

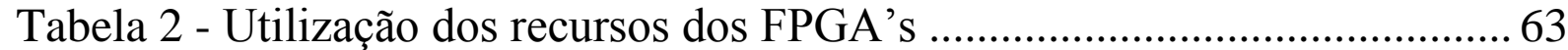

Tabela 3 - Ganhos do filtro de primeira ordem em função da frequência.......... 94

Tabela 4 - Características da planta utilizada...................................................... 110 


\section{LISTA DE ABREVIATURAS E SIGLAS}

A

$\mathrm{A} / \mathrm{D}$

AFR

$\mathrm{cc} / \mathrm{min}$

C.I.

CLT

CMOS

$\mathrm{CO}$

$\mathrm{CO}_{2}$

CPU

EEPROM

EGR

$\mathrm{HC}$

$\mathrm{Hz}$

I2C

IAT

IDE

$\mathrm{kPa}$

LED

MAF

MAP

MAT

MOSFET

NOx

PC

PID

PMI

PMS

ppm

PPP

PWM ampère

analógico para digital

Air fuel Ratio

centímetros cúbicos por minuto

Circuito Integrado

Coolant Liquid Temperature

Complementary Metal Oxide Semiconductor

molécula de monóxido de carbono

molécula de dióxido de carbono

Central Processing Unit

Electrically-Erasable Programmable Read-Only Memory

Exhaust Gas Recirculation

hidrocarbonetos

unidade de medida de frequência

barramento serial de comunicação Inter-Integrated Circuit

Intake Air Temperature

Integrated Development Environment

unidade de medida de pressão em quilo Pascal

light-emitting diode

Manifold Air Flow

Manifold Absolute Pressure

Manifold Air Temperature

Metal Oxide Semiconductor Field Effect Transistor

moléculas de óxidos de nitrogênio

Personal Computer

Proporcional-Integral-Derivativo

Ponto Morto Inferior

Ponto Morto Superior

partes por milhão

Peak Pressure Position

Pulse Width Modulation 


$\begin{array}{ll}\text { RPM } & \text { Rotações por minuto } \\ \text { RTOS } & \text { Real Time Operating System } \\ \text { TPS } & \text { Throttle Position Sensor } \\ \text { TPU } & \text { Time Processing Unit } \\ \text { TWC } & \text { Three-Way Catalytic Converter } \\ \text { UCM } & \text { Unidade de Controle do Motor } \\ \text { USB } & \text { Universal Serial Bus } \\ \text { V } & \text { volts } \\ \text { VHDL } & \text { VHSIC Hardware Description Language } \\ \text { VR } & \text { Variable Reluctance } \\ \text { VVT } & \text { Variable Valve Timing }\end{array}$




\section{LISTA DE SÍMBOLOS.}

$\eta \quad$ eficiência volumétrica do motor

$\lambda$ razão entre relações de ar-combustível real e ideal

$\rho \quad$ densidade dos gases $\left(\mathrm{kg} / \mathrm{m}^{3}\right)$

$\omega \quad$ velocidade angular

$\Omega \quad$ símbolo da unidade de medida de resistência elétrica $\mathrm{Ohm}$

$\theta \quad$ ângulo em graus 


\section{SUMÁRIO}

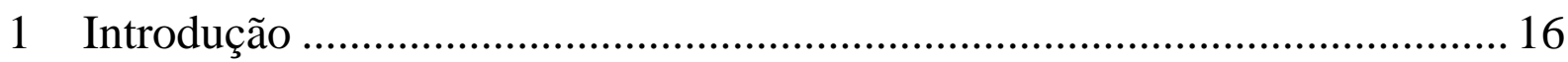

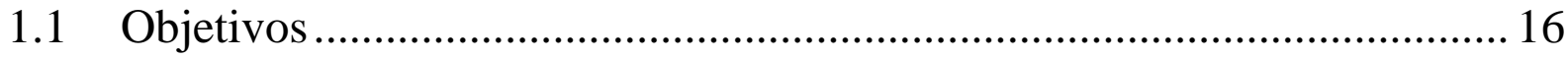

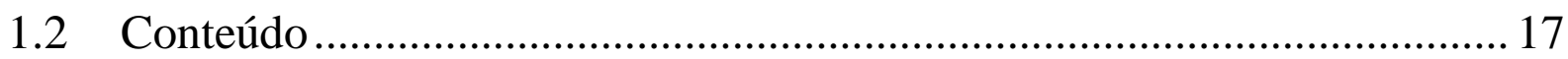

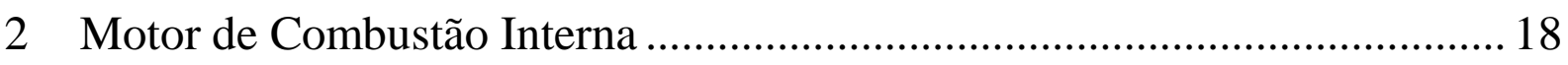

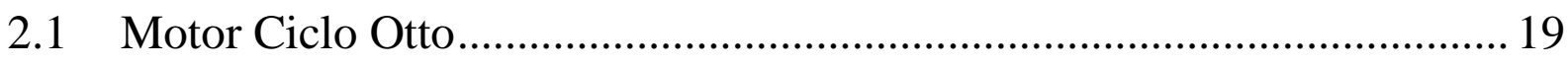

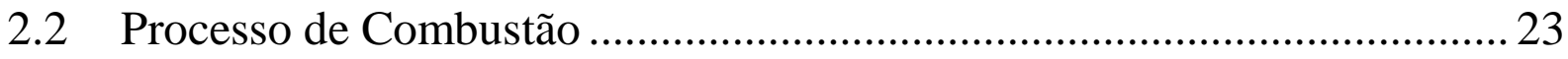

2.3 Sistemas Eletrônicos de Ignição e Injeção de Combustível ....................... 25

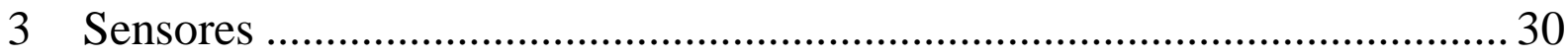

3.1 Posição angular do eixo do motor (Relutância variável e Hall) ................. 30

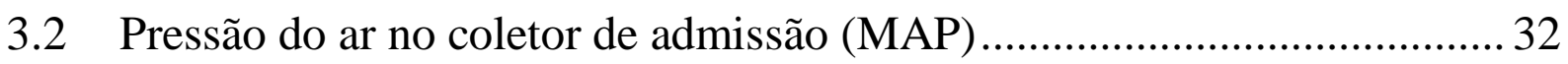

3.3 Sensor de oxigênio (Sonda Lambda) ........................................................ 33

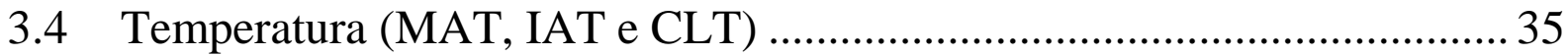

3.5 Posição da válvula borboleta (TPS)......................................................... 36

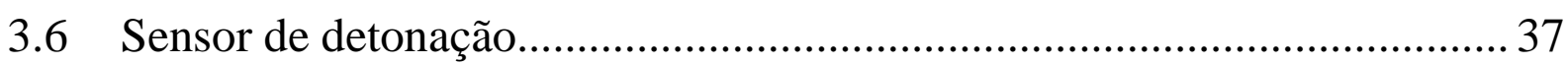

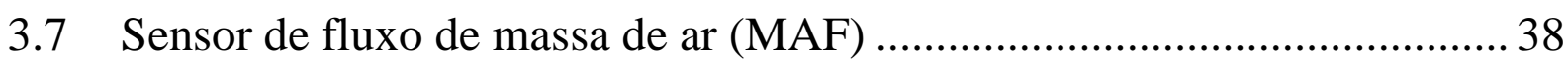

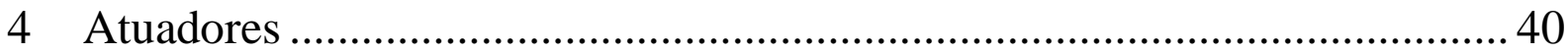

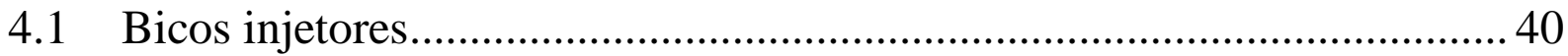

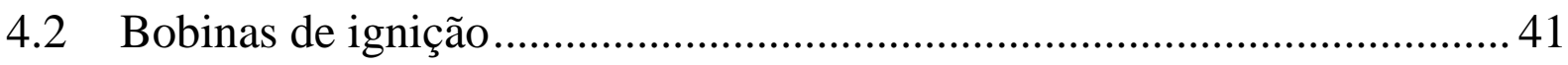

4.3 Borboleta Eletrônica e Atuador de Marcha lenta ....................................... 42

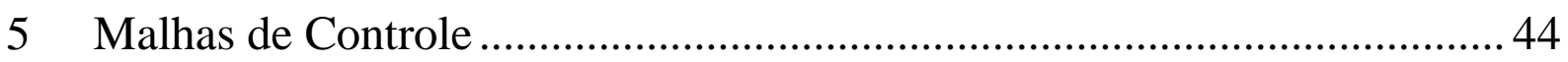

5.1 Malha Feedforward de injeção de combustível ........................................ 44

5.2 Malha Feedback de razão Ar-Combustível .............................................. 46

5.3 Malha Feedforward de avanço de ignição ................................................ 47

5.4 Malha de Controle de Detonação …………………................................... 48

6 Protótipo da Unidade de Controle ………….............................................. 51

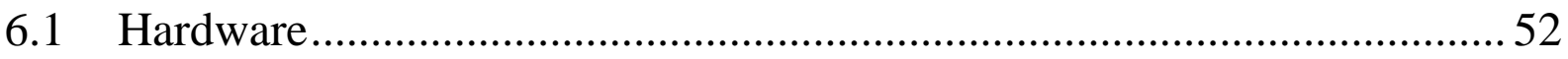

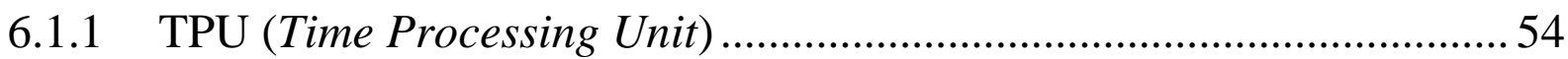

6.1.2 Tratamento do Sinal do Sensor de Relutância Variável......................... 56

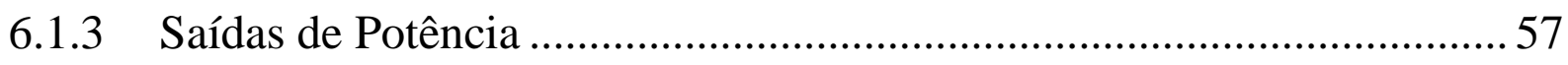

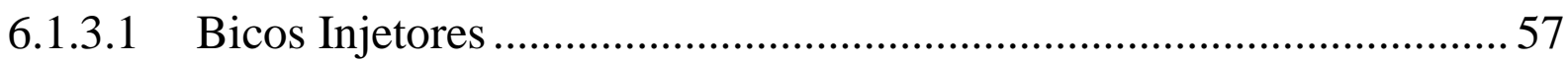


6.1.3.2 Bobina de ignição ............................................................................. 59

6.1.4 Primeira placa protótipo desenvolvida ..................................................... 61

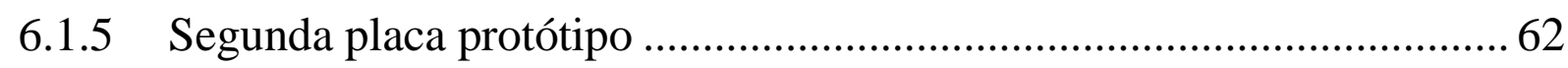

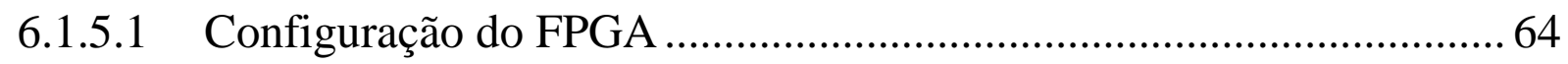

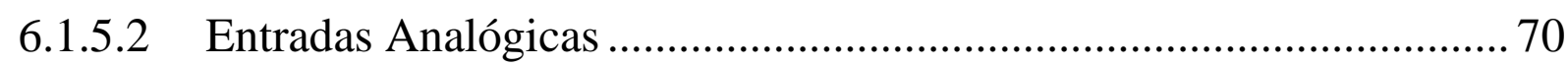

6.2 Códigos da TPU e do Microcontrolador................................................... 71

6.2.1 Rotinas de código do microcontrolador ................................................ 72

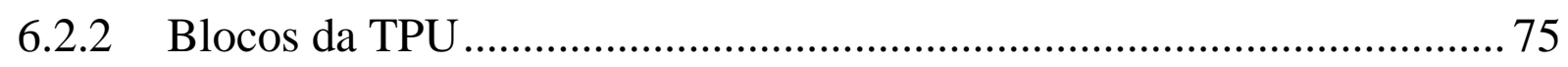

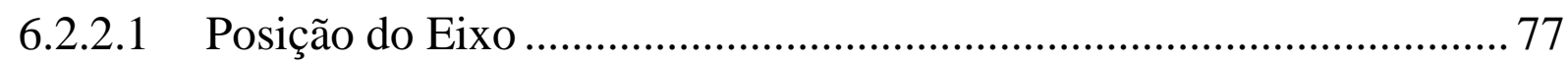

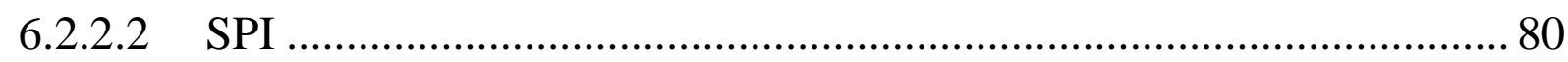

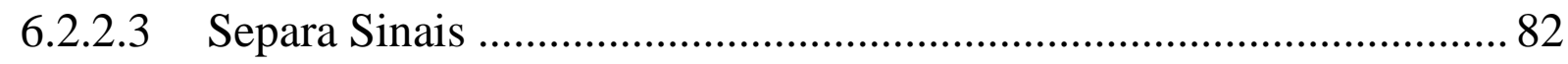

6.2.2.4 Cálculos para acionamento dos atuadores......................................... 85

6.2.2.5 Comando das Bobinas e Bicos Injetores ............................................ 88

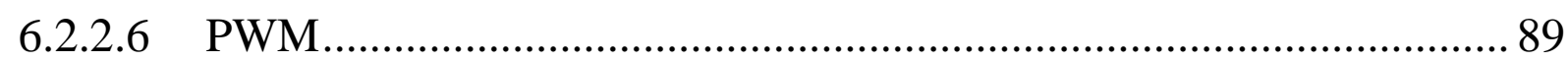

6.3 Interface Homem Máquina ............................................................... 90

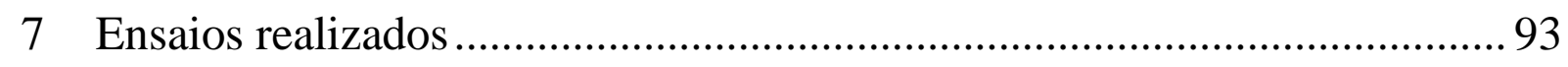

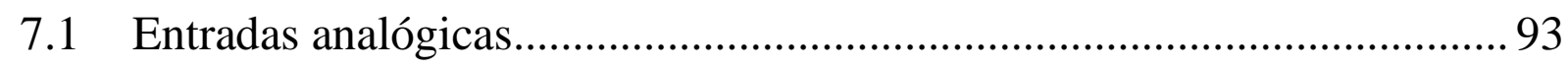

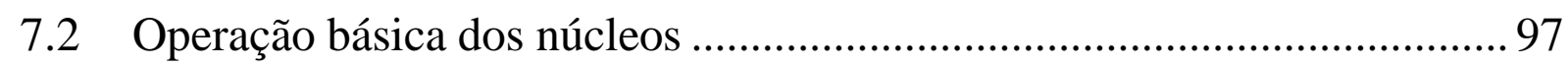

7.3 Verificação em bancada........................................................................... 103

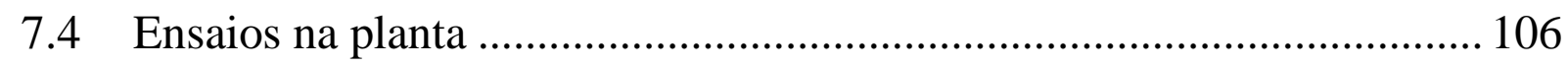

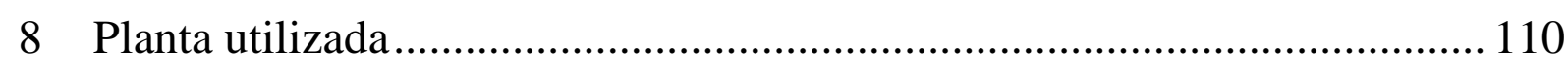

9 Conclusões e Sugestões para trabalhos futuros ........................................... 112

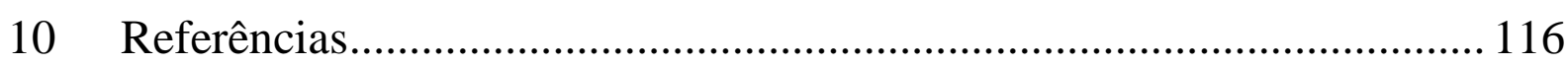




\section{Introdução}

Os motores de combustão interna são a forma de propulsão mais frequentemente utilizada em veículos de passeio. Com o aumento das restrições impostas por governos sobre as emissões de gases, os fabricantes se veem obrigados a investir no desenvolvimento de tecnologias que possibilitem cumprir os limites estabelecidos (Guzzella e Onder, 2010). São diversas as técnicas utilizadas para a redução de emissões, entre elas estão: o aprimoramento dos sistemas mecânicos, o desenvolvimento de melhores componentes e a aplicação de sistemas de controle eletrônicos com o intuito de manter o sistema trabalhando sempre no ponto ótimo designado pelo projetista, conciliando potência, eficiência e níveis de emissões dentro dos padrões.

Para o desenvolvimento e testes de controladores durante pesquisas, há a necessidade de um sistema flexível e com poder de processamento compatível com a proposta de controlador. No mercado, é possível encontrar alguns sistemas que suprem tais necessidades, no entanto, apresentam altos custos (Drivven e Bosch Motorsports) ou pouca liberdade de configuração e programação (Megasquirt ${ }^{\circledR}$ ). O desenvolvimento de tecnologia nacional em sistemas automotivos é muito interessante tanto para capacitação de profissionais na área quanto para a expansão da indústria nesse segmento. Com o aumento significativo de módulos eletrônicos embarcados nos veículos há grande importância de estudos nessa área.

\subsection{Objetivos}

O objetivo principal do trabalho é o desenvolvimento de uma unidade de controle para motores de combustão interna (UCM). O sistema deve apresentar, principalmente, as seguintes características:

- Capacidade para gerenciamento dos sistemas de ignição e injeção de combustível.

- Possibilidade de reconfiguração e inclusão de novos sensores e atuadores.

- Baixo custo de fabricação.

- Uso de softwares de código livre.

Os objetivos secundários são: 
- Desenvolver uma introdução básica sobre os sistemas existentes de gerenciamento de motores.

- Apresentação do processo de desenvolvimento da UCM.

- Levantamento de possíveis melhorias a serem realizadas em trabalhos futuros.

\subsection{Conteúdo}

No primeiro capítulo do trabalho é apresentada a introdução e os objetivos gerais e específicos. O segundo capítulo é utilizado para apresentar a revisão bibliográfica sobre os principais assuntos relacionados a motores de combustão interna e controle desses.

Inicialmente, há uma breve visão histórica dos motores de combustão interna, seguido pelo funcionamento de motores de quatro tempos e sistemas geralmente utilizados para ignição e alimentação de combustível.

No terceiro capítulo, são apresentados os principais sensores utilizados em sistemas de gerenciamento de motores. Da mesma maneira, o quarto capítulo faz uma breve apresentação dos atuadores comuns, explicando o funcionamento básico desses componentes.

No quinto capítulo, é feita uma discussão acerca das principais malhas de controle de um motor de combustão interna, foram levadas em consideração as malhas feedforward e feedback de ignição e injeção de combustível.

No sexto capítulo, é apresentado o protótipo do controlador desenvolvido, mostrando os motivos para escolha dos componentes de hardware e software. Os fluxos de trabalho dos códigos do sistema são explicados.

O sétimo capítulo apresenta todos os ensaios realizados no sistema desenvolvido. Inicialmente, são descritos os ensaios realizados com sensores simulados pelo FPGA, em seguida, os ensaios realizados com um simulador físico em bancada e por último em um motor de um veículo de passeio. No oitavo capítulo, este motor utilizado para ensaios é apresentado. 


\section{Motor de Combustão Interna}

A função de motores de combustão é converter a energia química de um combustível em energia mecânica. Para motores de combustão interna, essa conversão é realizada com a transferência da energia liberada pela queima de um combustível, dentro do motor, para o fluido de trabalho (HEYWOOD, 1988). O fluido de trabalho, inicialmente, é a mistura arcombustível, sendo convertido nos gases resultantes do processo de combustão (KLEIN; ERIKSSON, 2004).

Dentre os motores de combustão interna, encontram-se os motores alternativos, rotativos e de impulso. A maioria dos veículos automotores utiliza o sistema alternativo, que é caracterizado pelo movimento de vaivém do conjunto de biela e pistão (BRUNETTI, 2012), sendo que o tipo de motor de quatro tempos é o mais empregado.

Nicolaus Otto apresentou em 1876 seu protótipo de motor de quatro tempos que tinha peso e tamanho muito inferiores aos dos sistemas existentes, o que veio por iniciar a indústria do motor de combustão interna, no entanto, devido a uma patente de Alphonse Beau de Rochas encontrada em 1884 existem dúvidas sobre a validade da patente de Otto (HEYWOOD, 1988). Rochas teria concebido a teoria de motores com quatro tempos por volta de 1862, não tendo construído nenhum motor aplicando sua teoria (GUEDES, 2014).

Com a invenção de Otto houve um grande avanço na área e muitos outros sistemas vieram a ser desenvolvidos e comercializados, entre eles podem-se citar os motores de dois tempos, o ciclo Diesel e décadas depois, por volta de 1957, o motor rotativo (Wankel). Entre 1940 e 1952 o problema da poluição é discutido e demonstrado pelo professor A. J. HaagenSmit. No começo de 1960, devido a estes estudos, nos Estados Unidos da América foram aplicados padrões de emissões, obrigando a indústria a investir no desenvolvimento de sistemas mais eficientes e limpos.

Os sistemas de controle de alimentação de combustível e de ignição desenvolvidos nas últimas décadas em conjunto com o conversor catalítico são três dos principais contribuidores para o aumento de eficiência dos motores e redução das emissões de poluentes. Nas últimas décadas houve quase que total migração dos fabricantes que substituíram os sistemas puramente mecânicos (carburador e distribuidor) por sistemas controlados eletronicamente, restando o uso de carburadores e distribuidores somente para motores de máquinas pequenas (MOHSIN et al., 2014; BRUNETTI, 2012). 


\subsection{Motor Ciclo Otto}

A estrutura construtiva dos motores ciclo Otto e Diesel é basicamente a mesma (figura 1), são motores alternativos que utilizam êmbolos (pistões) realizando um movimento de vaivém de acordo com os tempos do ciclo, subindo até o ponto onde a câmara de combustão apresenta menor volume (Ponto Morto Superior) e descendo até o ponto onde a câmara apresenta maior volume (Ponto Morto Inferior) (HEYWOOD, 1988).

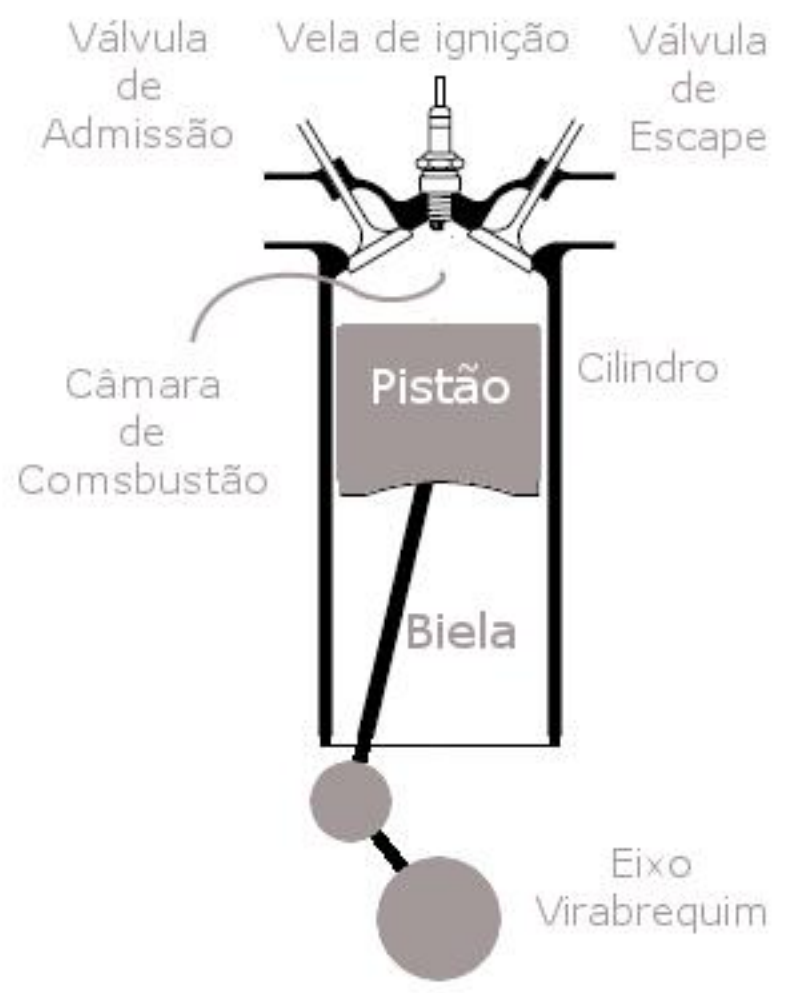

Figura 1 - Construção básica de um motor ciclo Otto ou diesel de um cilindro.

O que difere os dois tipos de motores é a forma como a mistura ar-combustível é formada e qual o tipo de ignição dessa mistura. Nos motores ciclo Otto, a mistura pode ser formada tanto antes da válvula de admissão (port injection) quanto diretamente dentro do cilindro (injeção direta). No caso dos motores a diesel, a injeção sempre é feita dentro do cilindro e no momento da queima. Nesses motores, a queima do combustível é iniciada devido à alta taxa de compressão, o que é realizado utilizando-se uma centelha no caso dos motores ciclo Otto. Os dois tipos de motores são caracterizados por realizar o ciclo 
denominado de 4-Tempos, que é composto por quatro processos sofridos pelo fluido de trabalho para a produção de trabalho (BRUNETTI, 2012).

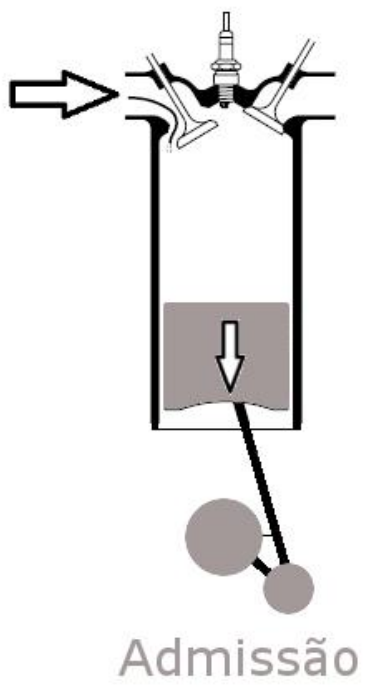

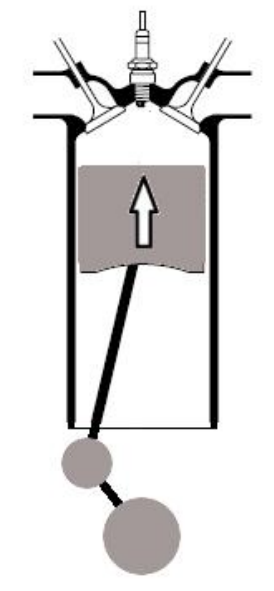

Compressão

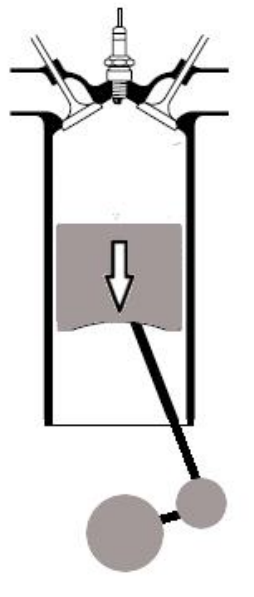

Expansão

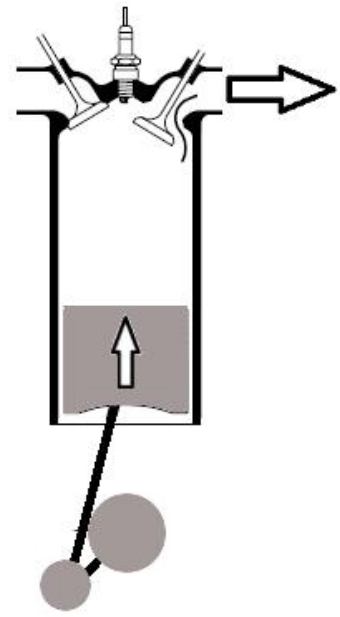

Escape

Figura 2 - Ciclo 4-Tempos.

Os quatro tempos do ciclo são descritos a seguir (figura 2):

- Tempo de Admissão: Com a válvula de admissão aberta o pistão realiza o deslocamento do PMS (Ponto Morto Superior) ao PMI (Ponto Morto Inferior). Durante o movimento, o pistão provoca a indução da mistura de ar-combustível, ou somente de ar (motores com injeção direta).

- Tempo de Compressão: A válvula de admissão é fechada e os gases admitidos são comprimidos quando o pistão é movido do PMI ao PMS. Próximo ao PMS, uma centelha é gerada na vela de ignição e a mistura entra em combustão.

- Tempo de Expansão: A energia liberada durante o processo de combustão provoca o aquecimento dos gases comprimidos e o consequente aumento de pressão. A pressão exercida sobre a superfície do pistão gera uma força resultante que é transmitida pela biela para o eixo virabrequim, provocando o movimento de descida para o PMI do pistão e o movimento de giro do eixo.

- Tempo de Escape: Ao final do tempo de expansão os gases aquecidos já geraram trabalho e precisam ser expelidos, para isso a válvula de admissão é mantida fechada e a de escape é aberta. Quando o pistão se move do PMI ao PMS os gases são bombeados para fora do motor. 
Ao final do tempo de escape, o motor volta ao ciclo de admissão e a sequência de tempos é repetida. A tarefa de abrir e fechar as válvulas de admissão e escape é realizada por um eixo chamado Eixo Comando de Válvulas. Este componente do motor é construído como uma barra de ferro com diversos ressaltos que empurram as válvulas para baixo e para cima conforme o eixo gira. O eixo comando de válvulas é comandado diretamente pelo eixo virabrequim através de correias, correntes ou engrenagens.

$\mathrm{Na}$ figura 3 é apresentada a sequência de tempos executada em um motor de quatro cilindros. Como observado, o ciclo inteiro ocorre durante as duas voltas do eixo $\left(720^{\circ}\right)$.

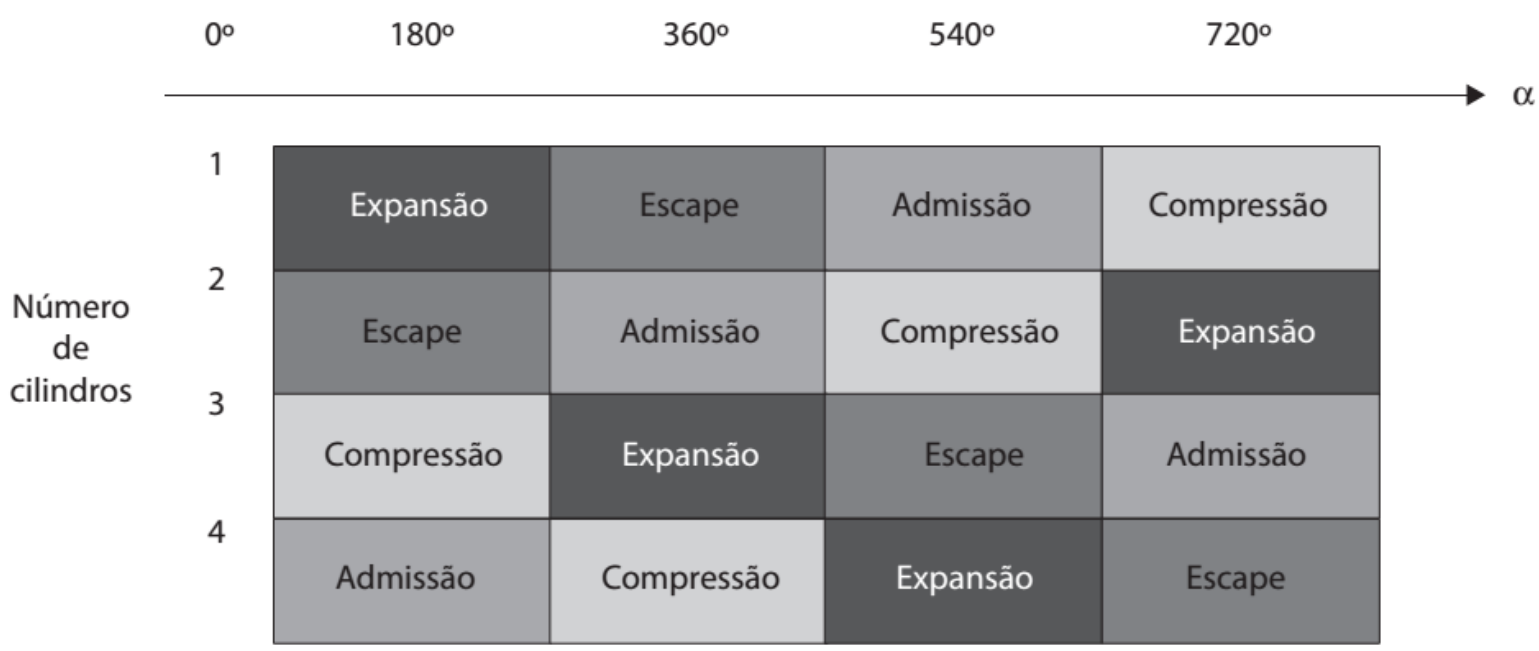

Ciclos do motor

Figura 3 - Ciclo de quatro tempos ocorrendo em um motor ciclo Otto. Fonte: (BRUNETTI, F., 2012)

Duas características importantes sobre os motores são relacionadas a seguir:

- Taxa de Compressão: A taxa de compressão é a razão entre os volumes internos do cilindro e câmara de combustão, com o pistão no PMI e no PMS (equação 1). A elevação da taxa de compressão permite o aumento de eficiência do ciclo, estando limitada por características de detonação do combustível (SOUZA DE ANDRADE, 2007).

$$
\text { Taxa }=\frac{\text { Volume Câmara }_{P M I}+\text { Volume Cilindro }_{P M I}}{\text { Volume Câmara }{ }_{P M S}+\text { Volume Cilindro }_{P M S}}
$$

- Eficiência Volumétrica: Indica a eficiência com que o motor admite a mistura de arcombustível ou só de ar. Considerando-se a frequência com que ocorrem os tempos de 
admissão e o volume do cilindro do motor, pode-se calcular o volume teórico de ar que o motor deveria admitir. A eficiência volumétrica é a razão entre o volume real sendo admitido pelo motor e o volume teórico.

Os valores de eficiência volumétrica do motor mudam de acordo com diversas variáveis. Para controle feedforward, é muito comum o uso de tabelas estáticas de eficiência volumétrica, que estão em função da velocidade angular do eixo do motor e da pressão dentro do coletor de admissão. Outros fatores como a quantidade de combustível injetada e a temperatura do motor também influenciam na eficiência volumétrica e são considerados pelas estratégias de controle (GUZELLA; ONDER, 2010).

O coletor de admissão é um componente do sistema de admissão de ar do motor e é responsável por conduzir os gases até as válvulas de admissão. Geralmente, no coletor de admissão, são posicionados os sensores de pressão do ar (MAP), de temperatura do ar (MAT) e os bicos injetores de combustível (motores sem injeção direta de combustível) (figura 4).

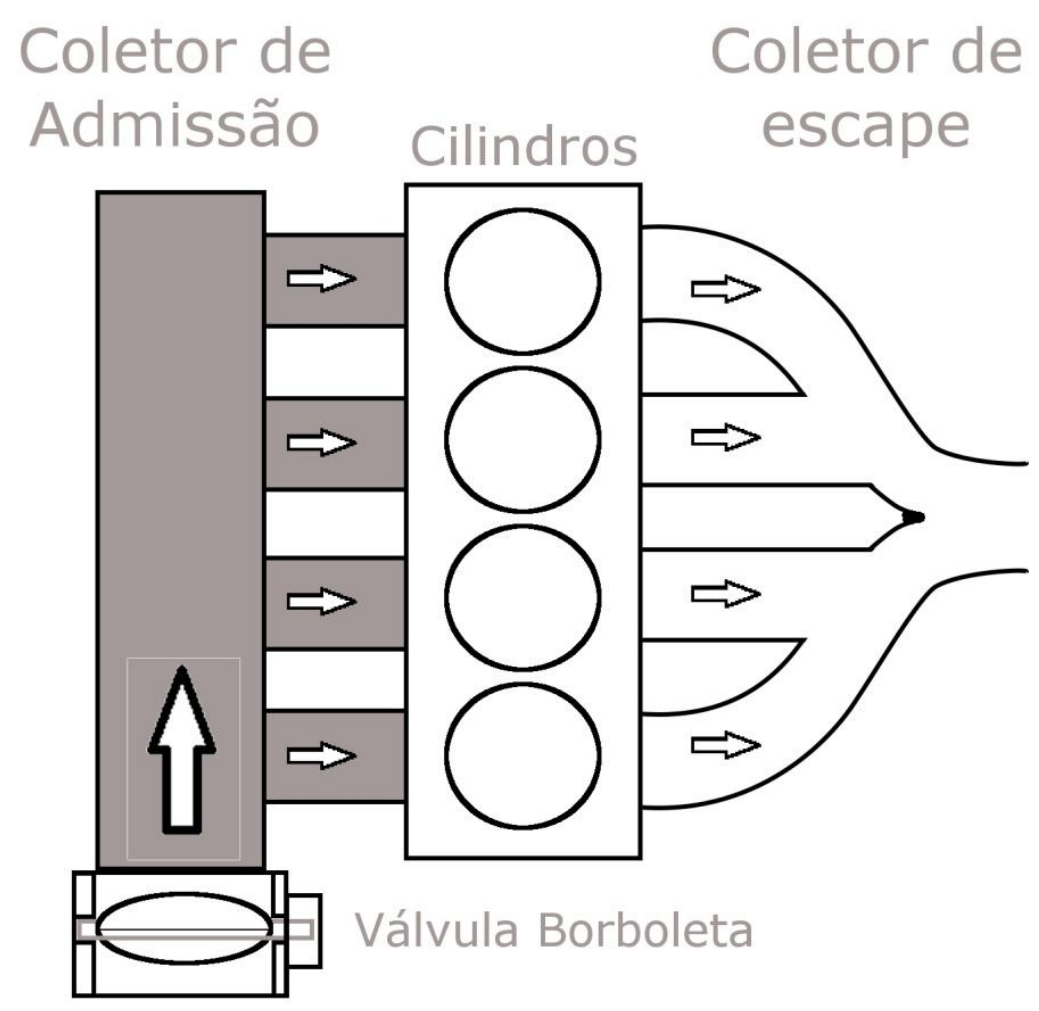

Figura 4 - Sistemas de admissão e de escape.

O fluxo de massa de ar é controlado por uma válvula posicionada na entrada do coletor de admissão. Nessa válvula é posicionado o sensor de posição da válvula borboleta (TPS). 
Para conduzir os gases queimados, é utilizado um componente chamado de coletor de escape, também composto por dutos como o coletor de admissão. O coletor de escape é conectado a outro duto, onde estão o conversor catalítico e outros componentes para redução de ruídos produzidos pelos gases de escape.

\subsection{Processo de Combustão}

A dinâmica da combustão dos gases dentro do cilindro do motor é dada por um processo químico dependente de diversas características do motor e do combustível. A combustão é iniciada com uma centelha produzida entre os eletrodos da vela de ignição, gerando o início da queima e uma frente de chama que se propaga para realizar a queima de todo o combustível. Após a geração da centelha, há um atraso para o início da queima devido às taxas de reações químicas na câmara, o que é influenciado diretamente pelas características físicas da mistura ar-combustível, como quantidade de combustível, temperatura e pressão (SOUZA DE ANDRADE, 2007).

A massa de combustível ideal para a formação da mistura ar-combustível permite gerar uma reação balanceada em que há como produtos da queima a formação de CO2 (dióxido de carbono), água e gases inertes presentes no ar atmosférico (PUJATTI, 2007). A equação química 2 representa uma reação balanceada entre álcool etílico e ar atmosférico (HEYWOOD, 1988).

$$
\mathrm{C}_{2} \mathrm{H}_{5} \mathrm{OH}+3\left(\mathrm{O}_{2}+3.773 \mathrm{~N}_{2}\right)=2 \mathrm{CO}_{2}+3 \mathrm{H}_{2} \mathrm{O}+11.32 \mathrm{~N}_{2}
$$

Para que haja uma queima completa no caso da reação da equação 2, a relação arcombustível (AFR - Air Fuel Ratio) deve ser de nove partes de massa de ar para cada uma parte de massa de combustível. Esse tipo de reação é chamada de combustão estequiométrica e idealmente gera como produtos, água, $\mathrm{CO}_{2}$ e gases que não participam da reação, como o nitrogênio. No entanto, esse tipo de combustão, na realidade, sempre gera outros produtos em pequenas quantidades, como o monóxido de carbono $(\mathrm{CO})$ e os NOx (Óxidos de Nitrogênio) (GUZELLA; ONDER, 2010). 
O segundo tipo de reação observado é o de combustão não estequiométrica, onde a quantidade de oxigênio presente no processo de queima pode estar em concentrações maiores ou menores do que o necessário, aumentando a formação de outros produtos como os já citados (CO, NOx). Devido à quantidade de ar necessária para uma combustão completa variar muito de acordo com o tipo de combustível, utiliza-se como um parâmetro mais informativo o valor lambda $(\lambda)$, que é encontrado como sendo a razão ar-combustível atual dividida pela razão ar-combustível necessária para a combustão estequiométrica (equação 3).

$$
\lambda=\frac{A F R \text { real }}{A F R \text { ideal }}
$$

Para valores $\lambda$ maiores que 1 , a mistura é considerada podre, ou seja, com excesso de oxigênio. Para valores $\lambda$ menores que 1 a mistura é considerada rica (excesso de combustível). Com $\lambda$ igual a 1, a mistura está no ponto estequiométrico e assim há oxigênio suficiente para realizar a combustão completa (HEYWOOD, 1988).

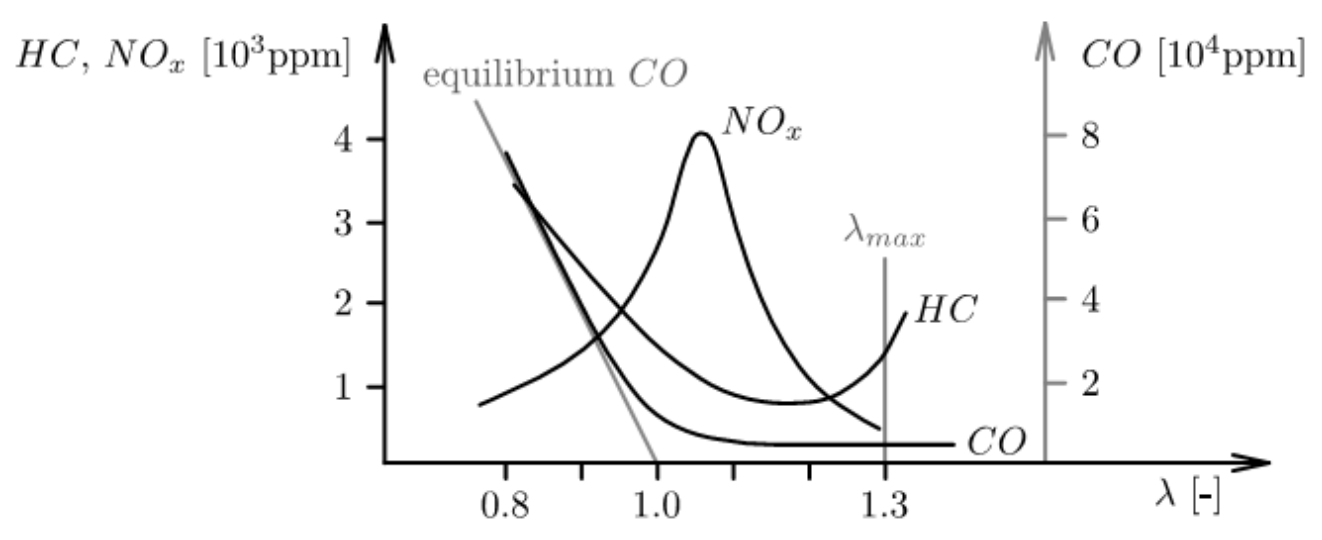

Figura 5 - Formação de poluentes.

Fonte: (GUZELLA, L.; ONDER, C. H., 2010)

Considerando que a quantidade de oxigênio presente na reação é menor que o necessário $(\lambda<1)$, não há oxigênio suficiente para oxidar todo o carbono e o hidrogênio do combustível para formação de água e $\mathrm{CO} 2$, formando assim grandes quantidades de $\mathrm{CO}$ e $\mathrm{HC}$ (hidrocarbonetos) devido à combustão incompleta (figura 5) (HEYWOOD, 1988; GUZELLA; ONDER, 2010).

Com a quantidade de oxigênio acima do necessário $(\lambda>1)$ a concentração de $\mathrm{HC}$ e CO não vai a zero devido a fatores como estocagem de hidrocarbonetos nos orifícios 
existentes entre pistão e cilindro durante o tempo de compressão e devido a falta de tempo para que toda a reação ocorra durante o tempo de expansão. Com $\lambda$ próximo do limite $(\lambda=$ 1.3) a queima se torna inconstante e a formação de HC é elevada devido a não haver a queima do combustível, o que também leva a não formação de CO.

Os óxidos de nitrogênio são outro tipo de poluentes formados durante o processo de combustão. São formados durante os picos de temperatura dentro do cilindro, tendo grande influência também da pressão dentro do cilindro e da quantidade de oxigênio presente na reação. A solução encontrada para reduzir a emissão desses poluentes é o uso de um conversor catalítico de três vias (TWC). Esse componente localizado no circuito de escape dos gases queimados tem a função de converter os $\mathrm{NOx}, \mathrm{HC}$ e $\mathrm{CO}$ em água e $\mathrm{CO}_{2}$. Com um sistema de controle que mantém o valor $\lambda$ em uma região muito próxima de 1 , esses catalisadores chegam a ter eficiência de conversão de 95\% (SCHÄFER, 1995).

É importante observar que a eficiência de conversão do TWC depende diretamente da relação ar-combustível, variações de $0.1 \%$ podem dobrar as emissões de poluentes. Durante regimes estáveis, são admitidas variações menores de $0.1 \%$ ao redor de $\lambda$ igual a 1 e de 2 a $3 \%$ durante transientes (NIELSEN; KIENCKE, 2005), o que indica a importância do sistema de controle da razão ar-combustível.

\subsection{Sistemas Eletrônicos de Ignição e Injeção de Combustível}

O sistema de injeção de combustível, geralmente, é formado pelos seguintes componentes:

- Bicos injetores: Atuadores responsáveis por realizar a liberação de combustível para produzir a mistura ar-combustível.

- Bomba de combustível: Componente que tem a função de manter a linha de combustível pressurizada.

- UCM ou ECU (Engine Control Unit): A unidade de controle do motor é responsável por realizar leituras dos sinais dos sensores, cálculos e por comandar os atuadores do motor.

- Sensores: Indicam para a UCM os estados atuais dos parâmetros utilizados para controle do sistema. 


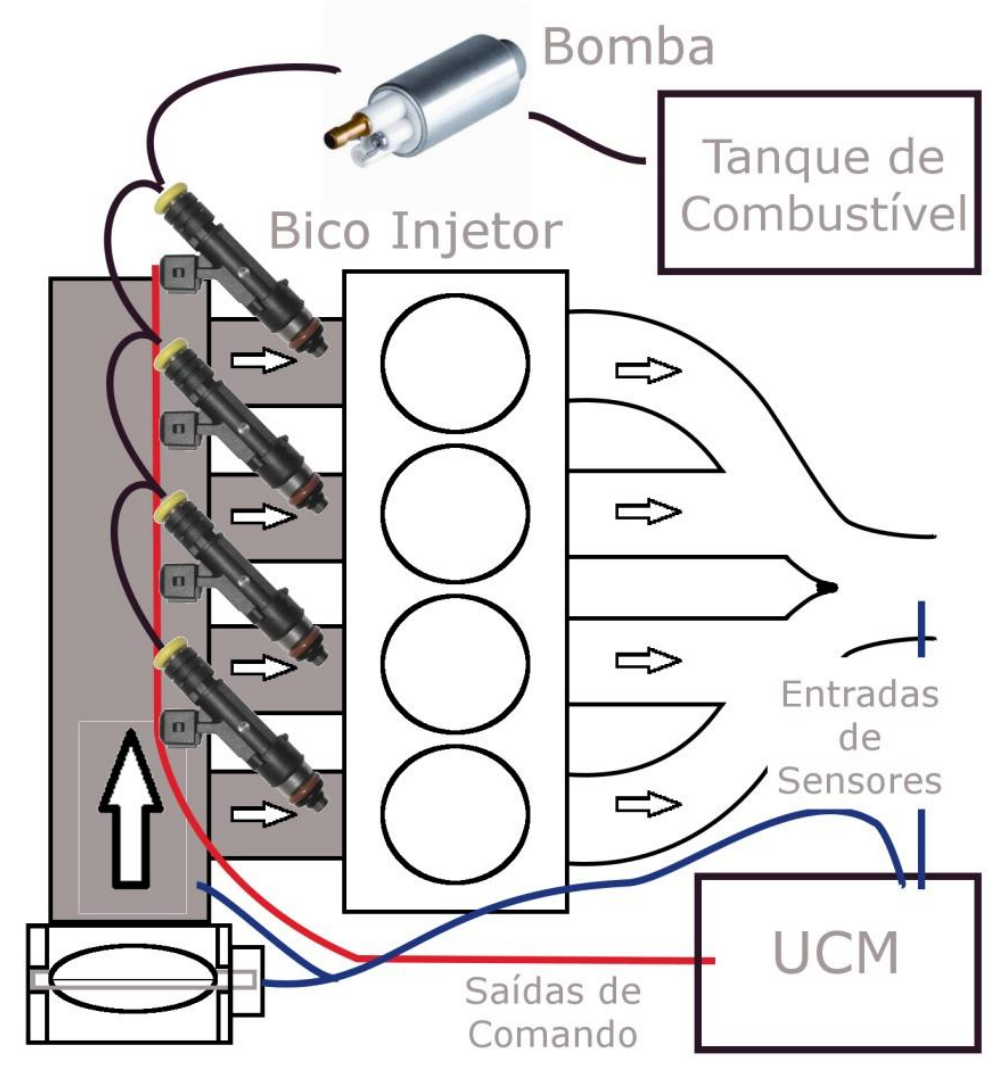

Figura 6 - Sistema de injeção eletrônica de combustível.

A figura 6 mostra um sistema básico de injeção de combustível em um motor de quatro cilindros com um bico injetor por cilindro (multiponto). A UCM recebe informações dos sensores e realiza os cálculos para comandar os bicos injetores, que são responsáveis por permitir a passagem do combustível para dentro do coletor de admissão.

O sistema de injeção de combustível pode utilizar um único injetor de combustível posicionado na entrada do coletor de admissão (sistema monoponto), no entanto, segundo Guzella e Onder (2010), esses sistemas apresentam certa dificuldade de controle devido a grandes efeitos de filmes de combustível no coletor de admissão e maiores atrasos de transporte.

Considerando os sistemas multiponto, é importante observar que a injeção de combustível durante o período em que a válvula de admissão está aberta pode aumentar a emissão de hidrocarbonetos, portanto, salvo algumas exceções, os sistemas terminam de injetar o combustível sempre antes da abertura da válvula de admissão (GUZELLA; ONDER, 2010). Em sistemas multiponto, são três as formas como os bicos injetores podem ser operados (ALBALADEJO, 2013). 
- Sequencialmente: Os bicos são comandados sequencialmente de acordo com a sequência de ciclos de admissão dos cilindros.

- Banco a banco: A injeção de combustível é realizada em dois cilindros simultaneamente, cada banco representa um conjunto de dois bicos injetores (motor de quatro cilindros). É uma técnica utilizada em motores que não utilizam sensor de fase.

- Full-group: Todos os bicos são comandados simultaneamente, geralmente é utilizada durante a partida do motor para garantir que todos os cilindros estão sendo alimentados.

Segundo Guzella e Onder (2010), as principais malhas de controle relacionadas ao sistema de injeção de combustível são:

- Malha de controle feedforward de injeção de combustível.

- Malha de feedback de controle da razão ar-combustível.

As duas malhas citadas realizam o controle da quantidade de combustível a ser injetada com base nos seguintes parâmetros (NIELSEN; KIENCKE, 2005):

- Fluxo de ar aspirado: Fluxo de ar passando pela válvula borboleta do motor, pode ser estimado ou lido diretamente com o auxílio de um sensor de fluxo. A estimação é realizada utilizando o sinal do sensor de posição da válvula borboleta e o valor de pressão dentro do coletor de admissão.

- Pressão dentro do coletor de admissão: Permite os cálculos de estimação de fluxo de massa de ar e indica o regime de carga do motor.

- Posição da válvula borboleta: Sensor responsável por indicar a posição atual da válvula borboleta. A derivada do sinal também é utilizada para fins de controle durante transientes.

- Velocidade angular do eixo do motor: Permite ao sistema de controle saber em que regime de velocidade o motor está operando.

- Temperaturas do motor e do ar ambiente: Parâmetros que influenciam diretamente nas estimações do fluxo de massa de ar e da taxa de vaporização do combustível dentro do coletor.

- Tensão da bateria: Importante para o controle de atuadores como bobinas e bicos injetores.

O sistema de ignição pode vir a utilizar os sinais dos mesmos sensores do sistema de injeção de combustível para estimar o avanço de ignição e o período de energização das bobinas de ignição. Outros sensores, como o sensor de detonação e o sensor de corrente iônica, podem ser utilizados como em Andersson (2002) e Campos e Reis Filho (2004). Na 
figura 7, é mostrado um sistema básico de ignição que utiliza duas bobinas para gerar as centelhas em um motor de quatro cilindros. Esse sistema em particular trabalha com o princípio de centelha perdida, que é chamado assim devido às velas de dois cilindros estarem ligadas a mesma bobina. Considerando que a sequência de queima dos cilindros é 1-3-4-2, e que os pares de cilindros são 1-4 e 2-3 (figura 7), observa-se na figura 3 que sempre que um cilindro do par está com o pistão próximo ao PMS no ciclo de compressão, o outro cilindro do par está no final do ciclo de escape, portanto, sempre que a bobina é comandada para gerar uma centelha, são geradas centelhas nas duas velas e a centelha que ocorre no cilindro que está no ciclo de escape é uma centelha perdida.

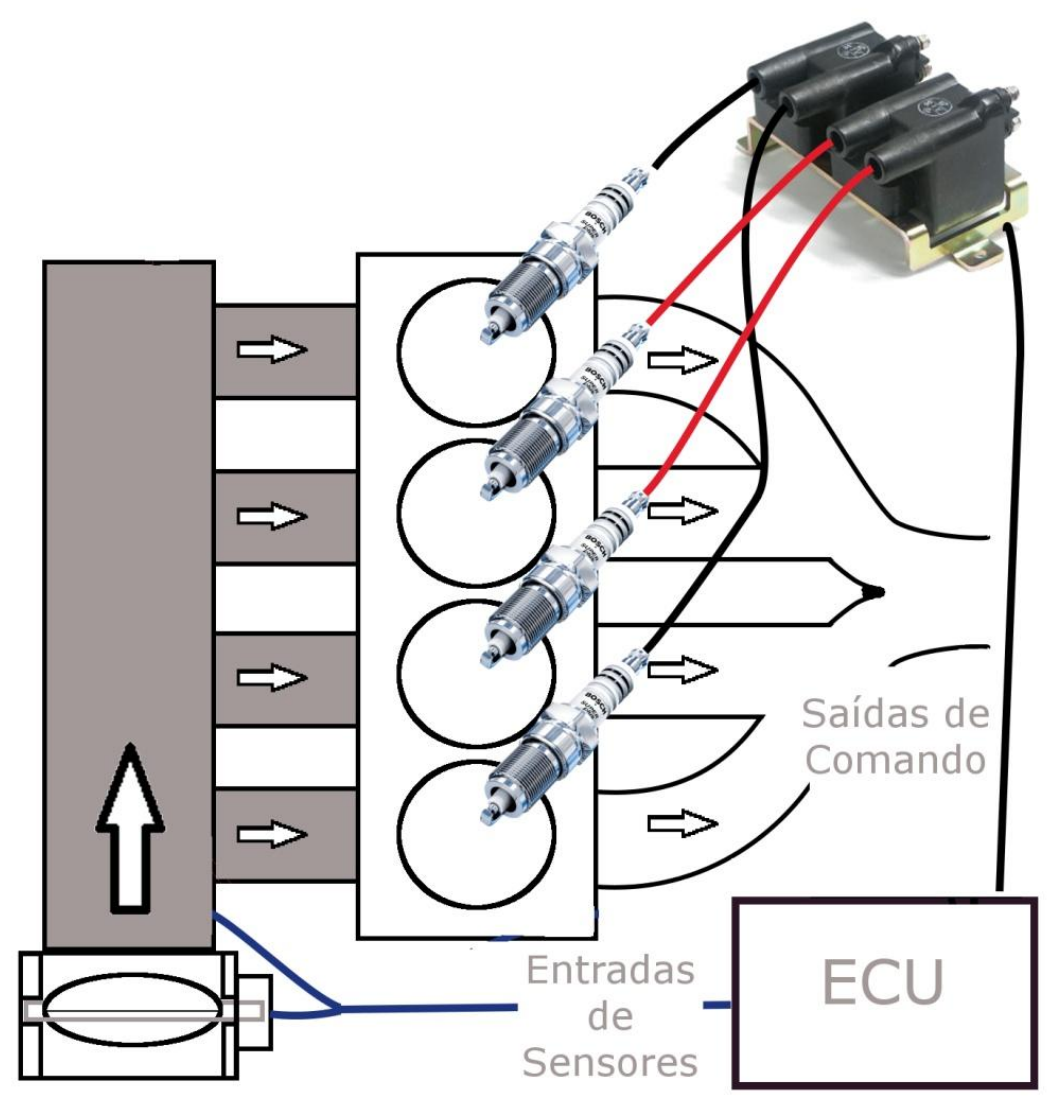

Figura 7 - Sistema básico de ignição com duas bobinas e centelha perdida.

As bobinas são comandadas pela UCM de maneira a gerar centelhas nas velas de ignição e iniciar a queima da mistura ar-combustível em uma posição ótima. A posição ótima em que a centelha deve ocorrer está em função principalmente da velocidade de queima e da velocidade angular do eixo do motor. O avanço de ignição pode ser limitado devido à mistura entrar em combustão quando partes mecânicas superaquecidas provocam a detonação dos 
gases de forma anormal, produzindo ondas de choque que podem vir a danificar o motor. A detonação gera um ruído característico que pode ser detectado pelo Sensor de Detonação (knock sensor). A UCM é responsável por identificar a detonação e realizar ajustes de avanço de ignição e de relação ar-combustível para evitar a detonação (CAMPOS; REIS FILHO, 2004). 


\section{Sensores}

\subsection{Posição angular do eixo do motor (Relutância variável e Hall)}

Os sensores de posição angular do eixo são posicionados de modo a medir as velocidades e posições dos eixos virabrequim e comando de válvulas. De acordo com Fleming (2001), os sensores de posição do eixo do motor podem ser de diversos tipos, sendo que os mais comumente utilizados são:

- Relutância variável: Geralmente são utilizados para medição de posição dos eixos virabrequim e comando de válvulas e são formados por uma bobina com o núcleo próximo a um campo magnético fixo (figura 8). Com a movimentação dos dentes de uma roda dentada próximas ao sensor, há a variação do fluxo magnético, o que acarreta na indução de uma tensão na bobina de acordo com a frequência com que os dentes passam próximos ao sensor.

- Efeito Hall: É utilizado para as mesmas funções do sensor de relutância variável, no entanto, realiza a medição direta da intensidade de fluxo magnético, o que permite que não haja perda de leitura em baixas velocidades ou com o eixo parado.

Os sensores de relutância variável apresentam as seguintes características:

- Sinal em corrente alternada com formato senoidal.

- Variação de tensão de pico de acordo com a velocidade do eixo do motor.

- Frequência do sinal de saída equivalente à frequência angular do eixo do motor multiplicado pela quantidade de dentes da roda dentada.

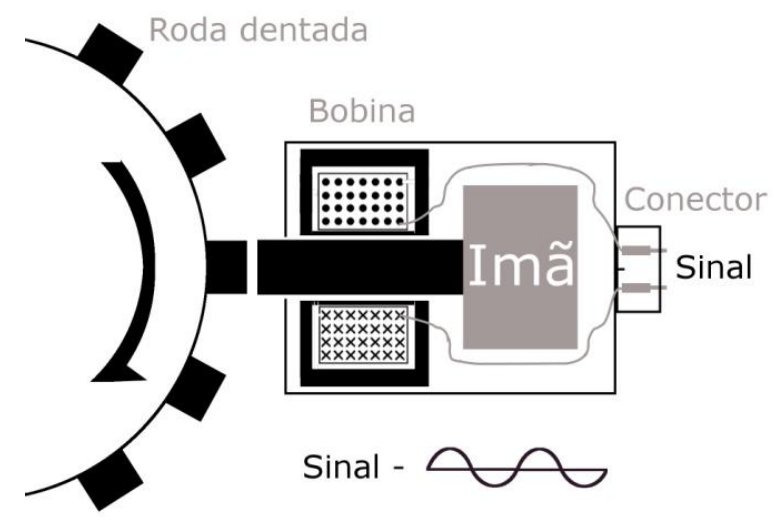

Figura 8 - Sensor de relutância magnética. 
Os sensores de efeito hall apresentam as seguintes características:

- Dependendo do sensor, o sinal pode ter o formato de uma onda quadrada ou apresentar tensão proporcional à intensidade do fluxo magnético que cruza o sensor.

- Necessita de alimentação externa.

- Tensão do sinal de saída limitada a tensão de alimentação.

- Frequência do sinal de saída equivalente à frequência angular do eixo do motor multiplicado pela quantidade de dentes da roda dentada.

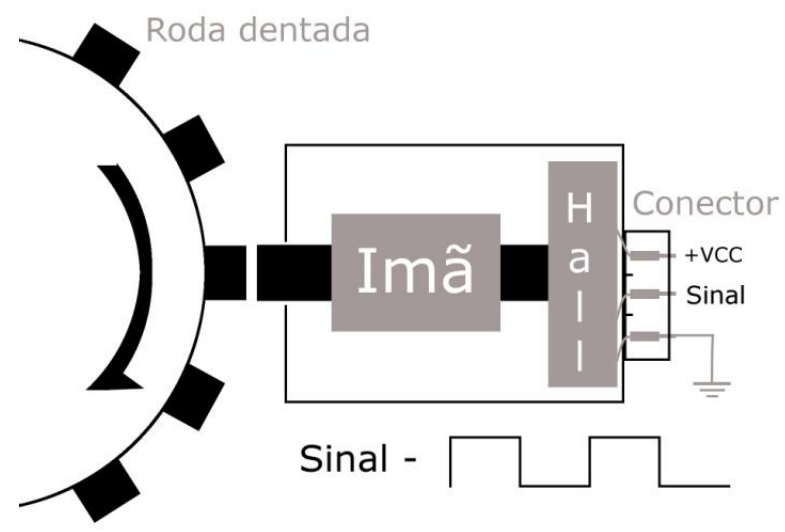

Figura 9 - Sensor de efeito Hall.

O efeito Hall se baseia na interação observada entre cargas elétricas e um campo magnético. O módulo, direção e sentido da força exercida sobre a carga elétrica estão diretamente relacionados com o valor da carga elétrica e também com as características do campo magnético que esta carga atravessa (FRADEN, 2010).

Na figura 10, é apresentado um esquema simplificado de um sensor de efeito Hall. Ao atravessar o campo magnético, o elétron sofre uma força que o empurra para uma das extremidades do material condutor. Considerando um fluxo constante de corrente pelo condutor, uma das extremidades apresenta maior densidade de cargas negativas, o que produz uma diferença de potencial entre os lados do condutor. 


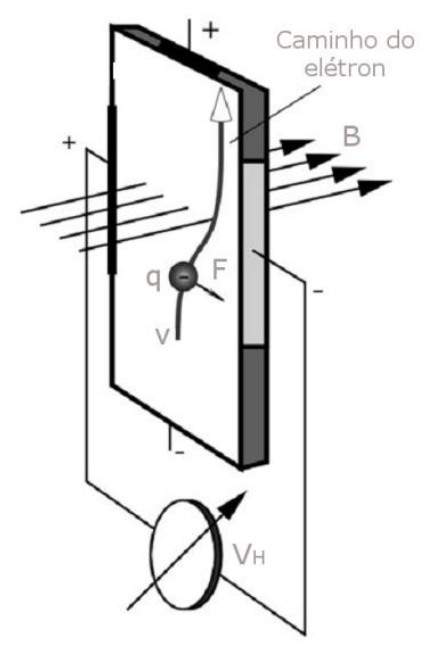

Figura 10 - Sensor de efeito Hall simplificado. Fonte: Adaptado de Fraden, 2010.

A diferença de potencial está diretamente relacionada com a intensidade do campo magnético que atravessa o material condutor. Essa tensão é amplificada e pode ser utilizada tanto no formato analógico como pode ser tratada e transformada em um sinal digital.

\subsection{Pressão do ar no coletor de admissão (MAP)}

Os sensores MAP (Manifold Absolute Pressure) são ligados diretamente aos gases dentro do coletor de admissão, com o intuito de medir a pressão absoluta desses. Os sensores podem ser instalados tanto diretamente no coletor de admissão como ligados por mangueiras e instalados no cofre do motor ou até dentro da UCM. Esses sensores permitem que a central eletrônica tenha, em conjunto com outros sensores, a possibilidade de estimar o regime de carga em que o motor se encontra e a quantidade de massa de ar que está sendo admitida. 


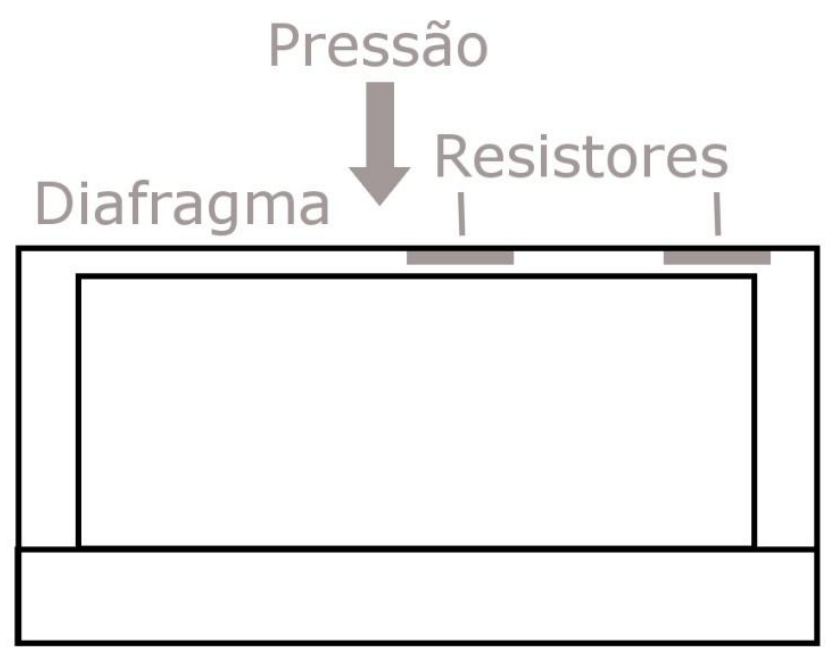

Figura 11 - Sensor de pressão piezoresistivo.

Como observado por Albaladejo (2013), os sensores atualmente mais utilizados são baseados na tecnologia piezoresistiva. De acordo com Fraden (2010), esses sensores são constituídos por um diafragma feito de silício, com piezoresistores produzidos com o depósito de impurezas na superfície do cristal de silício (figura 11). A corrente por esses resistores varia de acordo com a deformação e pressão sobre o cristal.

\subsection{Sensor de oxigênio (Sonda Lambda)}

Os sensores de oxigênio são de grande importância para os controles de emissões de gases poluentes de motores de combustão interna. Eles indicam qual a quantidade de oxigênio presente nos gases queimados para que a unidade de controle saiba se a relação arcombustível está no ponto estequiométrico.

Geralmente, observam-se os seguintes tipos de sensores de oxigênio nos veículos:

- Banda Estreita (Narrow Band).

- Banda Larga (Wide Band).

O sensor de banda estreita apresenta uma comutação de nível de tensão de saída dependendo se a mistura de ar e combustível está rica $(\lambda<1)$ ou pobre $(\lambda>1)$, como pode ser visto na figura 12 . 


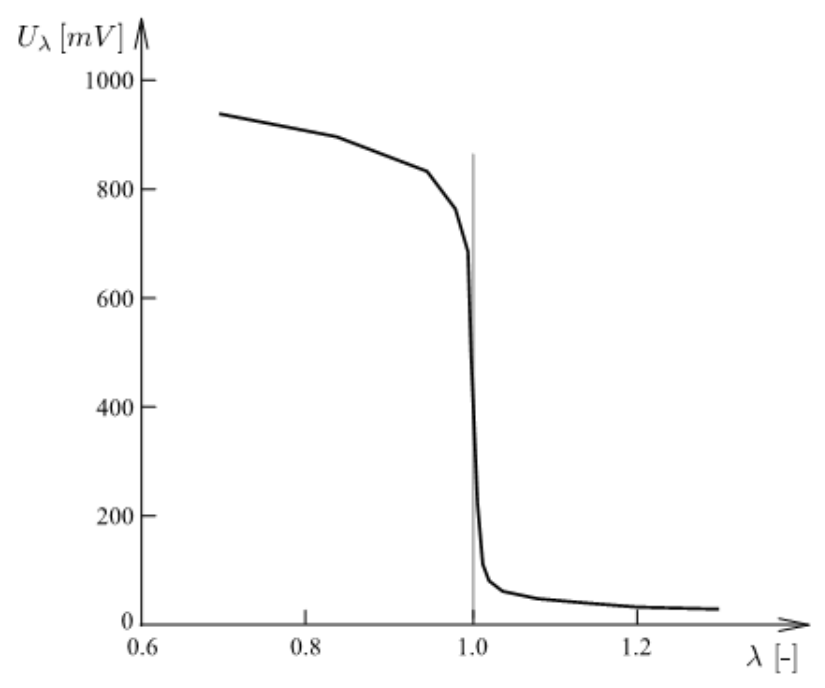

Figura 12 - Saída do sensor de oxigênio de banda estreita Fonte: (GUZELLA, L.; ONDER, C. H., 2010).

Os sensores de banda larga apresentam tensão de saída linear em função da relação arcombustível (figura 13), ou seja, é possível saber quão rica ou pobre está a mistura admitida e queimada pelo motor.

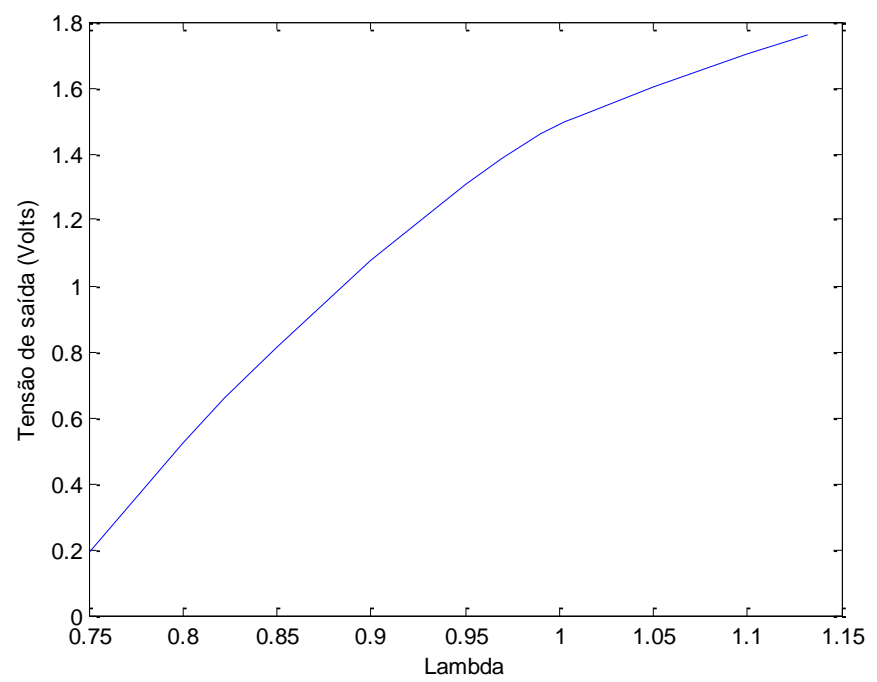

Figura 13 - Saída do sensor de oxigênio de banda larga. Fonte: (BOSCH, 2011) 


\subsection{Temperatura (MAT, IAT e CLT)}

Os sensores de temperatura permitem à UCM realizar os cálculos de densidade do ar para que seja possível a estimação da quantidade de combustível a ser injetada. Além da estimação da quantidade de combustível, também são realizadas muitas outras correções, como exemplo, as correções de ponto de ignição em função da temperatura do motor e correções de quantidade de combustível injetada. Os sensores de temperatura do ar entrando no motor e do ar dentro do coletor de admissão (figura 14) são chamados respectivamente de IAT (Intake Air Temperature) e MAT (Manifold Air Temperature).

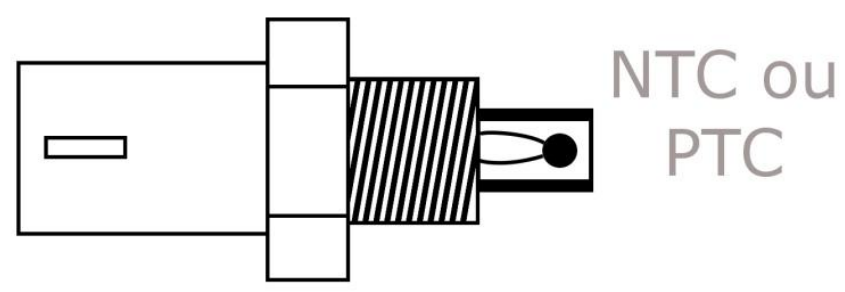

Figura 14 - Sensor de temperatura do ar (IAT).

Para monitoramento da temperatura do motor, é realizada a medição da temperatura do líquido de arrefecimento. A medição é feita com um sensor muito similar ao sensor de temperatura do ar e é chamado de CLT (Coolant Liquid Temperature) (figura 15). Os elementos sensores podem ser resistores NTC (Negative Temperature Coefficient) ou PTC (Positive Temperature Coefficient) que são resistores que variam sua resistência de acordo com a temperatura.

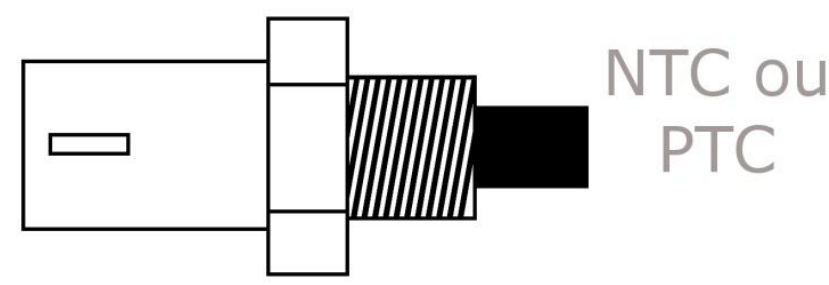

Figura 15 - Sensor de temperatura do liquido de arrefecimento (CLT).

Como mostrado nas figuras 14 e 15, os sensores apresentam encapsulamentos diferentes de acordo com o material do qual eles vão medir a temperatura. No caso dos 
sensores de temperatura do fluido refrigerante, geralmente é utilizado um encapsulamento metálico para proteção do sensor, enquanto que, nos sensores de temperatura do ar, o sensor pode ou não ficar mais exposto e apresentar constantes de tempo da mesma ordem ou menores (BOSCH, 2015c). Na figura 16 está representada a curva característica de um sensor de temperatura de ar do tipo NTC.

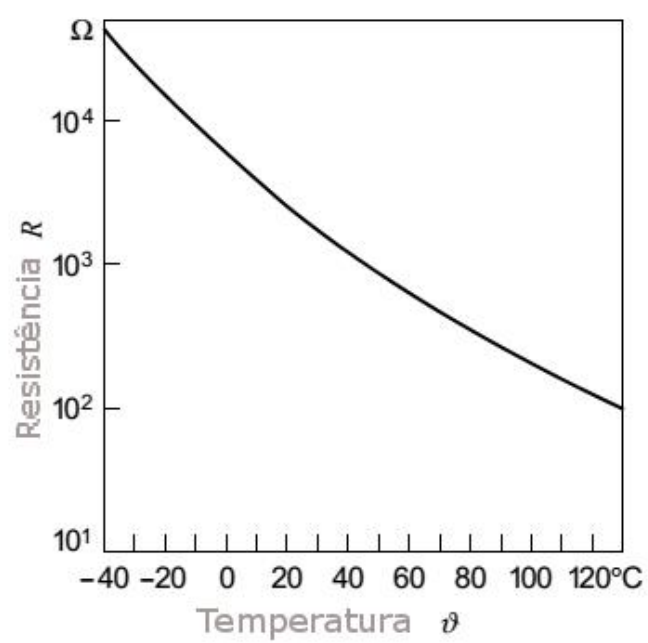

Figura 16 - Curva característica do sensor NTC. Fonte: (BOSCH, 2015c)

\subsection{Posição da válvula borboleta (TPS)}

O sensor de posição da válvula borboleta indica à UCM as variações na posição angular do eixo da válvula de controle de entrada de ar do motor. A abertura da válvula pode ser dada tanto diretamente pelo motorista, como pelo servomecanismo que aciona a válvula, no caso dos sistemas com borboleta eletrônica. 


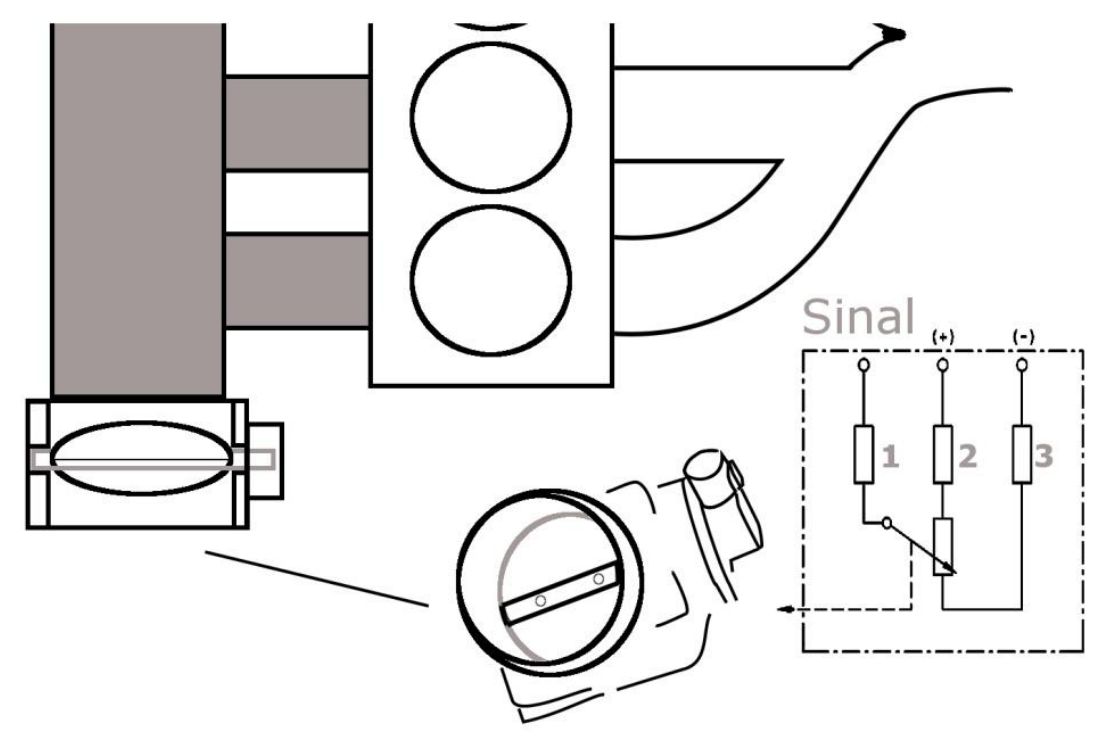

Figura 17 - Corpo de borboleta com sensor de posição da válvula.

O sinal desse sensor pode ser utilizado como parâmetro de controle em técnicas feedforward para cálculos de valores como quantidade de combustível ideal, ponto de ignição e estimação de massa de ar sendo admitida tanto em regime estável como durante transientes. No caso de sistemas com borboleta eletrônica, são utilizados como parte do servomecanismo de acionamento da válvula, sendo que, nesse caso, a UCM é responsável pelo comando de abertura. O sensor é composto por resistores conectados a um potenciômetro que é comandado pelo eixo da válvula borboleta. Os resistores 1,2 e 3 conectados ao potenciômetro (figura 17) são utilizados para proteção. O sensor apresenta resistência proporcional ao ângulo de abertura da válvula.

\subsection{Sensor de detonação}

Segundo Filardi (2013), a detecção da detonação pode ser realizada utilizando técnicas como: medições de pressão dentro da câmara de combustão, com o uso de sensores de corrente iônica, com métodos baseados em transferência de calor e medindo as vibrações do bloco do motor. Ainda de acordo com esse autor, geralmente, devido a restrições econômicas, são utilizados acelerômetros montados no bloco dos motores para medir as vibrações resultantes da detonação. 


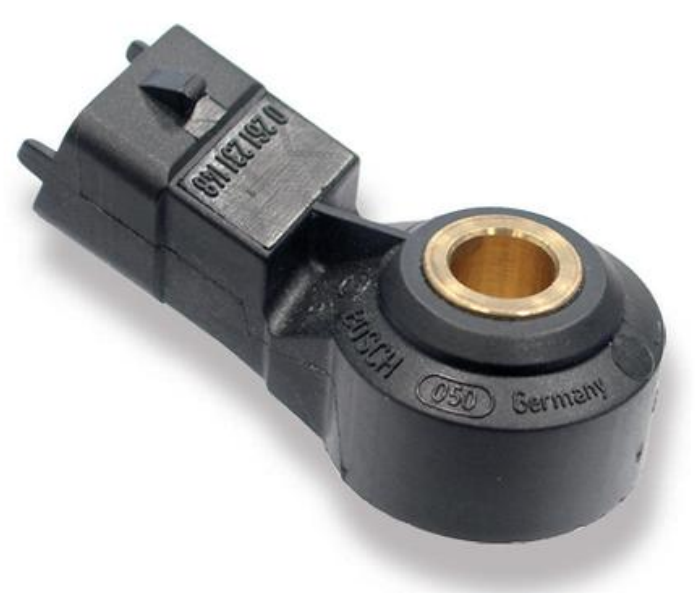

Figura 18 - Sensor de detonação.

Fonte: (BOSCH, 2016a)

O acelerômetro utilizado, também chamado de sensor de detonação (figura 18), detecta as vibrações estruturais geradas por combustões não controladas ou anormais. Internamente, o sensor é constituído de uma massa conectada a um sensor piezocerâmico, que por sua vez está conectado ao bloco do motor. Devido à inércia da massa, sempre que há uma vibração do bloco, uma pressão é exercida sobre o material piezocerâmico, que gera picos de tensões que estão diretamente relacionadas à aceleração que o sensor sofre durante o movimento do bloco do motor (BOSCH, 2016).

\subsection{Sensor de fluxo de massa de ar (MAF)}

Em algumas técnicas de controle feedforward de injeção de combustível, são aplicados sensores de medição de fluxo de massa de ar (MAF) em conjunto com observadores de estados e observadores de entradas para estimar, da melhor maneira possível, o fluxo de massa de ar entrando no motor (ASHOK; ASHOK; RAMESH KUMAR, 2016). 

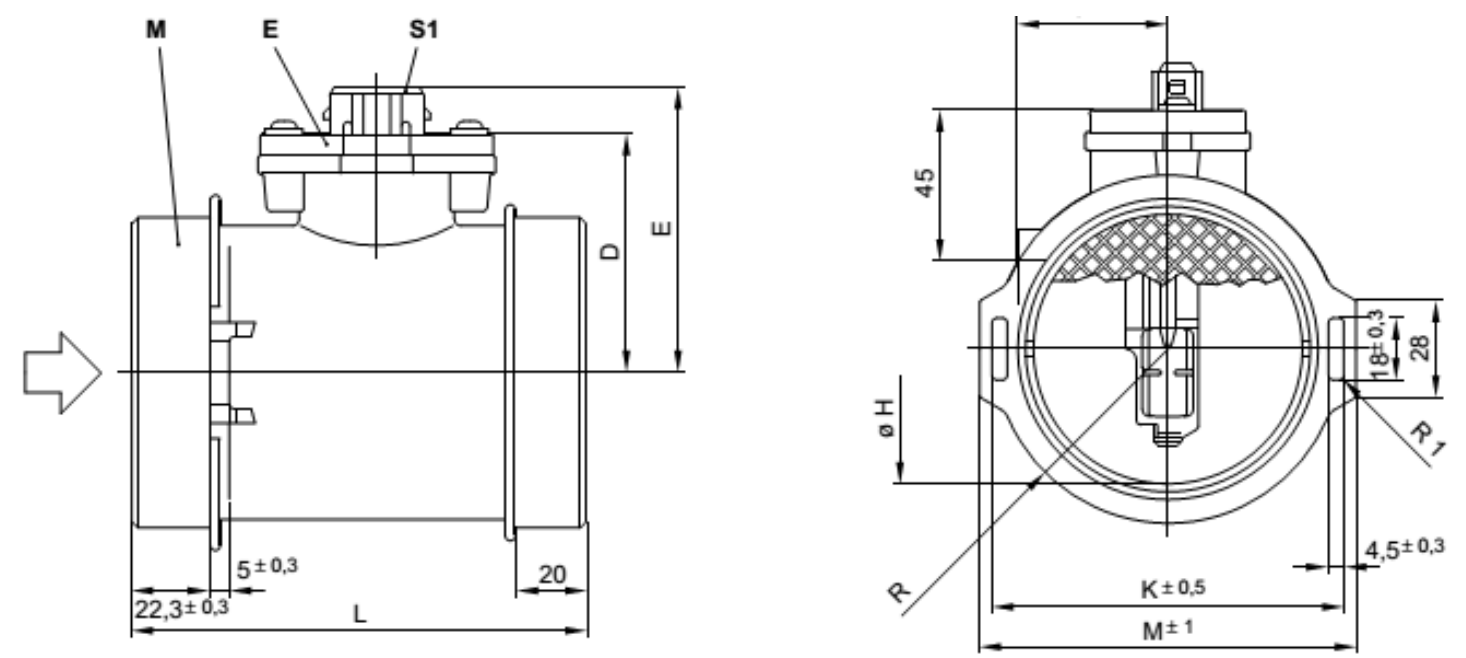

Figura 19 - Sensor de Fluxo de massa de Ar (MAF). Fonte: (BOSCH, 2015a)

O sensor observado na figura 19 tem internamente um anemômetro de fio quente. Esse sensor é composto por um fio ou filme de platina aquecido a temperatura constante e conectado termicamente ao filme de platina há um termistor (BOSCH, 2015a). De acordo com o fluxo de massa de ar que passa pelo filme aquecido, há a variação de temperatura do ar que, por sua vez, produz a variação de temperatura do termistor. Dessa forma a resistência do termistor fica em função do fluxo de massa de ar, possibilitando a leitura desse parâmetro (ALBALADEJO, 2013). 


\section{$4 \quad$ Atuadores}

\subsection{Bicos injetores}

Os bicos injetores são os atuadores responsáveis por permitir a passagem de combustível da linha de combustível pressurizada para o coletor de admissão em motores com injeção na porta da válvula de admissão, e para dentro do cilindro do motor, no caso dos motores com injeção direta de combustível.

Possuem uma válvula eletromecânica que é comandada pela UCM. Quando aberta, sua vazão é constante para pressão de combustível constante, e a quantidade de combustível injetada é dada de acordo com o período durante o qual a válvula fica aberta. Na figura 20, pode-se observar em corte a estrutura interna simplificada de um bico injetor para injeção de combustível no coletor de admissão.

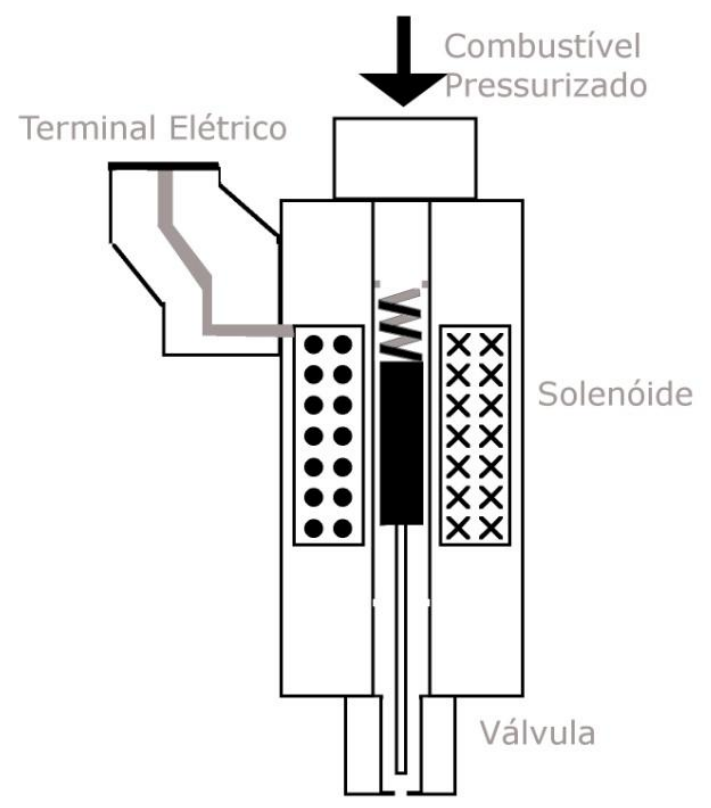

Figura 20 - Bico injetor de combustível

Durante o período em que o bico injetor deve ser mantido aberto, a bobina do solenoide é mantida alimentada, o que faz com que o material ferromagnético ligado à agulha da válvula seja puxado para cima e vença a força da mola. Com a agulha puxada, como visto 
na figura 20, o combustível pressurizado tem a possibilidade de passar pelo bico injetor e sair pelo furo que estava fechado pela agulha (ANDO, R.; KOIZUMI, M.; ISHIKAWA, T., 2001).

\subsection{Bobinas de ignição}

As bobinas de ignição são construídas como um transformador elevador de tensão. A alta tensão induzida no secundário do transformador é utilizada para romper a barreira de potencial entre os eletrodos da vela e dar início à chama dentro do cilindro do motor.

São comandadas pela UCM através de um driver que pode estar dentro da própria UCM, em um módulo especifico fora da UCM ou junto à bobina (FAIRCHILD, 2014). O papel da UCM é calcular o momento ideal para inicio da energização da bobina de forma que o final da energização da bobina coincida com o momento em que a centelha deve ser produzida dentro do cilindro.

\section{Alta tensão}

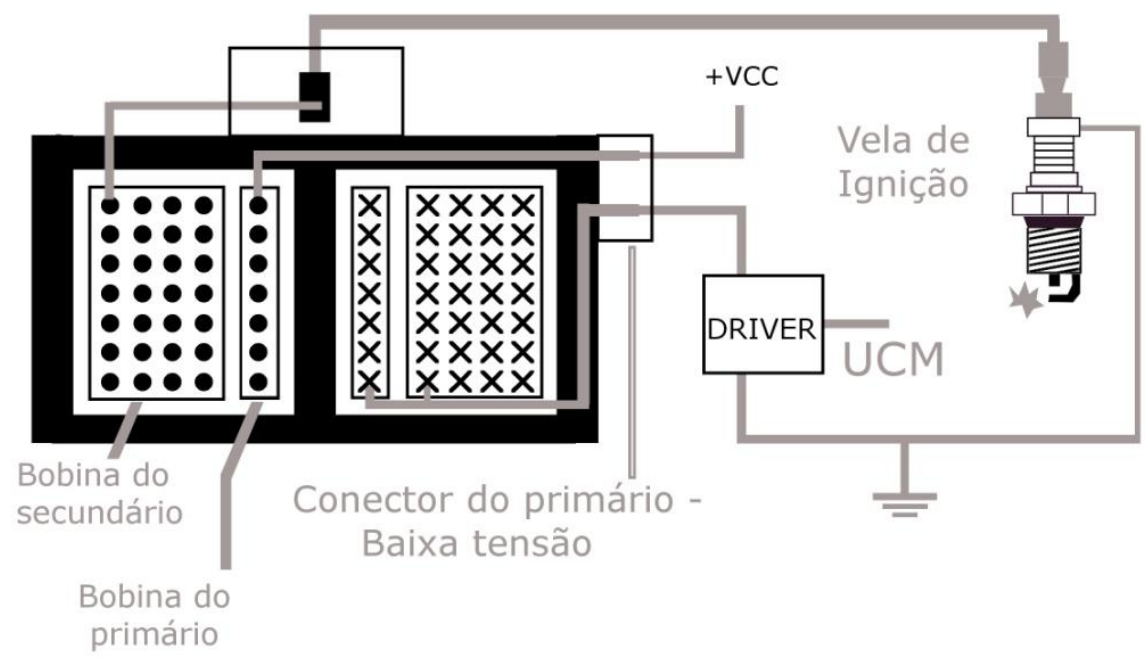

Figura 21 - Bobina de ignição - Circuito

O driver é responsável por aterrar a bobina do primário, possibilitando a corrente pela bobina e consequentemente a energização da mesma (figura 21). Com a bobina energizada, o driver interrompe a corrente no primário, causando a indução de alta tensão no secundário (NING CHEN; YUN ZHANG, 2010). 


\subsection{Borboleta Eletrônica e Atuador de Marcha lenta}

Para o controle de fluxo de massa de ar para dentro do motor, são utilizadas válvulas que podem ser construídas utilizando solenoides (figura 22), motores de passo ou servomecanismos (figura 23). Os atuadores, como visto na figura 22, são utilizados em sistemas onde a válvula borboleta é comandada via cabo. Esses atuadores trabalham permitindo a passagem de ar para dentro do motor mesmo que a válvula borboleta esteja completamente fechada (MILHOR, C. E. 2002).

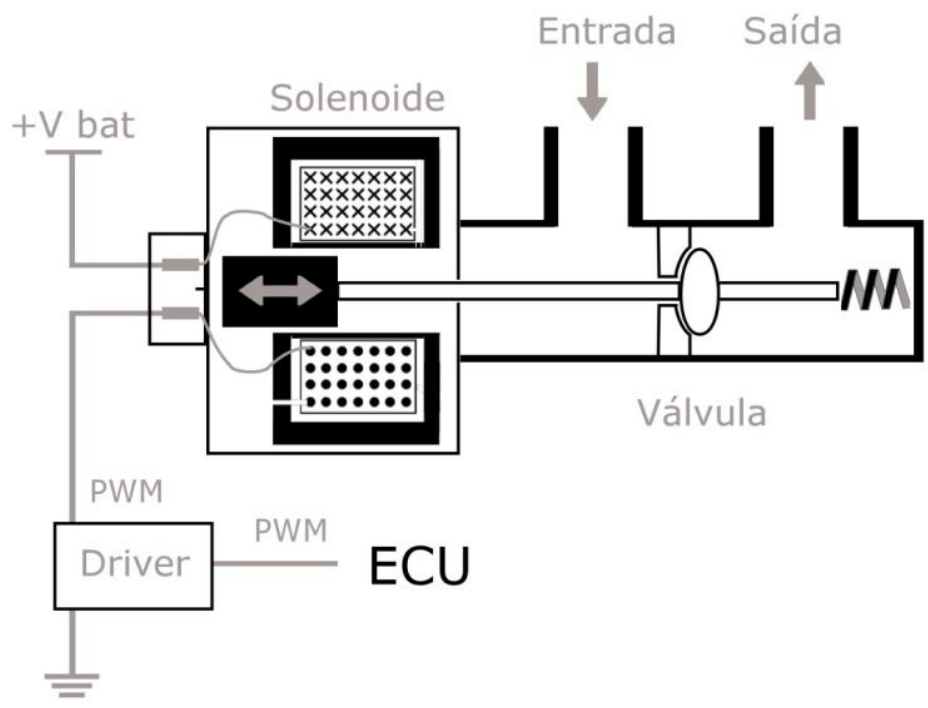

Figura 22 - Atuador de marcha lenta.

Usualmente, os sistemas que utilizam servomecanismos possuem somente uma válvula e operam sem cabos de comando da válvula borboleta. O controle desses sistemas é realizado pela UCM. Para isso, é utilizado um sensor de posição do pedal do acelerador e um sensor de posição da válvula borboleta (ZAVALA, J. C.; STEWART, P.; FLEMING, P. J., 2002). 


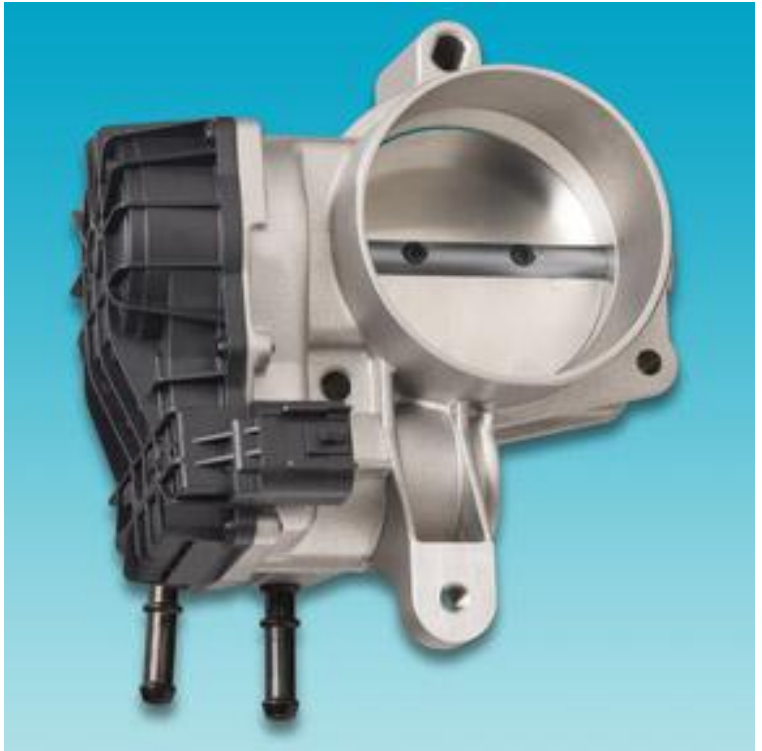

Figura 23 - Corpo de borboleta com servomecanismo (borboleta eletrônica). Fonte: (DELPHI, 2016) 


\section{$5 \quad$ Malhas de Controle}

Nos motores de combustão interna modernos há uma tendência de aumento da quantidade de atuadores com o propósito de aumentar a eficiência dos sistemas. Essas tecnologias provocam o aumento das malhas de controle e diretamente influenciam na complexidade dos controladores (MALACZYNSKY et al, 2010). Entre estas tecnologias podem-se citar o EGR (Exhaust Gas Recirculation) e o VVT (Variable Valve Timing). No entanto, todos os sistemas apresentam malhas básicas de controle que são consideradas as mais importantes por serem a base para a operação dos outros sistemas. Segundo Guzella e Onder (2010) e Yildiz et al (2009), essas malhas são:

- Malha Feedforward de injeção de combustível.

- Malha Feedback de razão Ar-Combustível.

- Malha Feedforward de avanço de ignição.

- Malha de Controle de detonação.

\subsection{Malha Feedforward de injeção de combustível}

Uma boa estimativa do fluxo de massa de ar é muito importante para que seja possível formar uma mistura o mais próximo possível do ponto estequiométrico. Para realizar essa função, geralmente, são utilizadas as técnicas de estimação e de medição do fluxo de massa de ar. Geralmente, a técnica de estimação utilizada é chamada de speed density (ASHOK; ASHOK; RAMESH KUMAR, 2016), para os cálculos é utilizada a densidade do ar dentro do coletor de admissão, o valor de eficiência volumétrica do motor e a velocidade do eixo (equação 4) (HENDRICKS; SORENSON, 1990).

$$
\dot{m}_{c}=\rho\left(t, p_{c}\right) \cdot \eta\left(p_{c}, \omega_{e}\right) \cdot \frac{V_{d}}{N} \cdot \frac{\omega_{e}(t)}{2 \pi}
$$

Onde:

$p_{c}=$ Pressão dentro do coletor de admissão. 
$\dot{m}_{c}=$ Fluxo de massa de ar passando pelo coletor de admissão.

$\rho\left(t, p_{c}\right)=$ Densidade do ar dentro do coletor de admissão em função da temperatura e da pressão.

$\eta\left(p_{c}, \omega_{e}\right)=$ Eficiência volumétrica em função da pressão do ar e da velocidade angular do eixo do motor.

$V_{d}=$ Capacidade volumétrica do motor.

$\omega_{e}=$ Velocidade angular do eixo virabrequim.

$\mathrm{N}=$ Número de voltas por ciclo (igual a 1 para motores dois tempos e igual a 2 para motores quatro tempos).

A eficiência volumétrica é um dos parâmetros principais na técnica speed density, pois indica o quanto o sistema real difere do sistema teórico. Geralmente, esse valor é modelado com o uso de tabelas estáticas de duas dimensões, com eixos de pressão (MAP) e velocidade do motor em rotações por segundo. Em função de cada regime de pressão e velocidade, a tabela indica qual é a eficiência volumétrica do motor. Essas tabelas são obtidas com experimentos nos motores ou com uso de modelos muito precisos dos sistemas mecânicos (ASHOK; ASHOK; RAMESH KUMAR, 2016). Além das tabelas estáticas, há trabalhos voltados a descrever a eficiência volumétrica com o uso de outras técnicas, como exemplo, em Malaczynski (2010) e Hu Chun-Ming e Ju Bing (2010), são utilizadas redes neurais artificiais para substituir as tabelas.

A segunda técnica utilizada para estimar o fluxo de massa de ar utiliza diretamente o sensor de massa de ar (MAF) para os cálculos de massa de combustível a ser injetada no motor. As duas técnicas citadas apresentam problemas na estimação do fluxo de ar. Os sensores MAF realizam medições precisas durante regimes estáveis de funcionamento do motor. No entanto, durante transientes, as leituras não são precisas e ocorrem atrasos de transporte do sistema. Já no caso do sistema speed density, observa-se que os valores de eficiência volumétrica podem variar durante o período de vida útil do sistema, devido a desgastes e impurezas, o que causa erros de estimação (GUZELLA; ONDER, 2010; ASHOK; ASHOK; RAMESH KUMAR, 2016). A figura 24 mostra um sistema de controle Feedforward que utiliza um estimador de massa de ar que tem os sinais dos sensores de velocidade do motor e de fluxo de massa de ar (MAF) como parâmetros de estimação. 


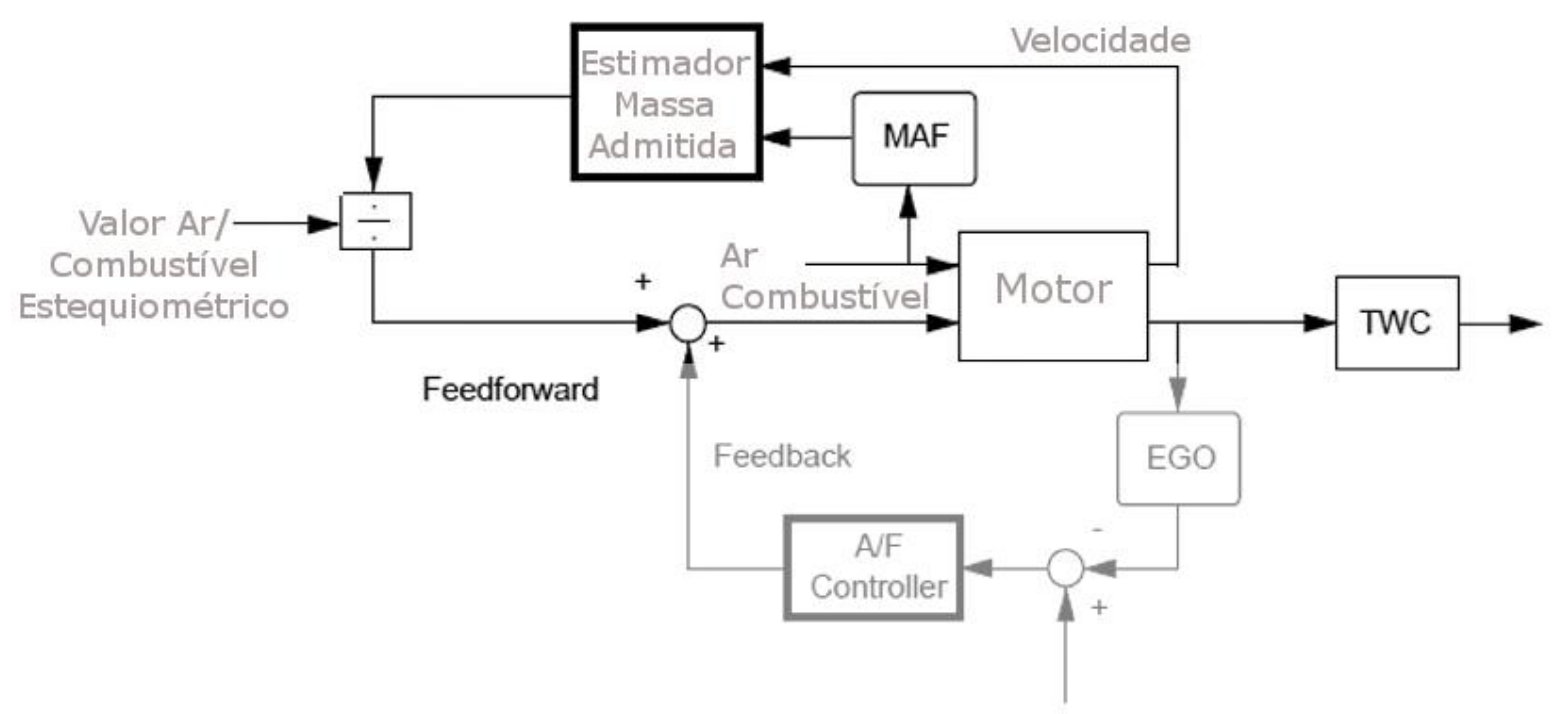

Figura 24 - Esquema de controle Feedforward de combustível. Fonte: Adaptado de Ashok, Ashok e Ramesh Kumar, 2016.

Outro fator importante nos cálculos de quantidade de combustível a ser injetada é o efeito de filme de combustível. Esse efeito ocorre quando o combustível injetado fica preso em um filme de combustível nas paredes do coletor de admissão. Durante transientes, são gerados atrasos na entrada do combustível para dentro do cilindro do motor, o que pode produzir misturas podres durante o aumento do fluxo de massa de ar. No caso de transientes em que o fluxo de massa de ar é reduzido, a mistura pode ficar rica devido ao excesso de combustível no filme de combustível (YI-HU WU; ZHI-XIANG HOU; HUANCHUN GONG, 2010).

Para solucionar esse problema, são utilizadas técnicas de estimação do fluxo de combustível necessário para que a quantidade correta de combustível faça parte da mistura. Uma maneira de realizar essa estimação é com o uso de modelos de Hendricks e Aquino como comentado em Yi-hu Wu (2008).

\subsection{Malha Feedback de razão Ar-Combustível}

O loop de realimentação (feedback) de razão ar-combustível é responsável por manter o valor $\lambda$ o mais próximo possível de 1 para que a eficiência de conversão do catalisador seja a maior possível. Esse loop realiza a compensação dos erros de estimação do loop 
feedforward utilizando o sinal do sensor de oxigênio (YILDIZ et al, 2009). Seria interessante a utilização da realimentação de concentrações dos principais gases emitidos pelo motor, pois a UCM teria mais informações para controle. No entanto, observa-se que isso é inviável, devido à complexidade de introdução desses sensores nos sistemas atuais (PUJATTI, 2007).

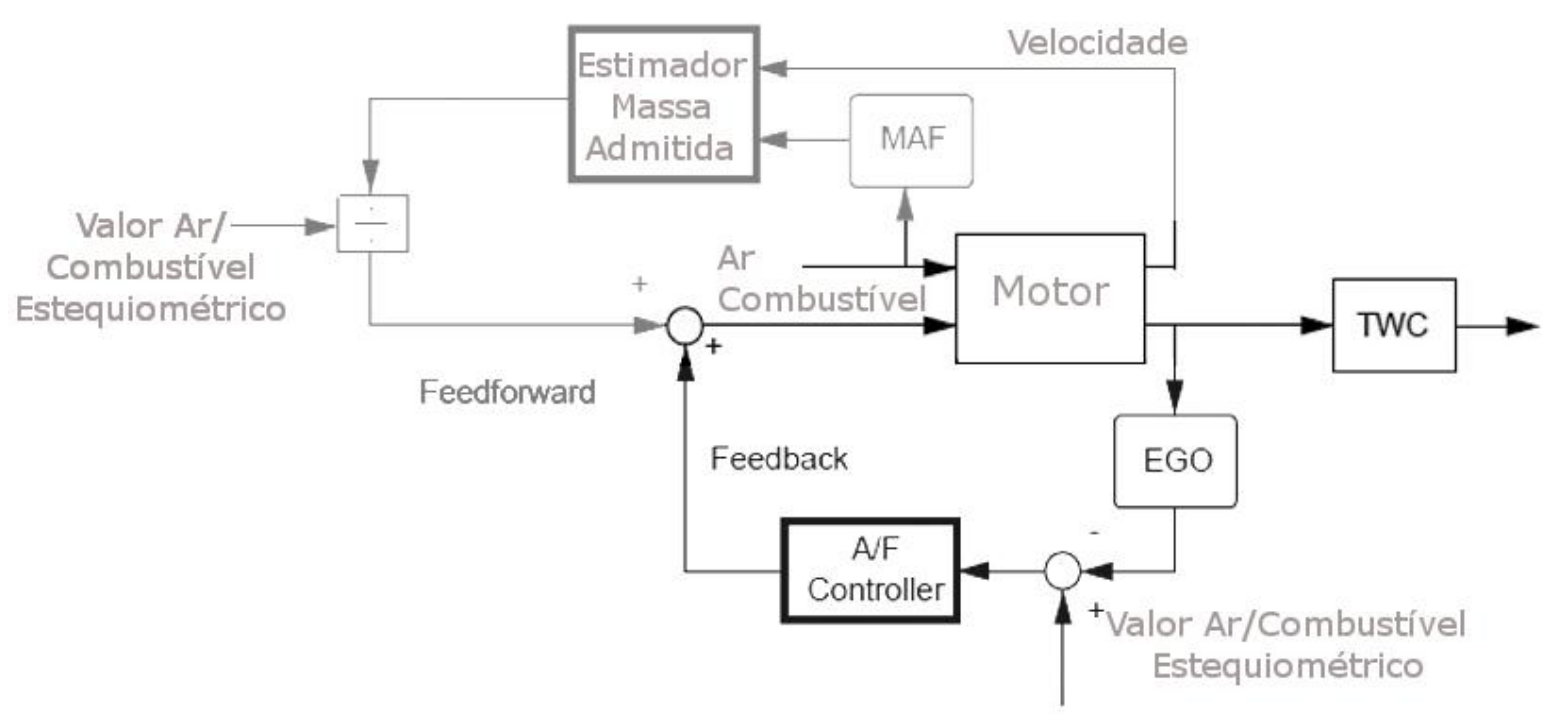

Figura 25 - Esquema de controle feedback de razão Ar-Combustível. Fonte: Adaptado de Ashok, Ashok e Ramesh Kumar, 2016.

A figura 25 apresenta um esquema básico de controle feedback de razão arcombustível em que o valor de erro a ser injetado no controlador é gerado utilizando-se o sinal do sensor de oxigênio e o setpoint de razão ar-combustível. Como observado em Hendricks e Luther (2001), muitas técnicas de controle foram propostas e empregadas para essa função. No entanto, segundo Ashok, Ashok e Ramesh Kumar (2016), a maior parte dos sistemas em produção utilizam controladores PID (Proporcional-Integral-Derivativo) com escalonamento de ganhos devido à simplicidade da técnica.

\subsection{Malha Feedforward de avanço de ignição}

Geralmente, o loop de controle feedforward para o sistema de ignição é muito similar ao loop do sistema de combustível. São utilizadas tabelas estáticas que indicam qual é o melhor ponto de ignição a ser utilizado por regime de operação do motor. Esses valores são 
estocados em tabelas de até duas dimensões que ficam em função de variáveis como pressão dentro do coletor de admissão, velocidade do motor e temperatura do motor (GUZELLA; ONDER, 2010). A figura 26 mostra um gráfico com a representação dos valores de uma tabela.

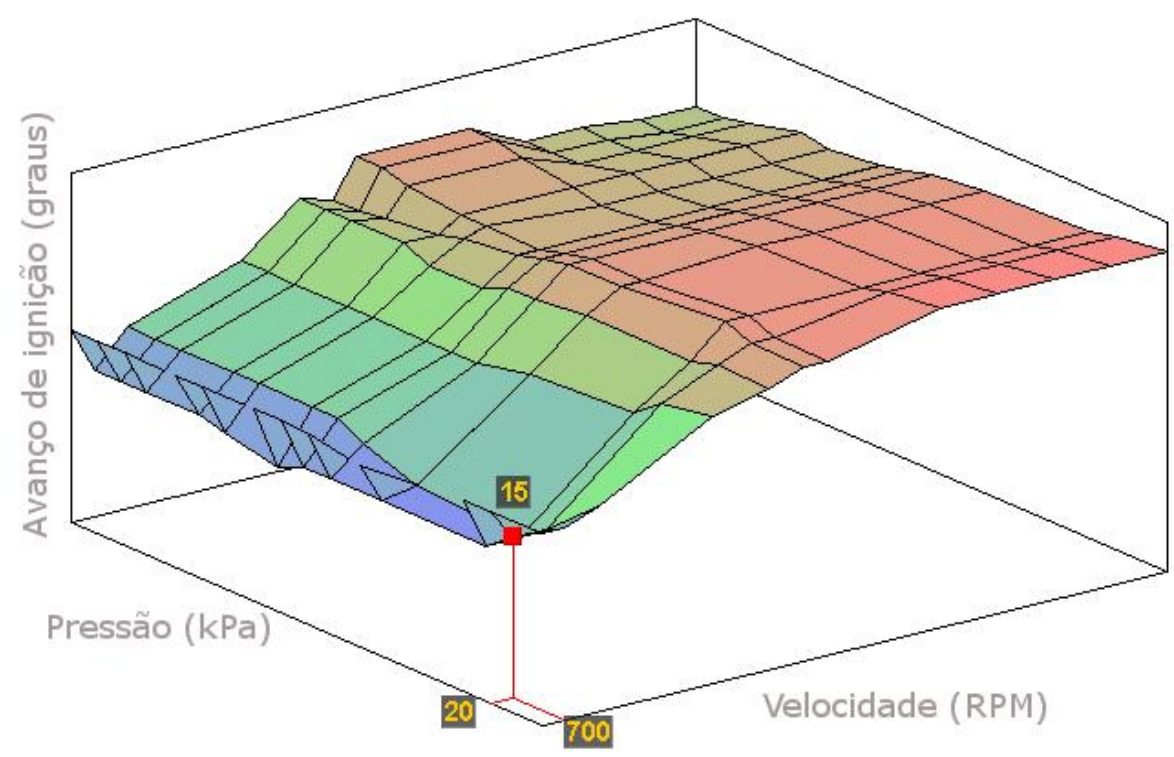

Figura 26 - Mapa de avanço do ponto de ignição.

O avanço do ponto de ignição ideal está relacionado com o ponto de maior pressão (PPP - Peak Pressure Position) dentro do cilindro durante a combustão. O PPP é dado em graus e é interessante que ocorra próximo a $15^{\circ}$ depois do PMS, gerando assim a maior eficiência de conversão de energia (MAGNUSSON, 2007).

\subsection{Malha de Controle de Detonação}

A detonação é um fenômeno que ocorre devido à queima não controlada do combustível dentro da câmara de combustão. Essa queima anormal provoca ondas de choque quando as frentes de chama da queima anormal se encontram com a frente de chama gerada pela centelha da vela de ignição e podem produzir danos significantes ao motor (NIELSEN; KIENCKE, 2005). A ECU monitora o sinal de detonação e toma ações de ajuste de ignição e de injeção de combustível para reduzir os efeitos de detonação. O sinal de detonação é 
medido por um sensor piezoelétrico posicionado no bloco do motor (CAMPOS; REIS FILHO, 2004).

Segundo Nielsen e Kiencke (2005), o processo de detonação depende diretamente de fatores como pressão do ar sendo admitido, temperatura do ar e qualidade do combustível na mistura ar-combustível. Altas temperaturas e pressões do ar admitidos são fatores que aumentam os picos de temperatura durante a queima, aumentando assim a probabilidade de componentes serem super-aquecidos e gerar a ignição anormal da mistura ar-combustível. A baixa octanagem do combustível também pode aumentar a ocorrência de detonação. O retardo do ponto de ignição é uma forma de reduzir a probabilidade de detonação devido à redução da pressão resultante da queima (MAGNUSSON, 2007).

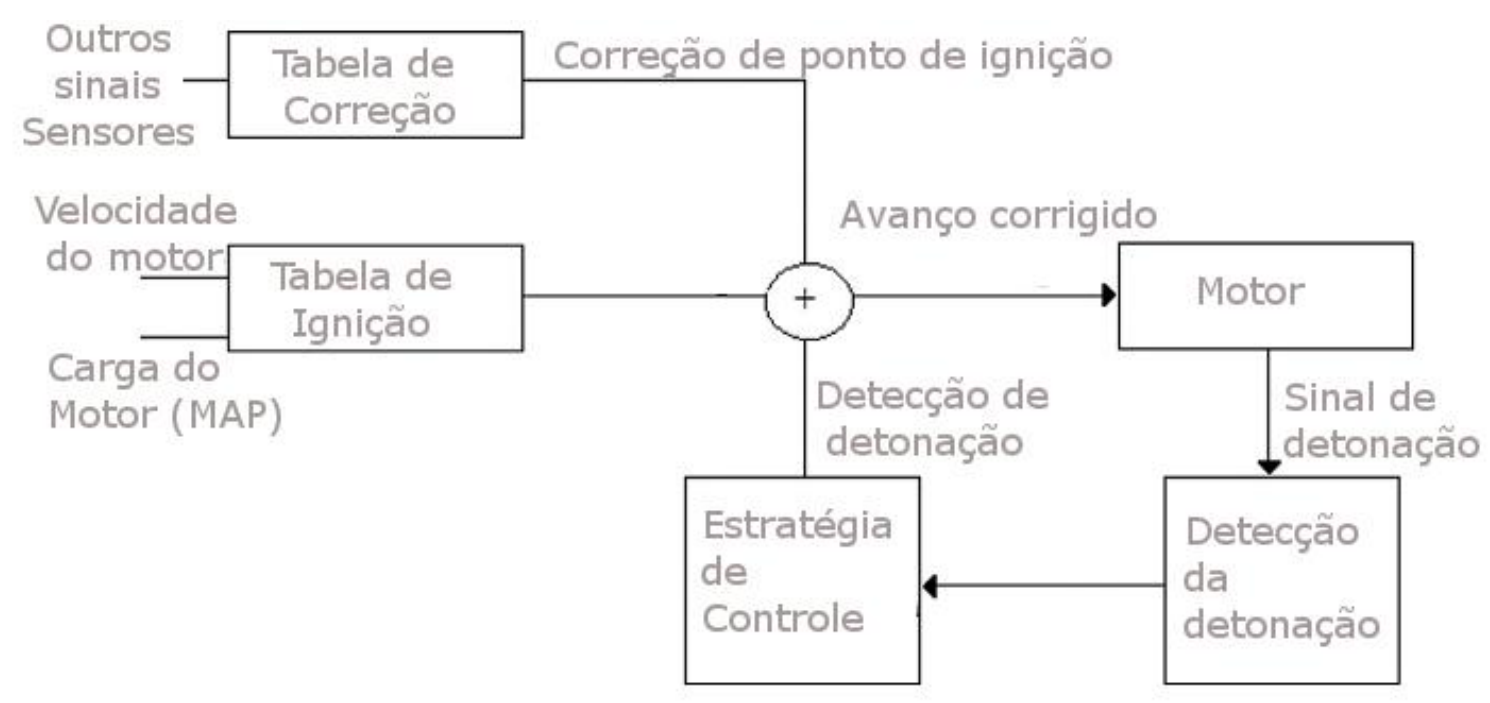

Figura 27 - Estratégia de controle de detonação baseada no ponto de ignição.

Fonte: Adaptado de Ashok, Ashok e Ramesh Kumar (2016).

Na figura 27, é apresentada uma estratégia básica de controle feedforward e feedback para controle do avanço de ignição do motor, em que os valores de avanço de ponto de ignição são corrigidos pela malha de controle de detonação. As seguintes ações também podem ser tomadas para a redução da ocorrência de detonação (NIELSEN; KIENCKE, 2005; ASHOK; ASHOK; RAMESH KUMAR, 2016):

- Redução da temperatura do ar aspirado utilizando-se intercoolers ou enriquecendo a mistura ar combustível $(\lambda<1)$.

- Localizar a vela de ignição no centro do cilindro para diminuir o tempo de propagação da frente de chama por toda a câmara de combustão. 
- Aumentar a turbulência dos gases para aumentar a velocidade de propagação da frente de chama.

- Limitar a pressão de sistemas superalimentados.

Guzella e Onder (2010) observam que os motores com ignição por centelha geralmente estão limitados pela detonação nos regimes de alta carga e baixas velocidades. Nesses regimes há tempo, temperaturas e pressões suficientes para que a queima anormal ocorra. A detonação é um fator limitante para o aumento de eficiência dos motores, pois faz com que os sistemas tenham que operar com limitados valores de taxa de compressão e avanço de ignição. 


\section{Protótipo da Unidade de Controle}

A unidade de controle proposta nesse trabalho tem por função ser uma base para desenvolvimento de sistemas em pesquisas sobre controle de motores de combustão interna. Portanto, a unidade de controle deve ser flexível e bem equipada para que melhorias possam ser feitas e o sistema possa evoluir com o tempo. Considerando a análise realizada por Pujatti (2007) sobre sistemas de gerenciamento eletrônicos programáveis e nos sistemas da Bosch Motorsport (2016) e Megasquirt ${ }^{\circledR}$ (BOWLING AND GRIPPO, 2014), foram estabelecidas as seguintes características básicas desejadas para o desenvolvimento da UCM:

1- Liberdade de variação da relação ar-combustível em tempo real via PC (Personal Computer).

2 - Ajuste de ponto de ignição em tempo real via PC.

3 - Injeção multiponto sequencial.

4 - Livre escolha do ângulo de injeção de cada bico injetor com precisão mínima de 1 grau em tempo real.

5 - Livre escolha do ponto de ignição para cada cilindro com precisão mínima de 1 grau em tempo real.

6 - Facilidade de alterações de código do controlador para expansão de funcionalidades e melhoria das existentes.

7 - Entradas analógicas em quantidade suficiente para futura expansão do sistema.

8 - Mínimo de 24 saídas digitais para comando de bicos, bobinas, válvulas e saídas auxiliares.

9 - Velocidade de aquisição A/D (analógico-digital) no mínimo 10 vezes maior que a velocidade de variação do estado mais rápido do sistema, considerando somente os estados que podem ser lidos e frequência do eixo do motor de 15000 rotações por minuto.

10 - Capacidade de processamento para controle de próximo ciclo na frequência máxima de rotação do eixo do motor como sendo de 15000 rotações por minuto.

11 - Comando direto das bobinas de ignição e bicos injetores.

12 - Duas entradas para sensores de relutância variável, utilizados para roda fônica e sensor de fase, mais duas entradas para futura detecção de sentido de rotação do motor e velocidade da carroceria do veículo. 
13 - Interface de configuração executada em microcomputador se comunicando através de porta USB (Universal Serial Bus) com o controlador.

14 - Memória não volátil para armazenamento de tabelas estáticas (aproximadamente 2000 bits por tabela) de controle e todos os outros parâmetros de funcionamento do sistema que podem ser programados pelo próprio controlador durante a operação.

15 - Saída para estroboscópio, permitindo ajustes de defasagens causadas pelo posicionamento não preciso do sensor de relutância variável da roda fônica.

16 - Sensor de pressão dentro do coletor de admissão embutido no controlador e com limite de pressão absoluta de $200 \mathrm{kPa}$.

17 - Utilização de hardware de baixo custo e software livre para que haja facilidade na fabricação do sistema e seu uso em pesquisas.

\subsection{Hardware}

Para cumprir com todos os requisitos indicados na introdução do capítulo 6 , foi escolhido o microcontrolador ATSAM3X8E, utilizado na placa de prototipagem Arduino Due. Inicialmente, os critérios de escolha do componente foram principalmente:

- Disponibilidade no mercado nacional.

- Popularidade do microcontrolador, o que implica em maior suporte por parte da comunidade de projetistas, engenheiros e programadores que utilizam tais componentes.

- Afinidade do autor com o dispositivo devido a experiências anteriores.

Com essa definição inicial, realizou-se o estudo das características do microcontrolador comparadas às exigências observadas na introdução do capítulo 4, como pode ser visto a seguir:

- A taxa máxima de amostragem do microcontrolador é de $1 \mathrm{MHz}$ e pode ser dividida pelas doze entradas analógicas disponíveis ( $83333 \mathrm{~Hz}$ por porta). Na velocidade de 15000 RPM (Rotações por Minuto), são realizadas 333 amostras por ciclo do motor $(15000 / 60=250$ $\mathrm{Hz}$ ), o que cumpre parcialmente com a exigência número 9. Considerando a pressão dentro do cilindro do motor como sendo o estado mais rápido a ser lido, seria possível a leitura com baixa taxa de amostragem, que seria ainda mais limitada pela redução da taxa de amostragem devido ao período de execução das rotinas padrão do microcontrolador. Portanto, a taxa de 
amostragem inicial do microcontrolador não é o limitante sobre a leitura de sinais, mas não há garantia de que será possível obter essa taxa de amostragem com futuros códigos a serem executados pelo microcontrolador.

- O microcontrolador não apresenta um bom suporte a memória não volátil, os dadoos manipulados pelo programa só podem ser gravados na própria memória de programa, o que não é o ideal para o projeto já que a quantidade de gravações permitidas por essa memória (FLASH) é muito inferior ao de uma EEPROM (Electrically-Erasable Programmable ReadOnly Memory). Portanto uma memória EEPROM externa é requerida. A memória utilizada para suprir essa necessidade é a 24LC256.

Essa memória foi escolhida pelos seguintes motivos:

- Baixo custo.

- Fácil integração por se comunicar por padrão I2C (Inter-Integrated Circuit).

- Capacidade de armazenamento de 256kbits, valor que permite armazenamento de mais de 100 tabelas estáticas (injeção de combustível e ou ponto de ignição) de configuração do controlador.

- Analisando o item 10, percebe-se que é difícil determinar a capacidade necessária de processamento do controlador, já que o peso de processamento está em função do algoritmo de controle, o qual ainda não está disponível.

Por fim, é considerada a interface de programação e facilidade de envio do firmware para a placa de prototipagem. A placa de desenvolvimento Arduíno tem disponível uma IDE (Integrated Development Environment) de código livre que tem grande suporte pela comunidade de programadores e o microcontrolador ATSAM3X8E permite a gravação direta via uma USB nativa.

Portanto, apesar de não ter sido realizado um estudo aprofundado das opções existentes no mercado, como exemplo, microcontroladores automotivos, optou-se pelo prosseguimento do projeto com a utilização do microcontrolador ATSAM3X8E devido aos pontos já comentados. 


\subsubsection{TPU (Time Processing Unit)}

Inicialmente considerou-se o desenvolvimento de um sistema completo sendo executado pelo microcontrolador escolhido. No entanto, a complexidade de código para atender as exigências 3, 4, 5 e 6 seria grande e consumiria muito tempo para desenvolvimento.

Em Guzzella e Onder (2010), é feita uma breve discussão sobre o hardware de sistemas de controle. Os autores comentam a respeito de sistemas operacionais de tempo real (RTOS) proprietários sendo executados pelas CPU's (Central Processing Unit) das UCM's no mercado. Além disso, ainda é utilizado mais um componente de hardware chamado TPU (Time processing unit), que é encarregado de sincronizar os comandos do sistema de controle com a posição do eixo do motor.

Devido aos problemas inerentes a aplicar um RTOS ao microcontrolador utilizado e à dificuldade de codificar um sistema flexível como esperado pela exigência 6 , foi tomada a decisão de desenvolver um sistema trabalhando com dois processadores de forma assíncrona, como visto em Guzzella e Onder (2010). O uso de um FPGA se mostrou interessante para a função de TPU devido à facilidade de criação de processos paralelos, o que simplifica a inclusão de novos componentes ao sistema (figura 28).

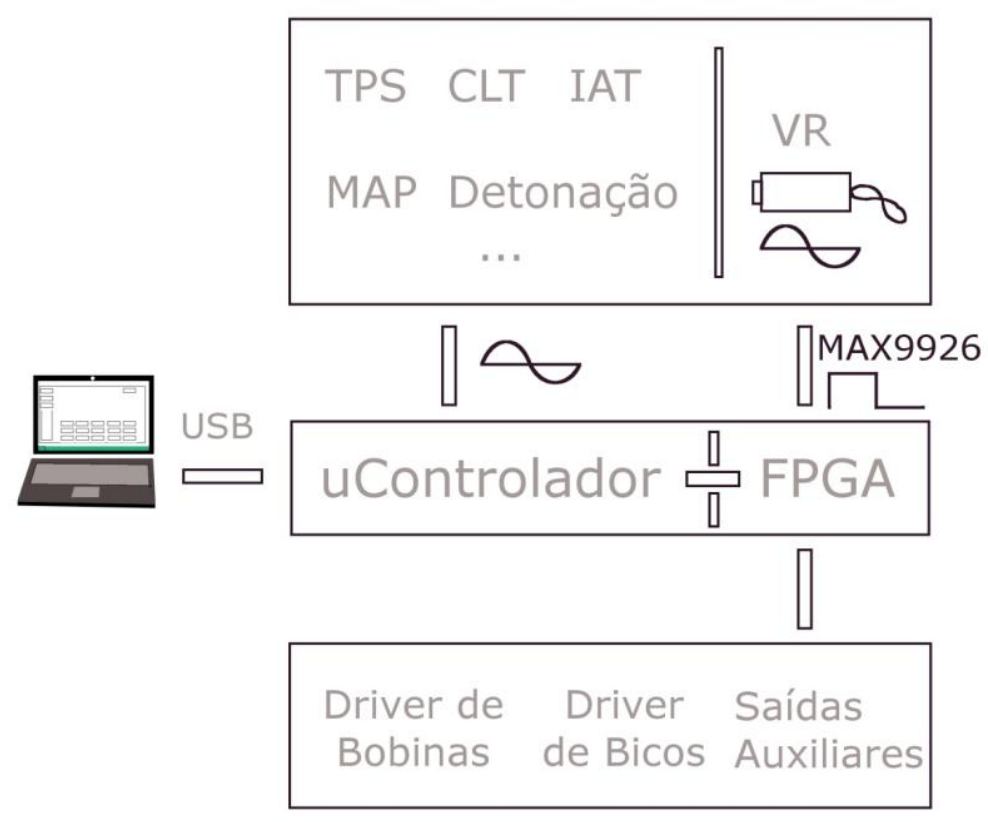

Figura 28 - Estrutura básica do sistema. 
A linguagem de descrição de circuitos utilizada é o VHDL (VHSIC Hardware Description Language). O FPGA escolhido (SPARTAN6 - XC6SLX25) é utilizado na placa de prototipagem Xula 2 da empresa XESS Corporation. A tabela 1 lista as características principais do FPGA.

Tabela 1 - Características principais do FPGA (XC6SLX25).

Células lógicas 24051

Multiplicadores

38

DCMs

4

PLLs

2

Entradas/Saídas

$33 / 33$

Fonte: (http://www.xess.com/shop/product/xula2-lx25/).

Dessa forma, foi definido que o módulo constituído pelo microcontrolador (ATSAM3X8E) seria responsável pelas seguintes funções:

- Leitura dos sensores.

- Execução do algoritmo de controle.

- Envio para a TPU dos valores utilizados para comando dos atuadores.

- Comunicação com o programa supervisório para gravação de parâmetros na memória.

O FPGA ficaria responsável por:

- Estimar a posição atual do eixo do motor.

- Comandar os atuadores em sincronismo com o sistema mecânico, de acordo com o que é indicado pelo microcontrolador. 


\subsubsection{Tratamento do Sinal do Sensor de Relutância Variável}

As características do sinal gerado pelo sensor de relutância variável (VR - Variable Reluctance) fazem com que seja necessário um tratamento prévio para que ele possa ser conectado ao FPGA (exigência 12). Para essa função, foi escolhido o circuito integrado MAX9926 (figura 29).

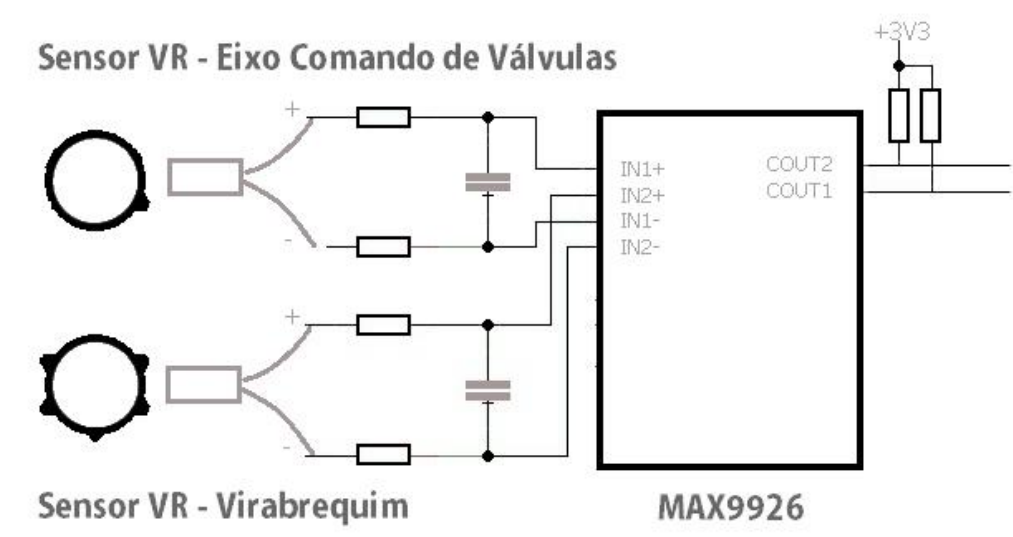

Figura 29 - Interface dos sensores VR

A escolha do circuito integrado se deve à facilidade de integração e às seguintes características:

- Ajuste automático do limiar de tensão: Utilizado para comparação com o sinal vindo do sensor para a geração da onda quadrada (figura 11).

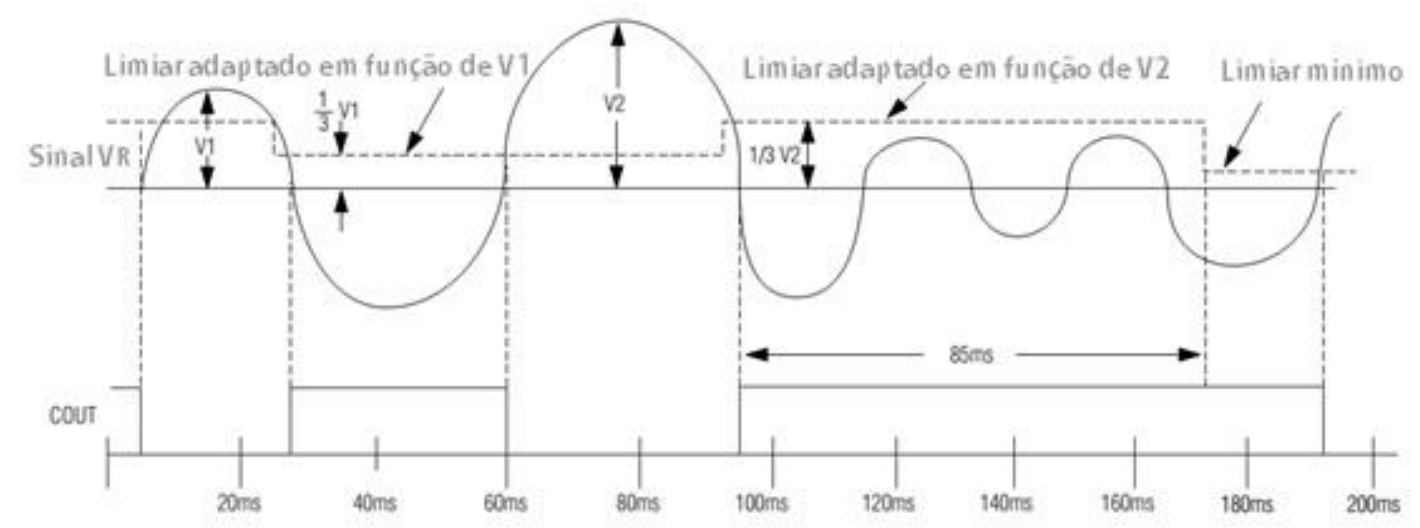

Figura 30 - Limiar Adaptativo

Fonte: (MAXIM INTEGRATED PRODUCTS, 2012) 
- Saída de direção de rotação: Essa característica permite satisfazer por completo a exigência do item 12. Com o uso de dois sensores VR ligados ao circuito integrado, é possível detectar o sentido de rotação do motor.

\subsubsection{Saídas de Potência}

O comando dos atuadores exige componentes de potência que suportem as correntes drenadas pelos atuadores e os picos de tensões gerados. A seguir são apresentados os circuitos eletrônicos utilizados para o comando dos atuadores e o funcionamento desses.

\subsubsection{Bicos Injetores}

Para comando dos bicos injetores, foram utilizados transistores MOSFET de uso geral com corrente máxima de condução de 40 Amperes. Para proteção dos transistores e das bobinas dos bicos, são utilizados diodos zener em paralelo com os transistores, para permitir a desenergização das bobinas (figura 31) (TEXAS INSTRUMENTS, 2015).

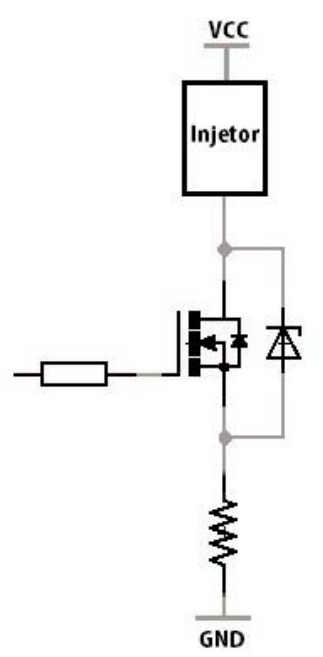

Figura 31 - Circuito de potência para comando de bicos injetores 
Para o comando de solenoides, é necessário um circuito de controle de corrente, devido à corrente necessária para abrir o solenoide ser algumas vezes maior que a corrente necessária para mantê-lo aberto (TEXAS INSTRUMENTS, 2015). Na figura 32, são apresentadas as formas de ondas presentes no circuito em operação, sendo:

- Vp: Tensão de pico sobre o resistor shunt.

- Vr: Tensão de regime sobre o resistor shunt.

- Vz: Tensão reversa do diodo zener.

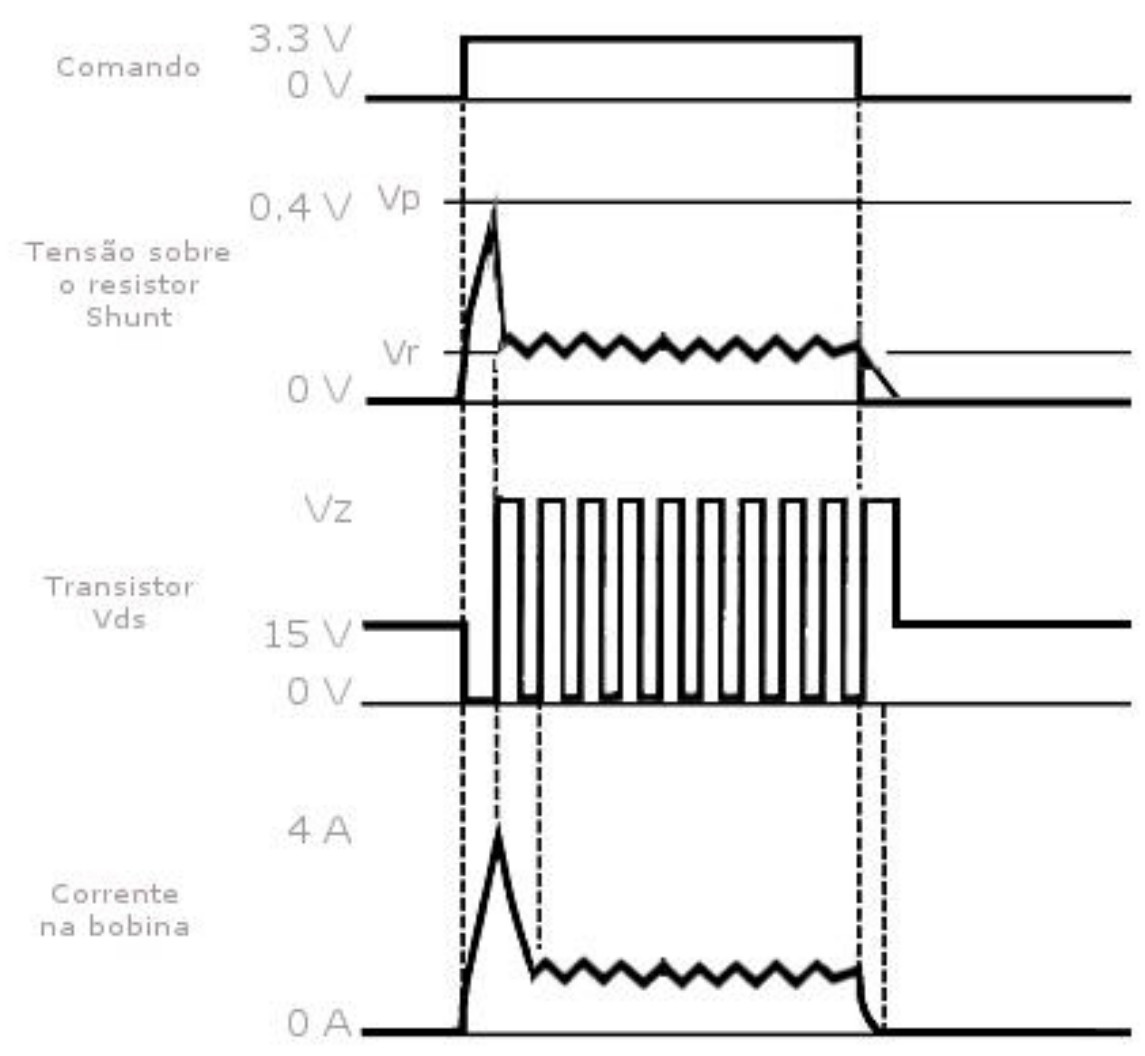

Figura 32 - Formas de ondas no circuito.

Inicialmente, o circuito alimenta o bico injetor durante o período suficiente para que a corrente no solenoide atinja o valor necessário para que o bico abra, o que é indicado pela tensão 'Vp' sobre o resistor shunt. Com o bico aberto, a corrente pode ser reduzida para a corrente de regime, indicada pela tensão ' $V r$ ' sobre o resistor shunt. O controle de corrente, nesse caso, é realizado com modulação de largura de pulso (PWM). 
A sobretensão entre coletor e emissor do transistor sempre que ocorre uma comutação é devida à inversão de polaridade e aumento da tensão observado na bobina do solenoide quando o fluxo de corrente é interrompido. O aumento de tensão persiste até o nível de tensão se igualar ao valor de tensão reversa do diodo zener. Nesse momento, a corrente flui pelo diodo, gerando a curva de corrente descendente que circula pelo injetor. Esse processo de energização e desenergização persiste durante o período de regime com o sinal de corrente semelhante a uma onda triangular.

\subsubsection{Bobina de ignição}

Para comando de bobinas de ignição, não é recomendado o uso de transistores de uso geral, pois os picos de tensão observados no primário do transformador podem prejudicá-los (figura 34.c). Portanto, para essa função, foi escolhido um driver de uso especifico (figura 33), com limitação de corrente de 12 Amperes, proteção contra sobreaquecimento e entrada de comando compatível com níveis de lógica CMOS (Complementary Metal Oxide Semiconductor) (Bosch Microelectronics, 2016).

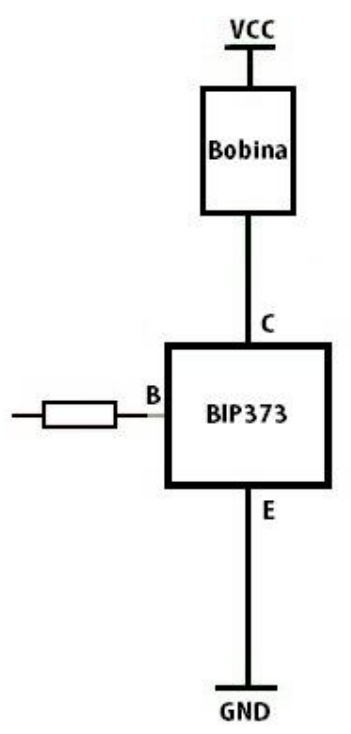

Figura 33 - Saída de potência para comando de bobinas de ignição

As bobinas de ignição trabalham com ciclos de energização e desenergização para geração de alta tensão. Cada ciclo de geração de centelha compreende quatro passos (figura 34): 
- Alimentação do primário do transformador: $\mathrm{O}$ driver de potência é comandado para iniciar o processo de energização da bobina (figura 34.a).

- Energização: Período durante o qual a bobina estoca energia em seu campo magnético, também chamado de dwell time (figura 34.b).

- Corte da alimentação: Momento em que o driver de potência corta a corrente pelo primário do transformador (figura 34.c).

- Desenergização: A energia estocada no campo magnético é convertida em corrente no secundário do transformador, o que só é possível com o rompimento da barreira de potencial entre os eletrodos da vela (figura 34.d).

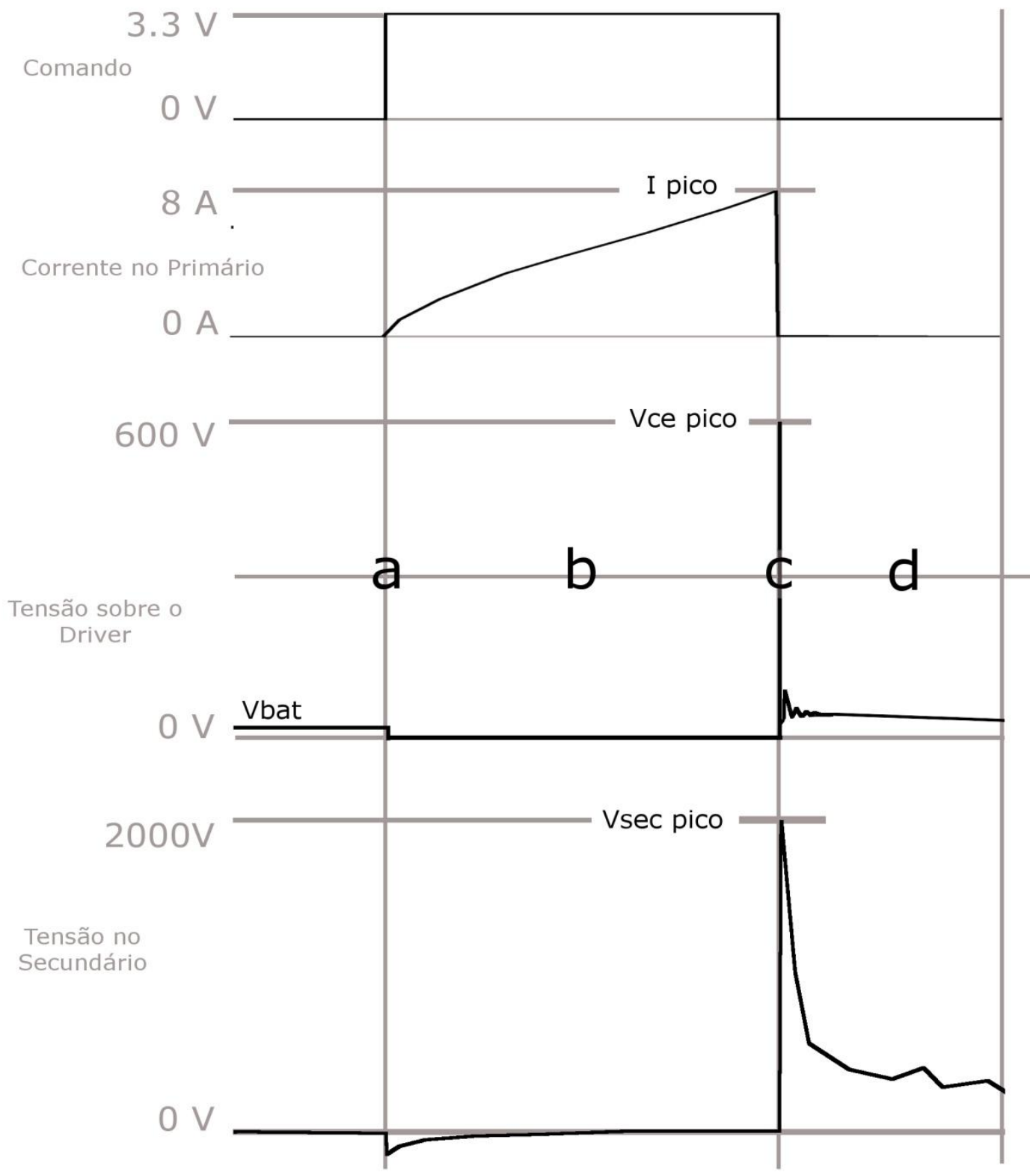

Figura 34 - Ciclo de geração de centelha. 


\subsubsection{Primeira placa protótipo desenvolvida}

$\mathrm{Na}$ figura 35, é apresentado o protótipo inicial da UCM. Nessa placa, foram integradas as duas placas protótipos, Xula 2 e Arduino Due. Na montagem, somente o circuito integrado MAX9926 é um componente de montagem de superfície.

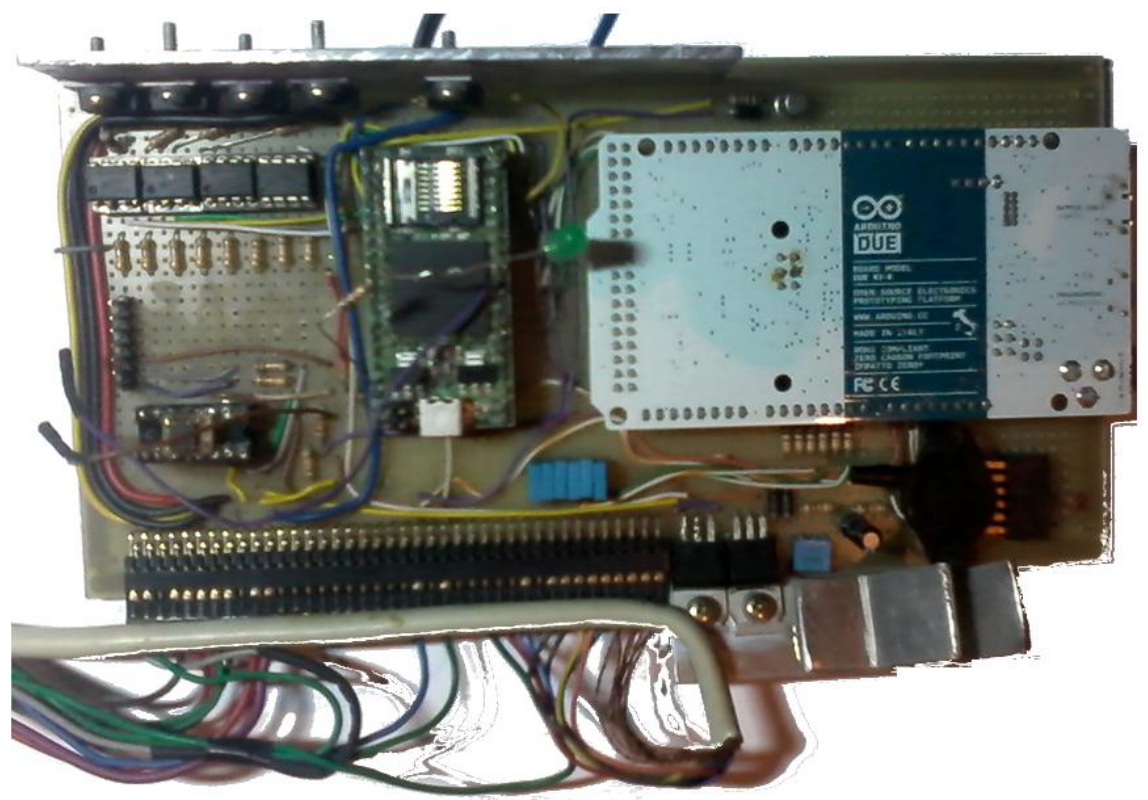

Figura 35 - Protótipo do Controlador

Os seguintes circuitos auxiliares foram montados junto com as placas de protótipos:

- Circuito de potência para alimentação de bobinas e bicos: Foram construídos com drivers específicos (BIP373), no caso das bobinas de ignição, e com transistores MOSFET (Metal Oxide Semiconductor Field Effect Transistor), para os drivers de bicos injetores.

- Circuito condicionador para sensores de relutância variável (posição do eixo): Utilizado o circuito integrado MAX9926.

- Fonte de alimentação: Utilizaram-se dois reguladores de tensão LM7805 em paralelo, para redução da tensão da ordem de $14 \mathrm{~V}$ para $5 \mathrm{~V}$. O consumo de corrente medido está na ordem de $600 \mathrm{~mA}$. 
- Drivers de transistores MOSFET: Para correto comando dos transistores, foram incluídos drivers específicos com a função de converter a tensão de 3,3V da saída do FPGA para a tensão ideal de comando da porta dos transistores.

Os ensaios iniciais de software e hardware são descritos no capítulo 7. Depois de realizados esses ensaios iniciais, o trabalho foi voltado para o desenvolvimento de uma segunda placa protótipo, que agora utiliza somente os componentes necessários para o funcionamento do sistema.

\subsubsection{Segunda placa protótipo}

O desenvolvimento da segunda placa protótipo se deu com os seguintes passos:

- Inicialmente, foi definido o circuito mínimo necessário para que o microcontrolador operasse com suporte a comunicação USB. Para isso, é obrigatório o uso de um cristal para geração da base de tempo com precisão exigida pelo circuito de comunicação USB.

- O circuito para configuração do FPGA foi escolhido de acordo com o que é explanado no item 4.1.5.1 (Configuração do FPGA) e é realizada pelo microcontrolador no início da operação do sistema.

- A fonte escolhida para ser utilizada no circuito é a mesma encontrada na placa de prototipagem Arduino Due. Devido a sua corrente máxima estar em torno de $1 \mathrm{~A}$, há uma boa margem sobre os $600 \mathrm{~mA}$ medidos como consumo máximo da primeira placa protótipo.

- Foi realizada a escolha de um FPGA diferente do encontrado na placa Xula 2, devido ao tipo de encapsulamento do circuito integrado tornar complicada a montagem manual na placa. O FPGA (XC6SLX25) com encapsulamento BGA-FT256 (Ball Grid Array) foi substituído pelo FPGA XC6SLX9, que é um chip mais barato, com menos portas e com encapsulamento TQFP144 (figura 36), que, de acordo com os relatórios do programa ISE Design, consegue cumprir com folga as exigências do sistema. A tabela 2 contém os dados referentes ao uso dos principais recursos dos dois FPGA's para o código final. 


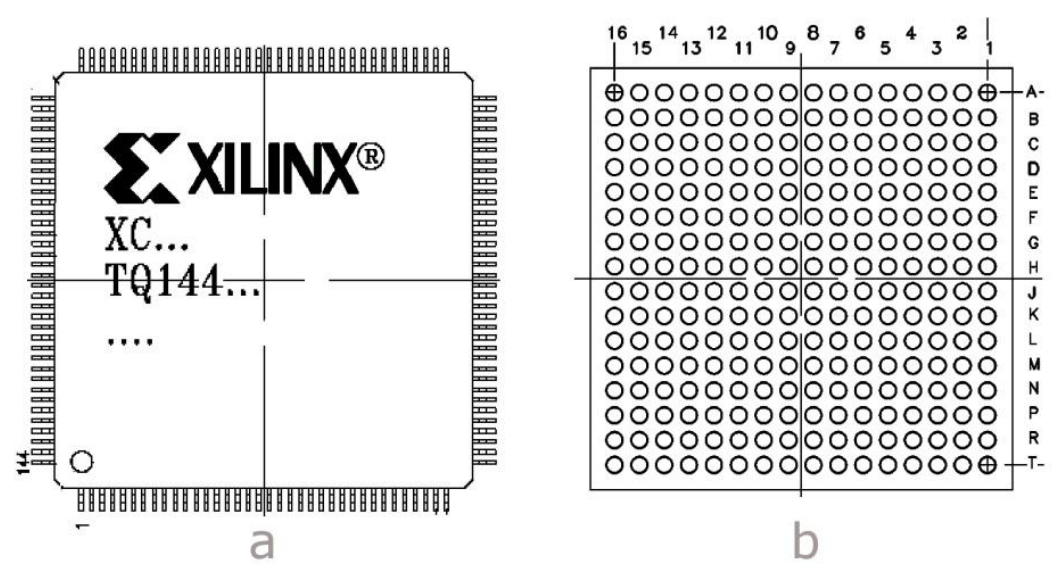

Figura 36 - Encapsulamentos TQFP144 (a) e FT256 (b). Fonte: (XILINX, 2014)

Tabela 2 - Utilização dos recursos dos FPGA's

\begin{tabular}{ccc}
\hline Recurso & XC6SLX25 & XC6SLX9 \\
\hline Registros Slice & 1021 de $30064-3 \%$ & 1113 de $11440-9 \%$ \\
LUTs & 2777 de $15032-18 \%$ & 2923 de $5720-51 \%$ \\
IOBs & 18 de $186-9 \%$ & 18 de $102-17 \%$ \\
DCMs & 1 de $4-25 \%$ & 1 de $4-25 \%$ \\
DSP48A & 2 de $38-5 \%$ & 3 de $16-18 \%$ \\
\hline
\end{tabular}

A placa confeccionada com os componentes soldados pode ser observada na figura 37. Essa placa passou por processos de ensaios descritos no capítulo 7.

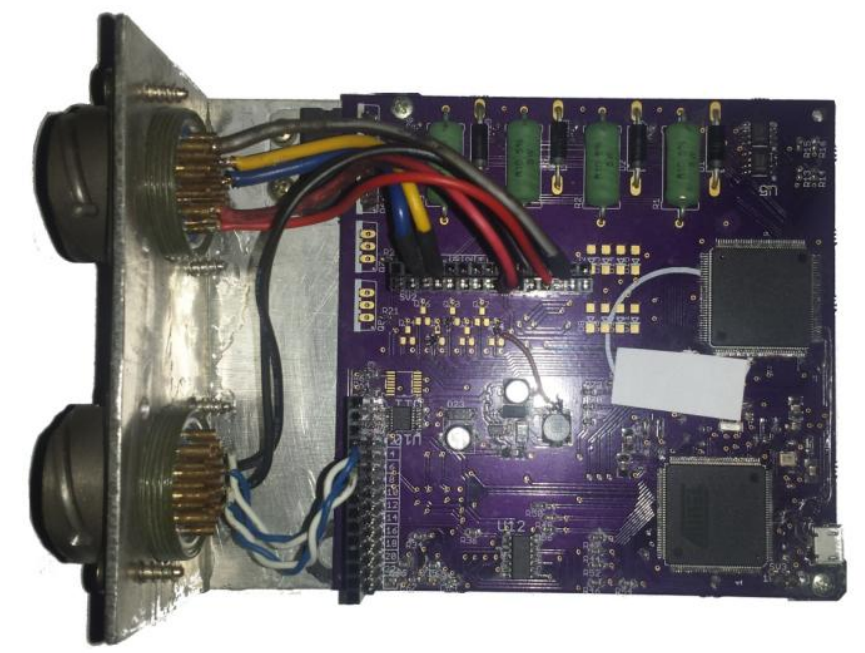

Figura 37 - Segunda placa protótipo. 


\subsubsection{Configuração do FPGA}

A configuração do FPGA é realizada no modo serial-escravo. Nesse modo o FPGA fica como módulo escravo e recebe todos os comandos de configuração do microcontrolador conectado a ele (figura 38).

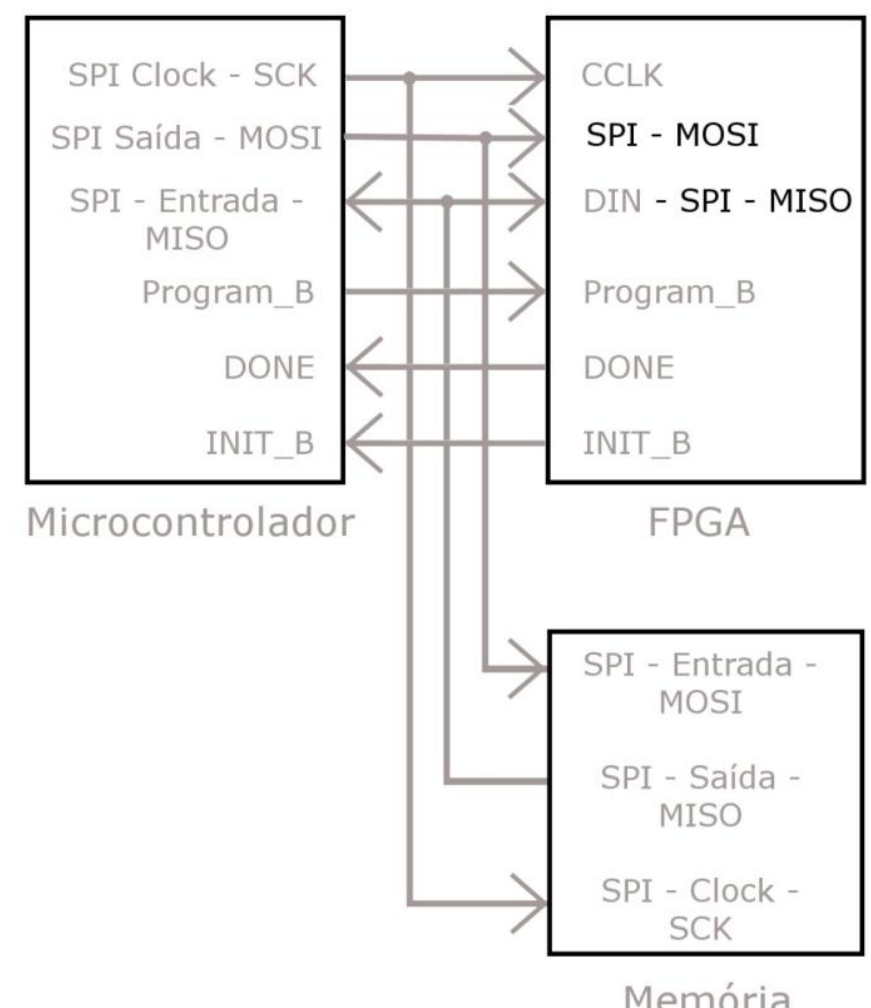

Figura 38 - Circuito de configuração e comunicação SPI do FPGA.

O código carregado no microcontrolador inicia todas suas funções e configura o FPGA antes de começar a carregar seu código padrão. O microcontrolador precisa desabilitar o FPGA sempre precisa se comunicar com a memória flash, isso se deve à linha de comunicação MOSI (Master Out Slave In) estar sempre enviando comandos ao FPGA. Caso o sinal enviado para a memória seja, de alguma maneira, entendido pelo FPGA, um erro de comando será gerado e o FPGA pode comandar algum atuador incorretamente.

O processo de configuração e comunicação SPI ocorre da seguinte maneira (figura 39): 
- O microcontrolador executa as rotinas de inicialização e fica pronto para iniciar a configuração do FPGA.

- Nível lógico do pino PROGRAM_B é levado para nível lógico '0’ pelo microcontrolador.

- O microcontrolador espera que o nível lógico do pino INIT_B seja levado para '0’ pelo FPGA.

- Nível lógico do pino PROGRAM_B é levado para '1'.

- O microcontrolador espera que o nível lógico do pino INIT_B vá para '1'.

- O microcontrolador inicia a leitura completa da memória flash enviando um comando de leitura do primeiro espaço de memória e continua enviando pulsos de clock para a memória flash até que o nível lógico do pino DONE vá para '1', o que indica a configuração completa do FPGA.

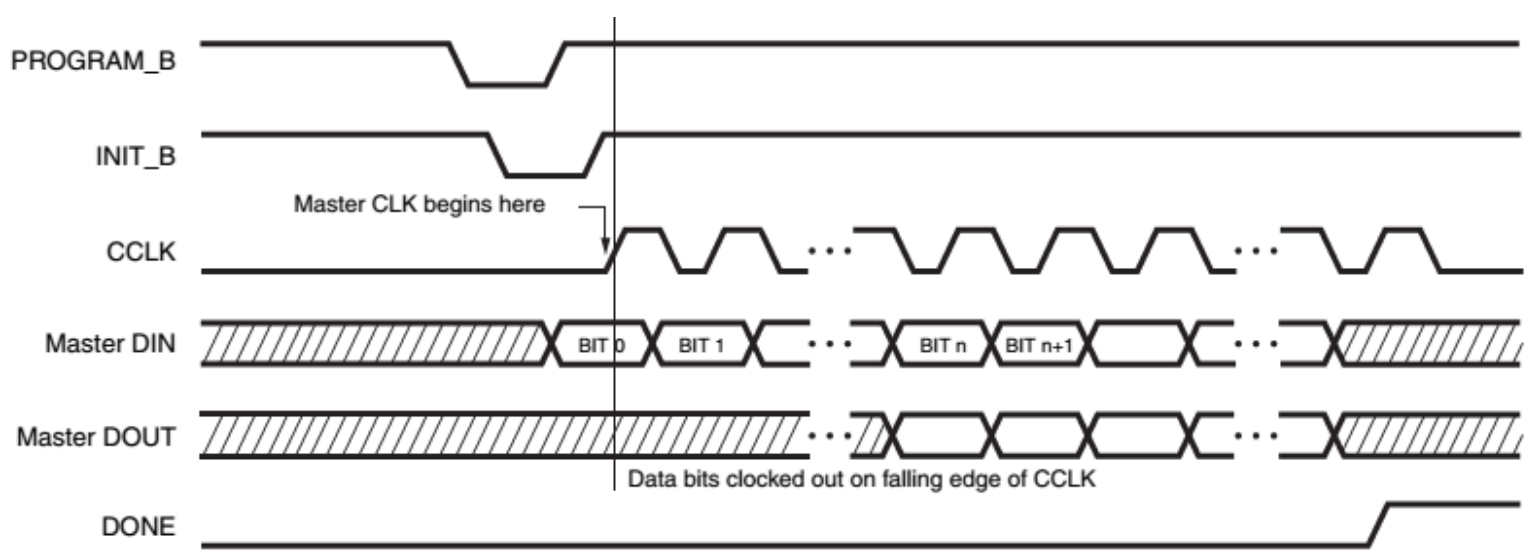

Figura 39 - Rotina de configuração do FPGA. Fonte: (XILINX, 2015)

Esse tipo de configuração é possível devido à memória ter uma função de leitura contínua que necessita somente de um comando de leitura e pulsos de clock contínuos para que todos os dados da memória sejam descarregados pela porta serial, enviando assim todo o código para o pino DIN, que é o pino dedicado à configuração do FPGA. Depois de carregado, o FPGA entra em operação e os pinos DIN e CCLK ficam livres para serem utilizados como portas de uso geral. Nesse momento, é iniciado o código de rotina no microcontrolador e o FPGA começa a receber os dados de comando dos atuadores.

Nesse momento, a memória flash também é desabilitada, para que ela não receba comandos por engano pela linha de comunicação SPI. Devido à entrada DIN deixar de ser uma entrada e se tornar uma saída, observou-se que durante a transição de funções poderia 
haver a chance de duas saídas se conectarem ao mesmo tempo. Portanto, por segurança essa saída do FPGA (MISO) foi configurada para operar com dreno aberto, ficando em nível lógico ' 0 ' para saída de nível lógico ' 0 ' e em alta impedância para saída de nível lógico ' 1 '.

Os dados a serem gravados na memória flash são enviados com o auxílio de uma interface criada em LabView (figura 40). O programa da interface é responsável por se comunicar via conexão serial com o microcontrolador e enviar todo o arquivo de configuração do FPGA. Esses dados são posteriormente utilizados pelo próprio microcontrolador para configurar o FPGA.

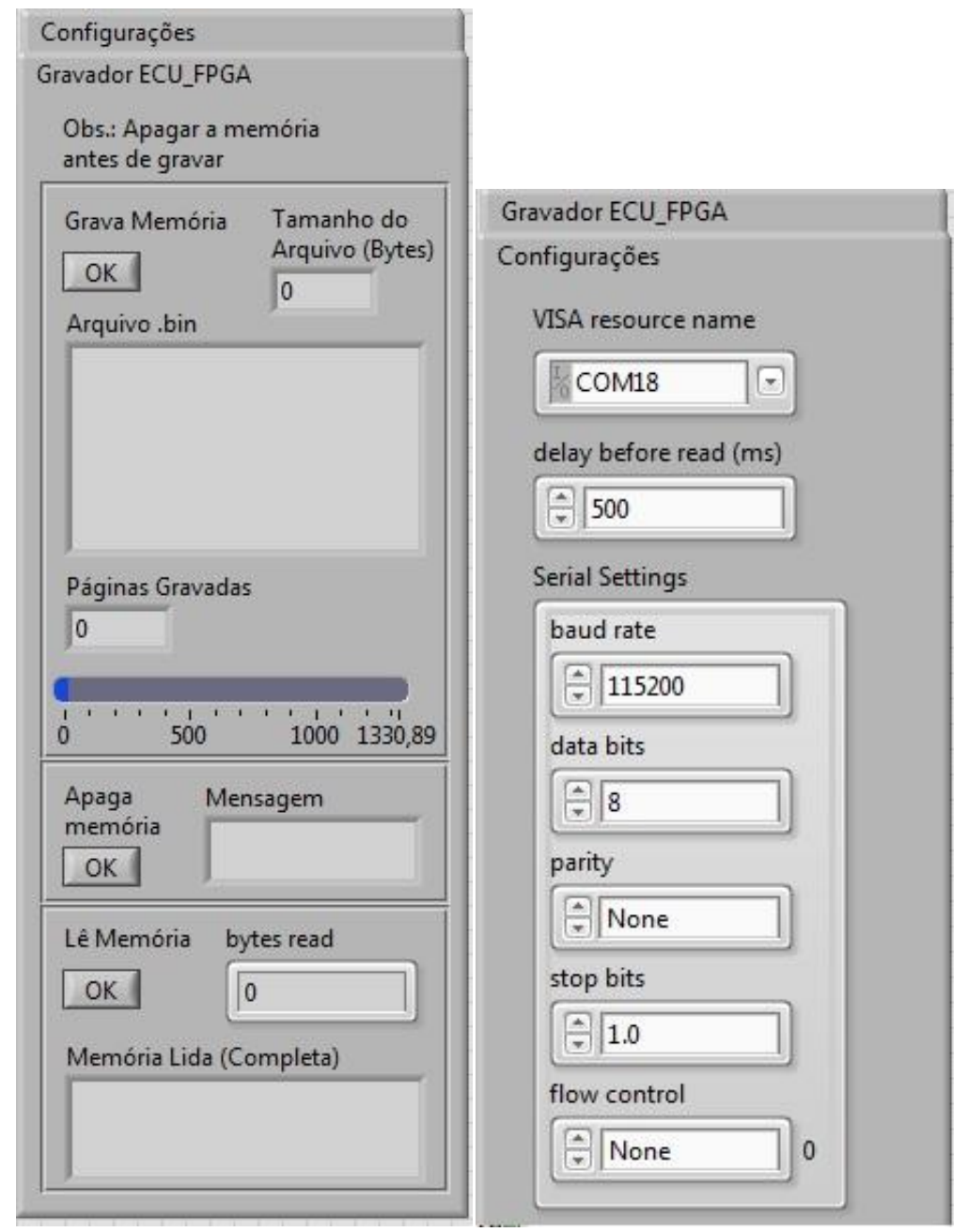

Figura 40 - Interface para gravação do arquivo de configuração do FPGA.

A interface possibilita ao operador as seguintes ações:

- Gravação de todo o arquivo de configuração: O botão com o título "Grava memória" abre uma caixa de dialogo que pede para o operador indicar a localização do arquivo '.bin' que será carregado na memória Flash. 
- Apagamento da memória Flash: Um comando é enviado ao microcontrolador para que a memória flash seja completamente apagada.

- Leitura da memória Flash: Comandos consecutivos são enviados para realizar a leitura completa da memória Flash.

A interface também apresenta uma aba de configurações da comunicação serial, que deve ser configurada de acordo com as configurações da porta serial virtual criada pelo microcontrolador ao se conectar na porta USB.

Inicialmente, o código em LabView carrega as configurações da comunicação serial e abre a porta para inicio da comunicação entre o microcomputador e o microcontrolador (figura 41). O código separa todos os dados vindos do painel de configurações e os envia para o bloco de configuração serial chamado VISA SERIAL, que se encarrega de abrir a porta com as configurações vindas de Serial Settings.

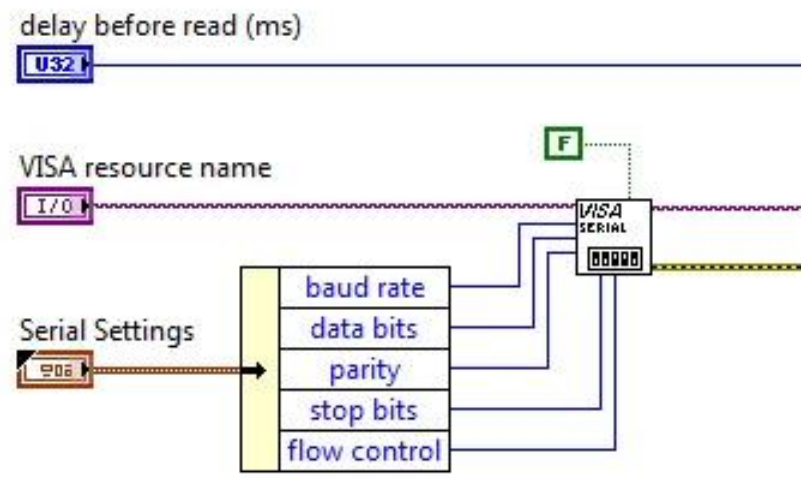

Figura 41 - Abertura e configuração da porta serial.

Com a porta de comunicação aberta, o código passa para o passo seguinte e abre uma caixa de diálogo para que o arquivo de configuração do FPGA (.bin) seja carregado (figura 42). O código também identifica e carrega indicadores com a quantidade de bytes do arquivo (Tamanho do Arquivo) e com os dados em forma de texto (Arquivo .bin). 


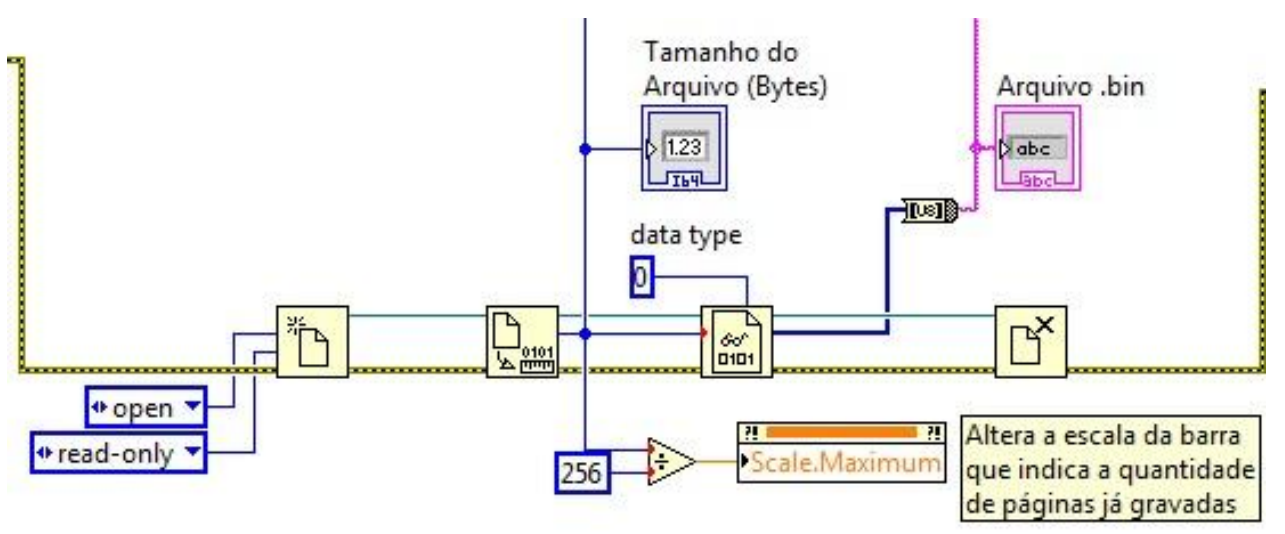

Figura 42 - Código para abrir arquivo de configuração.

Tendo sido identificado o tamanho do arquivo, o código calcula em quantas páginas de 256 bytes esses dados podem ser separados. Isso se deve aos espaços internos da memória flash serem organizados por páginas com tamanho de 256 bytes cada.

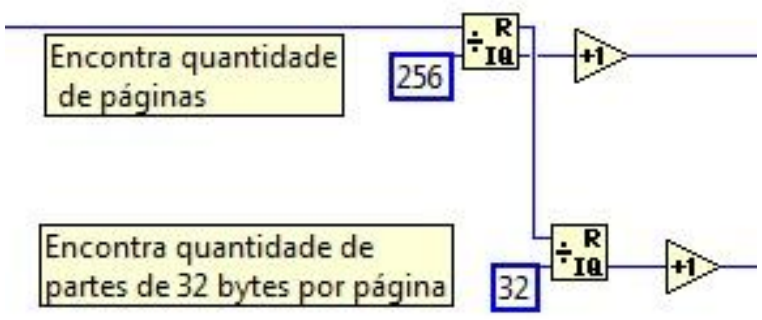

Figura 43 - Identificação da quantidade de páginas e de partes do arquivo.

Além da separação em páginas, o código também separa essas páginas em partes de 32 bytes (figura 43), que é a quantidade de dados enviados por pacote durante a comunicação.

Durante a maior parte do processo, o código encontra o valor de oito partes por página $(8 \times 32$ =256). No entanto, a última página do arquivo pode não apresentar oito partes, então o programa encontra a quantidade de partes e passa adiante para o controle de envio de dados para o microcontrolador. 


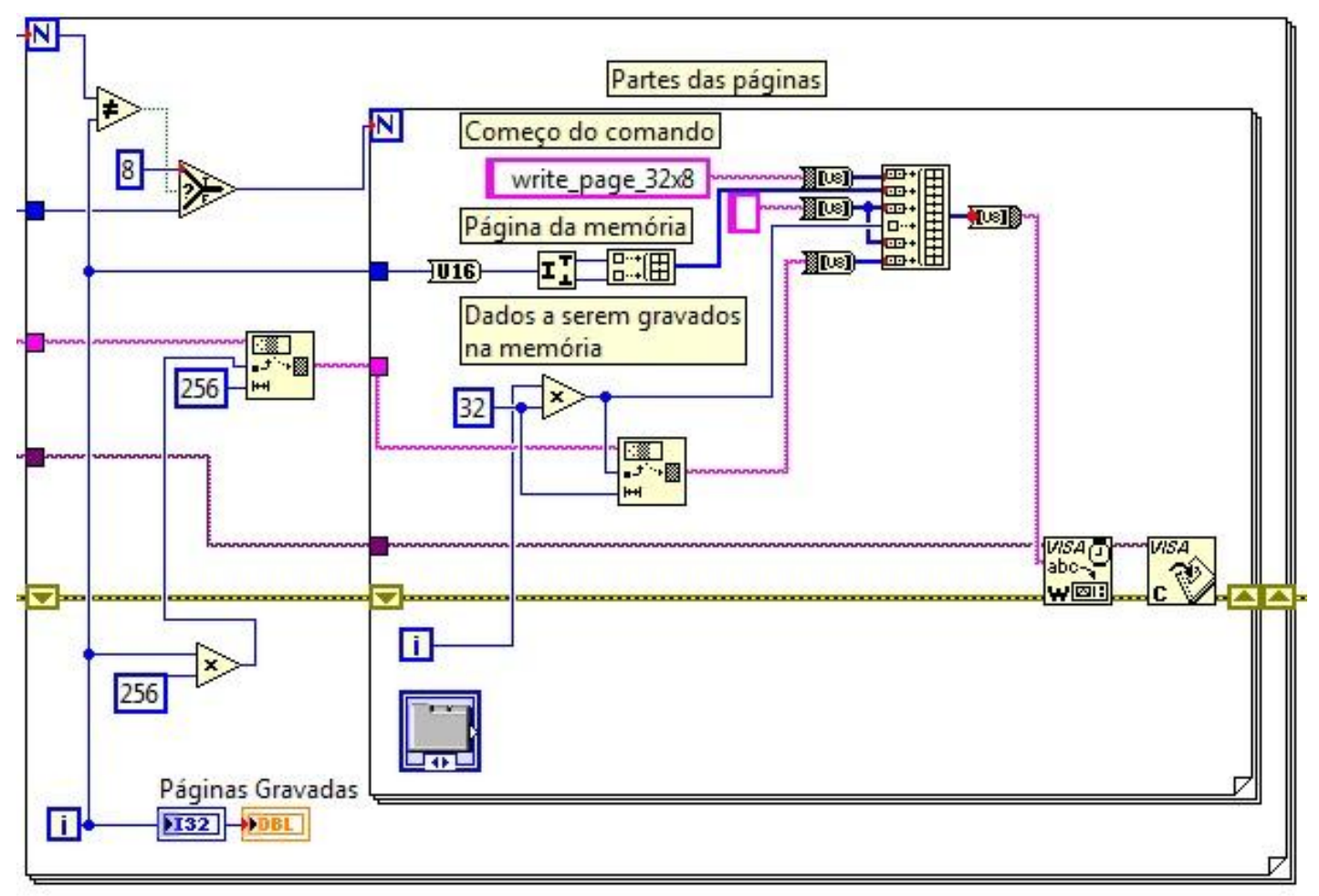

Figura 44 - Loops For de envio de dados.

Por fim, o código entra em dois loops for utilizados para montar o vetor de comando com os dados a serem enviados (figura 44). O comando é construído por uma variável do tipo string com a seguinte estrutura:

GravaXX Y DDD(32)

Onde:

- Grava: Comando inicial para o sistema entender que é um comando de gravação de memória.

- XX: Dado de 16 bits formado por dois bytes que indica qual a página da memória a ser gravada.

- Y: Byte utilizado para indicar em qual parte da página os dados serão gravados.

- DDD(32): Dados a serem gravados na memória flash, têm o tamanho de 32 bytes.

Todo o ciclo de gravação da memória flash é executado com o FPGA e com as rotinas padrão do microcontrolador desabilitados, o que exige que o sistema seja reiniciado sempre que a memória flash é gravada. O código executado pelo microcontrolador tem uma variável booleana utilizada para indicar que a gravação da memória flash iniciou. Caso ela tenha sido iniciada, todo o código de rotina deixa de ser executado para que o microcontrolador seja dedicado à gravação da memória e não ocorram erros de comunicação e de gravação. 


\subsubsection{Entradas Analógicas}

Na segunda versão da placa protótipo do controlador, utilizam-se circuitos de filtragem e redução de tensões dos sinais vindos dos sensores. Como observado nas figuras 45 e 46, são utilizados dois tipos de circuitos para as entradas analógicas, a primeira está preparada para sensores resistivos (termistores) e a segunda para sensores que enviam sinais em forma de tensão. No circuito da figura 45 não são utilizados divisores de tensão, devido a alimentação do amplificador operacional ser feita com 3,3V, portanto a tensão máxima na porta de saída nunca excederá a tensão máxima permitida pela entrada do microcontrolador. No circuito da figura 46 os divisores de tensão obrigam a tensão de saída a ficar abaixo do limite de 3,3 V.

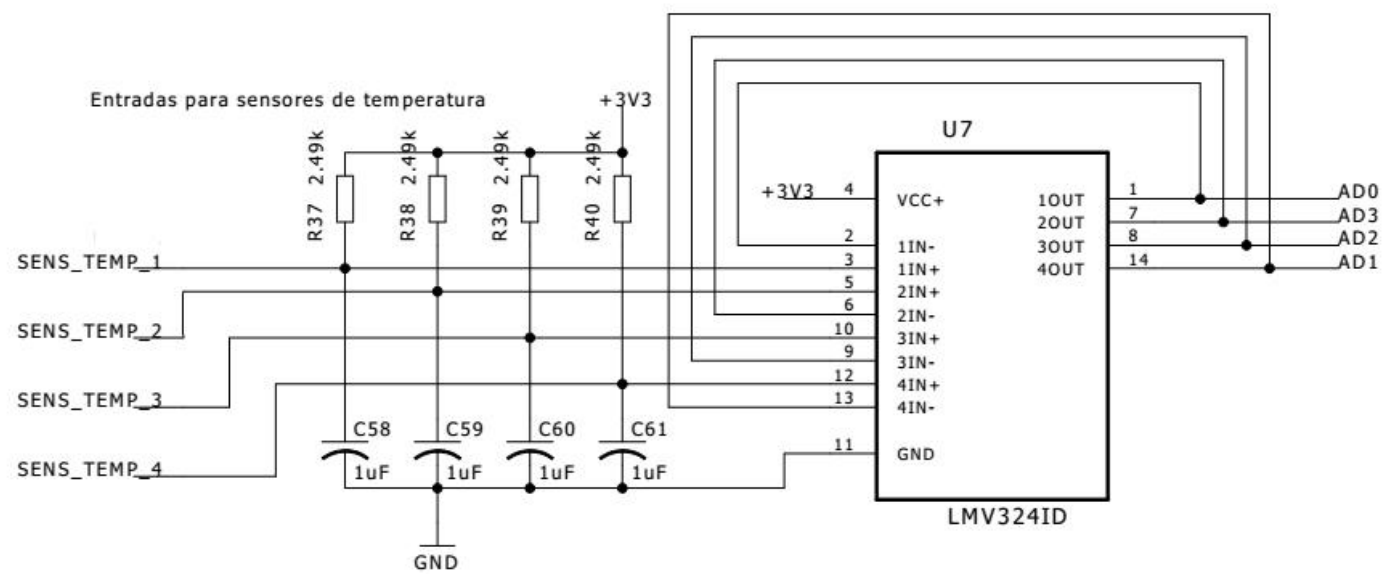

Figura 45 - Entradas analógicas para sensores resistivos.

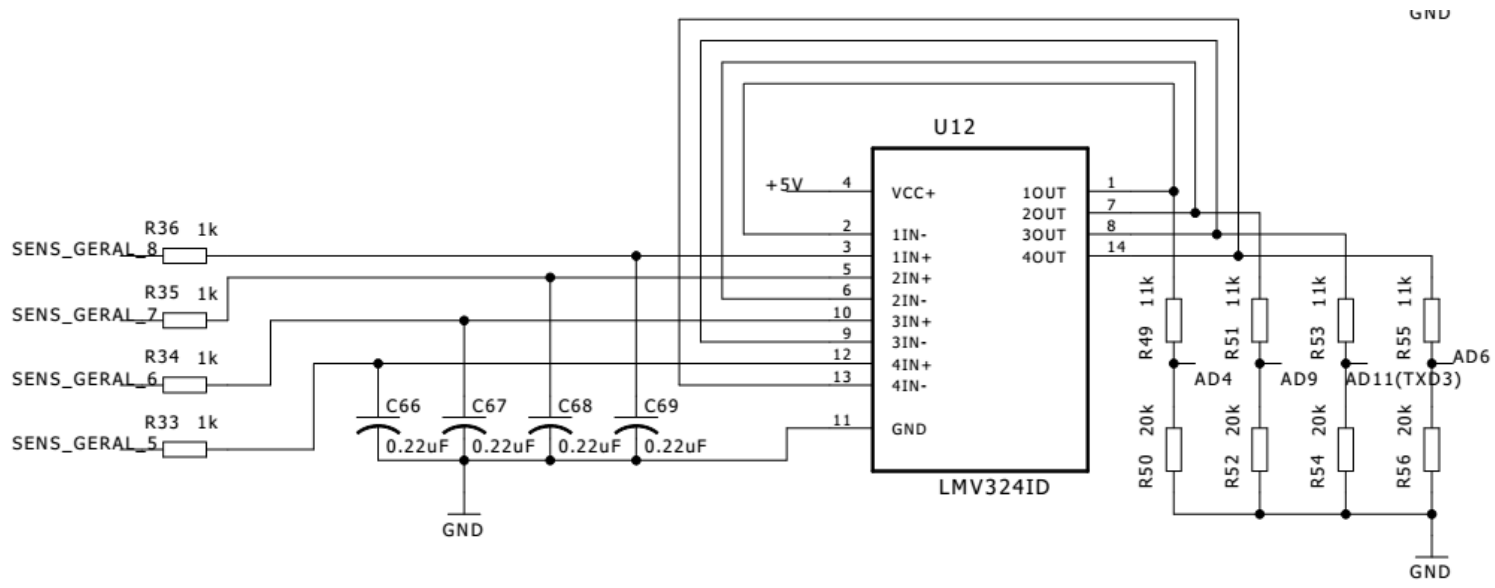

Figura 46 - Entradas analógicas. 
Apesar da importância da filtragem, optou-se por não considerar o estudo das características de ruídos e formas de atenuações como sendo um dos objetivos do trabalho. Para a função de filtragem, foram utilizados circuitos similares aos encontrados em um sistema comercial de código aberto chamado MegaSquirt ${ }^{\circledR}$ (BOWLING AND GRIPPO, 2014). São utilizados filtros RC nos dois tipos de entrada, no primeiro caso a frequência de corte é de $72 \mathrm{~Hz}$ e no segundo caso é de $720 \mathrm{~Hz}$.

Os dois tipos de circuitos utilizam amplificadores operacionais configurados como seguidores de tensão, para garantir alta impedância de entrada. O comportamento do filtro de $720 \mathrm{~Hz}$ é descrito no capítulo de ensaios.

\subsection{Códigos da TPU e do Microcontrolador}

Os códigos da TPU e do microcontrolador foram desenvolvidos para operar em conjunto. $\mathrm{O}$ microcontrolador realiza os cálculos relativos às técnicas de controle e envia comandos ao FPGA, que trabalha sincronizado em tempo real com o sistema mecânico controlado (figura 47).

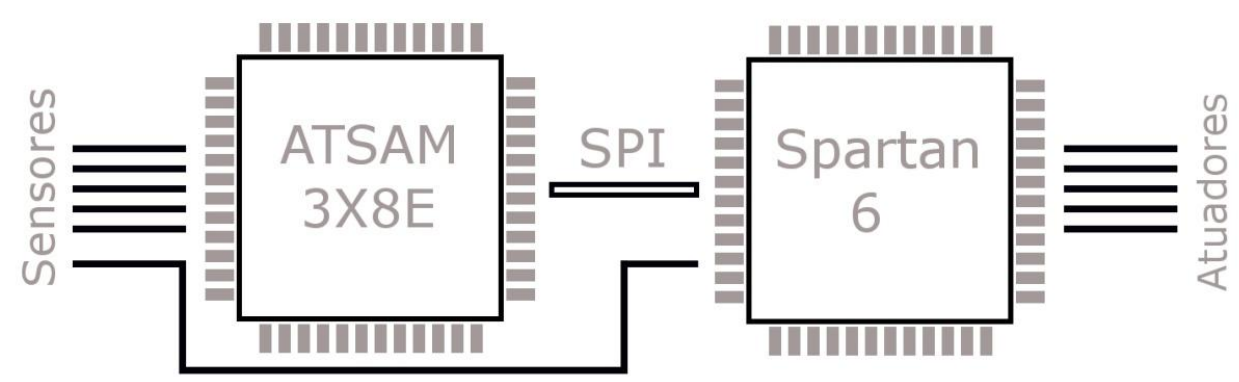

Figura 47 - Ligação entre Microcontrolador e FPGA.

Para o desenvolvimento do código do microcontrolador, foi utilizada a IDE básica do Arduino, com a aplicação das bibliotecas 'Wire' e 'SPI', que são bibliotecas padrão da IDE para comunicação I2C e SPI. A porta de comunicação I2C foi utilizada para comunicação entre o microcontrolador e a memória EEPROM. A TPU foi dividida em sete núcleos de código VHDL para aumento de flexibilidade no uso dos núcleos e fácil entendimento do código (figura 48). 


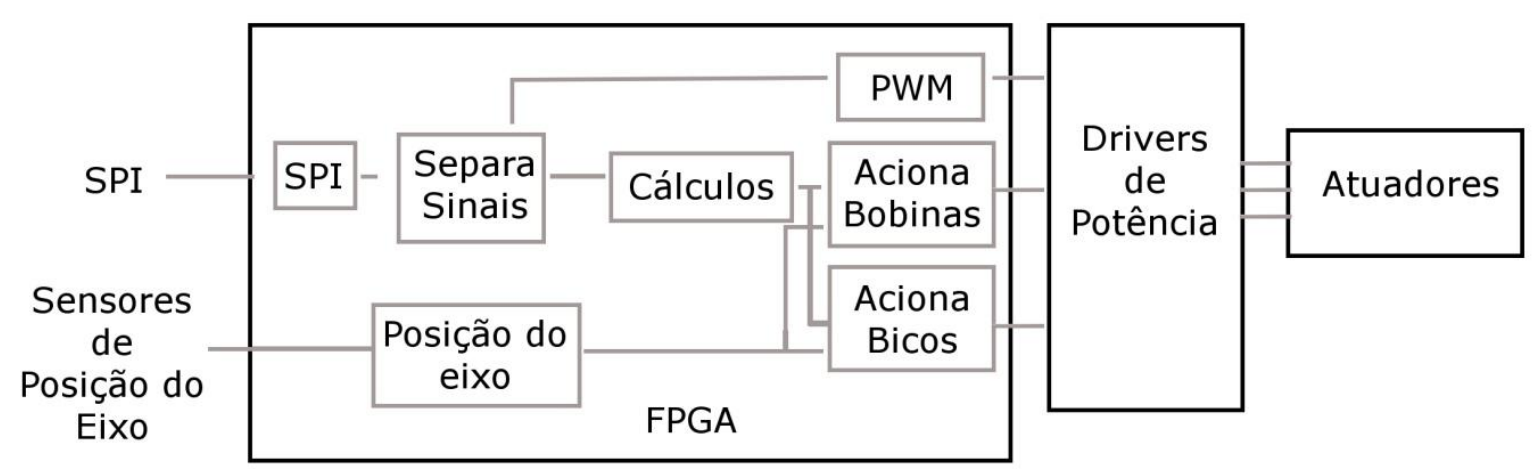

Figura 48 - TPU completa com periféricos.

\subsubsection{Rotinas de código do microcontrolador}

Basicamente, o microcontrolador executa as seguintes rotinas (figura 49):

- Inicialização do sistema: Rotina responsável por iniciar o sistema, configurando todos os periféricos a serem utilizados pelo microcontrolador e acessando a memória para carregar os registradores com os dados gravados pelo operador.

- Principal: Responsável pelos cálculos padrão, como interpolações de dados das tabelas estáticas, cálculos dos algoritmos de controle e envio de comandos ao FPGA.

- Comunicação: Rotina que interrompe a execução da rotina principal para executar funções de comunicação e gravação de dados nas memórias EEPROM e Flash.

Como observado na rotina de inicialização, o microcontrolador configura uma saída de $12 \mathrm{MHz}$ para ser conectada ao FPGA. Essa saída é ligada internamente ao circuito que trata o sinal de clock do microcontrolador e é utilizada pelo FPGA como base de tempo.

Os parâmetros carregados da memória são basicamente todos os parâmetros que podem ser configurados com o uso da IHM em JAVA. Entre eles, estão os valores que formam as tabelas de eficiência volumétrica e ponto de ignição e valores diversos do controlador, como referências e ganhos.

Um temporizador também é configurado ao final da rotina de inicialização. Ele é utilizado como base de tempo para os cálculos das rotinas de controle e pode ser configurado 
para gerar interrupções com o intervalo desejado. Para ensaios, o temporizador foi configurado para gerar interrupções a cada 0,2 segundo.

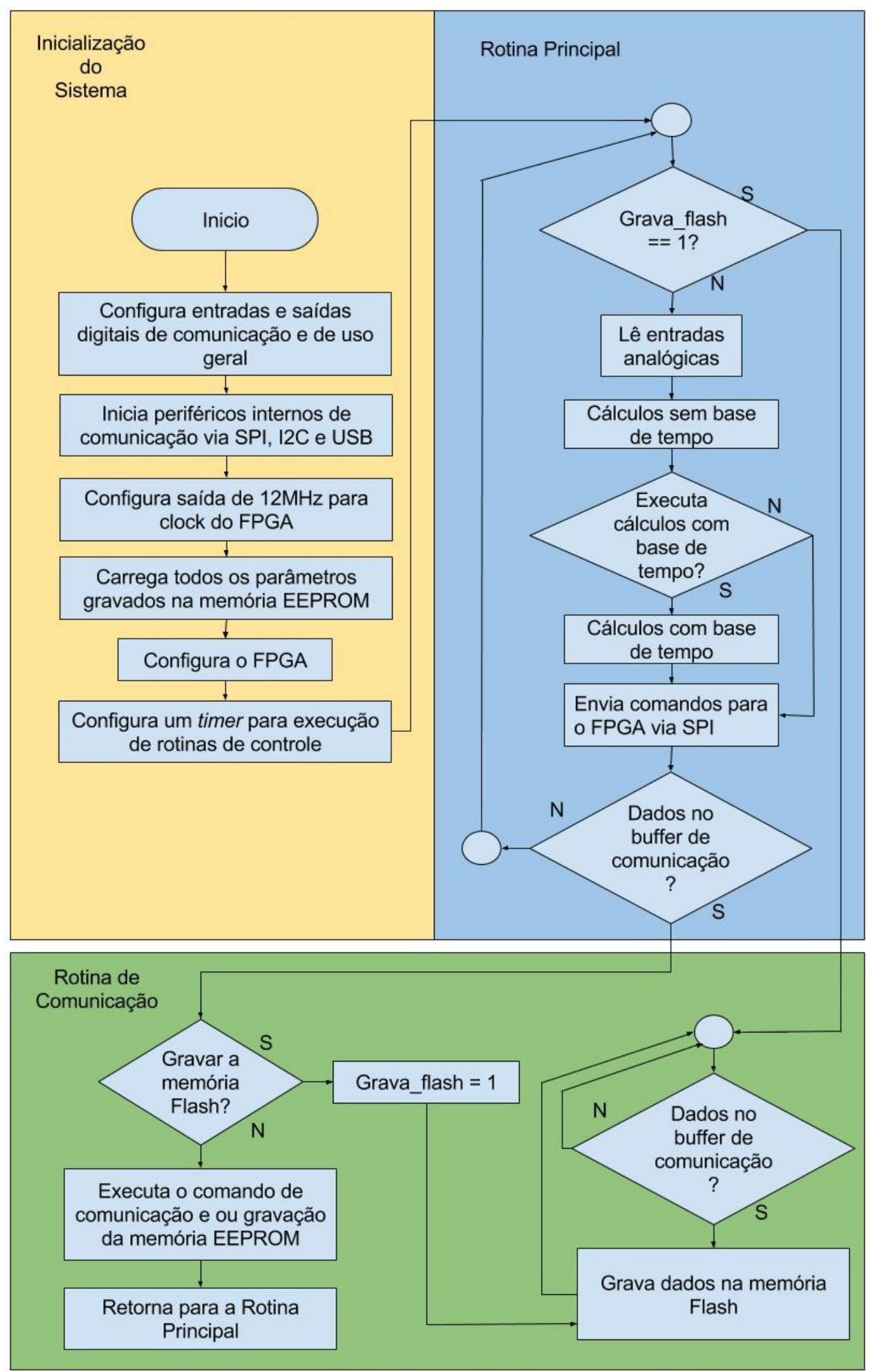

Figura 49 - Rotinas executadas pelo microcontrolador. 
Depois da rotina de inicialização, é executado o código da rotina principal, onde são realizados os cálculos com e sem base de tempo e as leituras das entradas digitais. Os cálculos sem base de tempo são os cálculos que não necessitam ser executados em períodos fixos. Como exemplo desses cálculos, pode-se citar o caso das interpolações das tabelas estáticas, esses valores variam de acordo com as leituras de velocidade angular do motor e dos valores de pressão enviados pelos sensores, e no protótipo são atualizados sempre que há alguma alteração nas variáveis de velocidade e pressão.

Geralmente, para que os controladores operem corretamente, é necessário que seja estabelecida a frequência com que o algoritmo de controle é executado. Esse valor de frequência é importante tanto durante o processo de projeto do controlador quanto em sua execução. Sempre que o timer destinado a gerar essa base de tempo gera uma interrupção, uma variável é carregada e indica ao programa principal que os cálculos com base de tempo devem ser executados.

Depois de todos os cálculos realizados, o microcontrolador envia ao FPGA todos os comandos atualizados. Na configuração padrão da TPU, o FPGA sempre retorna o valor do período total de uma volta do eixo virabrequim enquanto recebe dados pela SPI. Esses valores de período são convertidos para frequência pelo microcontrolador e utilizados para os cálculos. O próximo passo do código é a verificação do buffer de comunicação serial (buffer da USB). Ao receber dados no buffer, o microcontrolador entra na rotina de comunicação e verifica os primeiros bytes recebidos para identificar qual comando deve ser executado. Inicialmente, o código verifica se o comando enviado é para gravação de dados na memória Flash. Caso seja, o código entra no loop de gravação da memória Flash. Para sair da rotina, é necessário que o sistema seja reiniciado.

Caso o comando não seja para gravação de dados na memória Flash, ele pode ser dos seguintes tipos:

- Leitura de dados das entradas analógicas: O microcontrolador envia pela USB os valores atuais de todas as entradas analógicas.

- Leitura de dados da memória EEPROM: Envia dados específicos ou páginas da memória EEPROM.

- Gravação de dados na memória EEPROM: Grava dados específicos ou páginas da memória EEPROM. 


\subsubsection{Blocos da TPU}

Apesar de haver processamento em paralelo de todos os núcleos descritos para serem executados no FPGA, observa-se que o sistema opera com basicamente três rotinas (figura 50):

- Atualizações das posições de acionamentos: Rotina que recebe os comandos do microcontrolador via SPI e calcula as posições em que o FPGA deve acionar os atuadores. Essa rotina somente atualiza os valores de períodos e ciclo de trabalho no caso dos sinais recebidos para comando do núcleo de PWM.

- Estimação da posição do eixo: Rotina que utiliza os sinais vindos dos sensores de posição do eixo do motor e do sensor de fase para estimar a posição atual do eixo do motor dentro do ciclo de quatro tempos $\left(2\right.$ voltas $\left.=720^{\circ}\right)$. Realiza a detecção da falha de dente da roda e valida as leituras de períodos dos dentes.

- Acionamento de atuadores: É a rotina responsável por verificar a posição estimada do eixo e as posições de acionamento dos atuadores para comandá-los nos momentos corretos. 


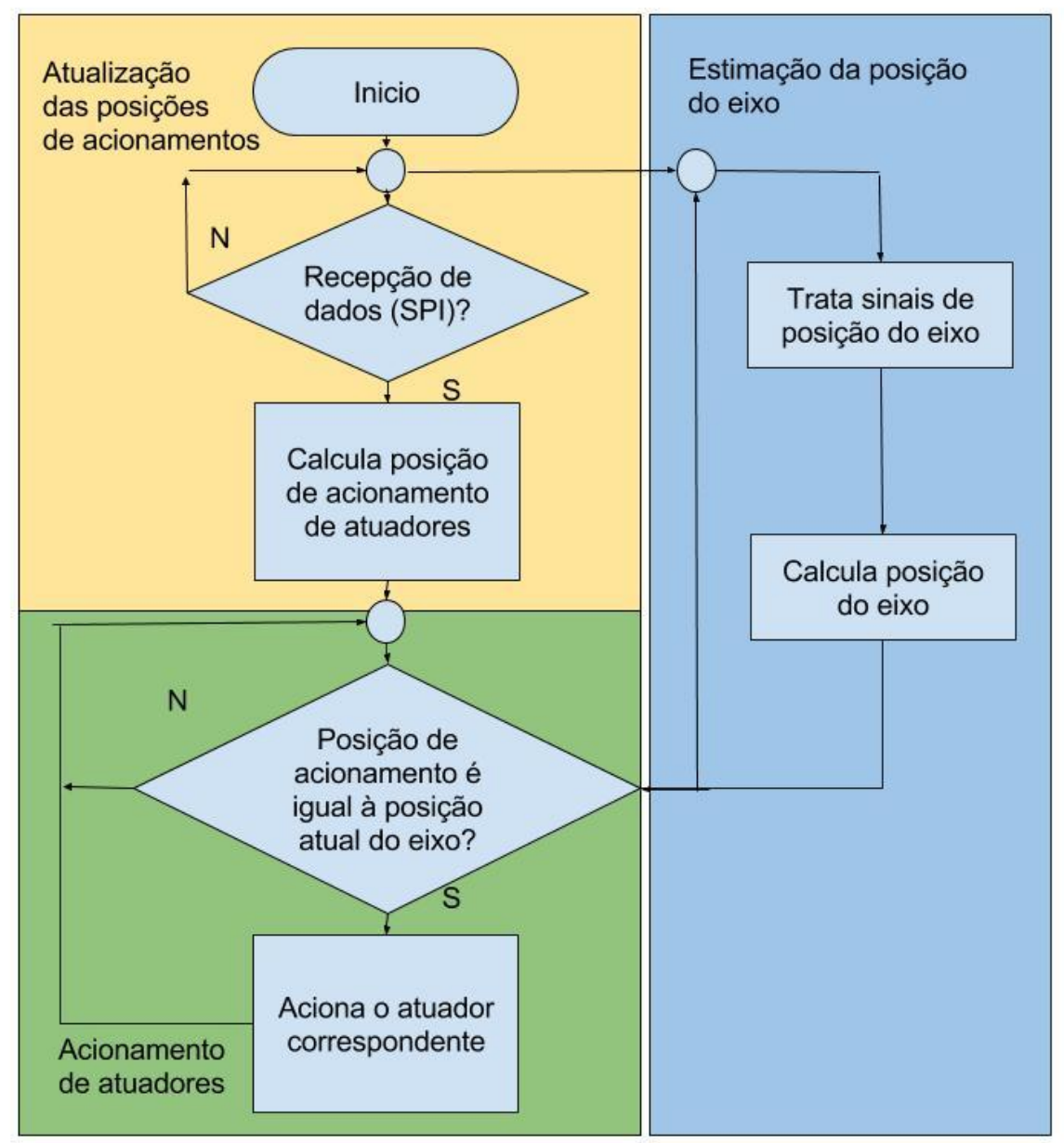

Figura 50 - Rotinas do FPGA.

A seguir, são apresentados os núcleos de códigos em VHDL que compõem a TPU. Para o desenvolvimento da discussão sobre a operação dos núcleos, consideram-se as seguintes características do sistema:

- Roda dentada com falha de 1 dente.

- Sensor de fase composto por um único ressalto localizado no eixo comando de válvulas e um sensor de relutância variável.

- Divisões de posicionamento variam de 0 a $2^{16}$ (65536). Cada divisão equivale a $720 \% 65536$ e variam de 0 a $720^{\circ}$. Como exemplo, considerando-se um comando de $4^{\circ}$ graus, são necessárias 364 divisões de posicionamento $\left(364 \times\left(\frac{720}{2^{16}}\right)=4\right)$.

É importante ressaltar que a roda dentada do sistema experimental apresenta uma falha de quatro dentes. $\mathrm{O}$ valor de um dente de falha foi escolhido para simplificar a apresentação do funcionamento dos núcleos descritos. 


\subsubsection{Posição do Eixo}

O núcleo de posição do eixo utiliza sinais do sensor de posição do eixo virabrequim e do sensor de fase, para estimar a posição atual do eixo virabrequim e disponibilizá-la em tempo real para os outros núcleos do sistema (figura 51).

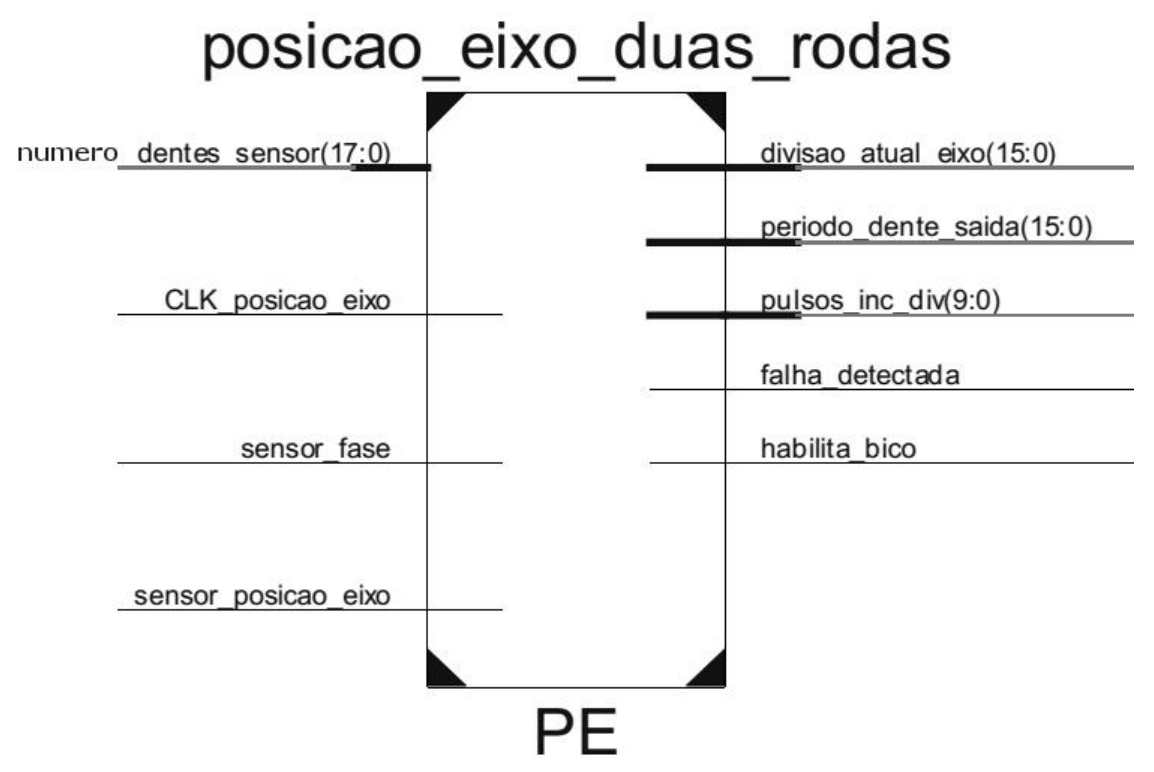

Figura 51 - Núcleo de estimação da posição do eixo

Para aumento da robustez, o núcleo utiliza intervalos de período para estimar se o período lido de um dente é consistente com o período do dente anterior. Na figura 52 pode-se observar esses intervalos descritos como i1, i2 e i3.

A marcação ilindica o intervalo onde deveria ocorrer a borda de subida da leitura de um dente comum do sistema. No entanto, nesse momento, está ocorrendo a falha de um dente da roda dentada, o que faz com que o sistema não detecte um dente e mantenha o período do dente anterior no sinal período_dente_validado (figura 53). 


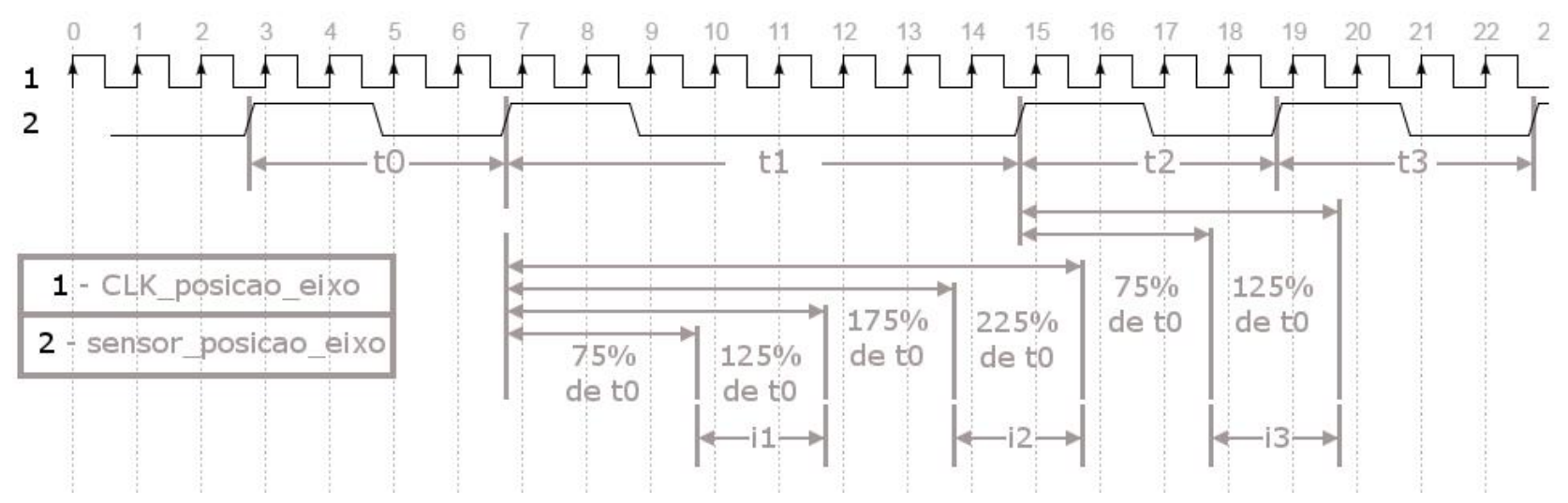

Figura 52 - Validação de leituras e detecção de falha.

Leituras com borda de subida que coincidem com leituras dentro do intervalo i2 indicam que a falha de dente da roda dentada foi encontrada. No intervalo i3, observa-se que o valor de período t2 está dentro do intervalo i3, o que indica que esse dente será validado baseado no período lido antes da leitura da falha de dente (período t1).

Os processos realizados pelo núcleo ocorrem da seguinte maneira:

- Com o auxílio de um contador, o sistema obtém o número de ciclos de clock que ocorrem entre as bordas de subida do sinal do sensor de posição do eixo, encontrando assim o período de duração de cada dente.

- O valor encontrado de número de ciclos é comparado com a contagem do dente anterior mais e menos aproximadamente $25 \%$ da quantidade de ciclos da contagem anterior (i1 - figura 52). Caso a leitura atual esteja dentro dessa faixa, o sistema valida a nova leitura e carrega o sinal período_dente_validado com o valor presente no sinal período_dente_atual (figura 53 - superior).

- Caso a leitura de períodos de dentes esteja fora do intervalo de validação para falha de dente (i2 - figura 53) ou para o dente normal (i1 ou i3 - figura 53), o sistema ignora essa leitura e mantém o sinal período_dente_validado com o valor anterior (figura 54 - superior). 

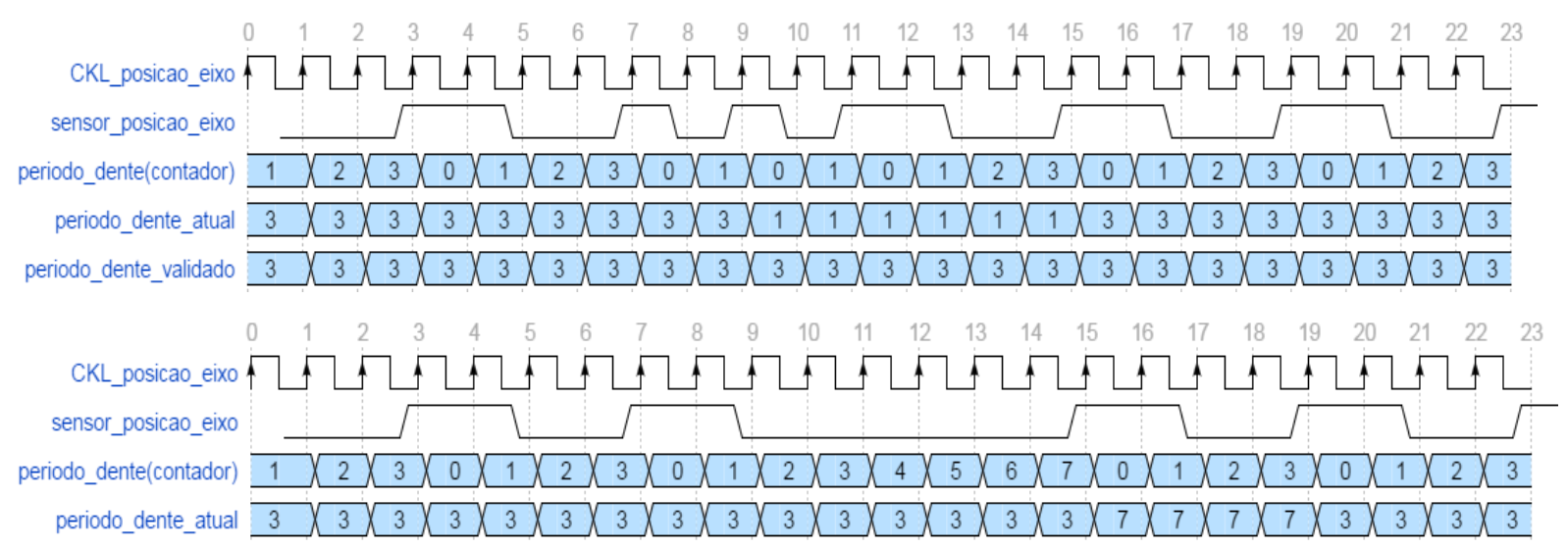

Figura 53 - Sinal de posição do eixo, defeituoso e normal.

- A nova leitura é disponibilizada para os núcleos de cálculos.

- A quantidade de ciclos medidos de um dente ( $c d$ ) é dividida pela quantidade teórica de divisões de posicionamento para um dente, ou seja, com $q d$ sendo a quantidade de dentes da roda fônica, encontra-se com a equação 5 a quantidade teórica de ciclos de clock necessárias para que o eixo do motor se movimente aproximadamente $0.01098^{\circ}$ (igual a $720^{\circ} / 2^{16}$ ).

$$
\text { pulsos_inc_div }=\frac{c d \times q d}{2^{16}}
$$

- O valor carregado em pulsos_inc_div é disponibilizado para os núcleos de cálculos.

- Paralelamente aos cálculos de validação dos períodos dos dentes, são realizados os cálculos para identificar se a nova leitura tem valor superior a $175 \%$ do valor da leitura anterior e inferior a $225 \%$ desse mesmo valor (i2 - figura 53). Caso a nova leitura esteja dentro dessa faixa, o núcleo considera que a falha de dente foi encontrada (considerando que seja falha de 1 dente) e uma flag interna é carregada com valor lógico ' 1 '.

- Caso a flag interna esteja carregada e o núcleo receba um sinal vindo do sensor de fase, o sistema entende que o eixo virabrequim realizou duas voltas completas e encerrou o ciclo. Nesse momento, o contador utilizado para indicar a divisão de posicionamento atual e a flag interna são zerados.

As faixas de tolerâncias utilizadas nas comparações são carregadas diretamente no código em VHDL do núcleo de estimação da posição do eixo. Portanto, caso a quantidade de falhas de dentes mude, o código deve ser adaptado. 


\subsubsection{SPI}

Devido à comunicação entre o microcontrolador e o FPGA ser realizada utilizando-se a porta de comunicação SPI, foi necessário o desenvolvimento de um núcleo em VHDL para receber e enviar dados via SPI. O núcleo desenvolvido somente opera como escravo e é responsável por receber e enviar dados de controle e monitoramento entre o microcontrolador e a TPU. Os dados recebidos via serial são dispostos em formato paralelo de 16 bits (figura 54). A descrição do núcleo foi realizada com base na descrição funcional da comunicação SPI encontrada em Atmel Corp (2015) e apresenta as seguintes portas de entrada e saída.

- CLK_SPI: Entrada para sinal de clock de $24 \mathrm{MHz}$, utilizado para detecção de bordas de subida e descida de outros sinais e para propagar os sinais dentro do núcleo.

- SCK (Serial Clock): Entrada de clock enviado pelo dispositivo SPI Mestre.

- SS (Slave Select): Entrada utilizada para habilitar a comunicação SPI.

- SDI (Serial Data In): Entrada serial de dados.

- SDO (Serial Data Out): Saída serial de dados.

- valor_lido: Sinal de 16 bits que disponibiliza os dados recebidos pela SPI para outros núcleos do sistema.

- valor_enviar: Entrada de 16 bits utilizada por outros núcleos para enviar dados para o mestre via a comunicação SPI.

- SS_rising_saida: Saída que indica o final da recepção de um dado de 16 bits.

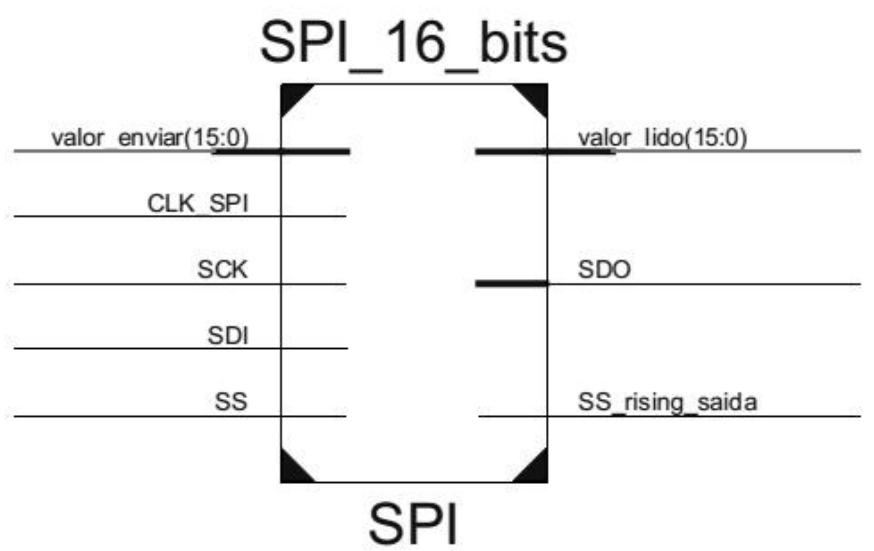

Figura 54 - Núcleo de comunicação serial. 
A recepção de dados é realizada através do pino SDI em pacotes de 2 bytes para recepção de dados de 16 bits (figura 55). É iniciada quando o nível lógico do pino SS (Slave Select) é alterado pelo mestre (microcontrolador) para zero. Nesse momento o mestre inicia o envio de pulsos de clock (SCK) e de dados (SDI).

A cada subida de clock, o nível lógico observado no pino SDI é estocado no registrador interno de leitura (dado_le) do núcleo. Depois do envio de um pacote de 8 bits, a comunicação é interrompida e reiniciada da mesma maneira para receber os outros 8 bits. Como visto na figura 55, o mestre inicia o envio com o bit mais significativo.

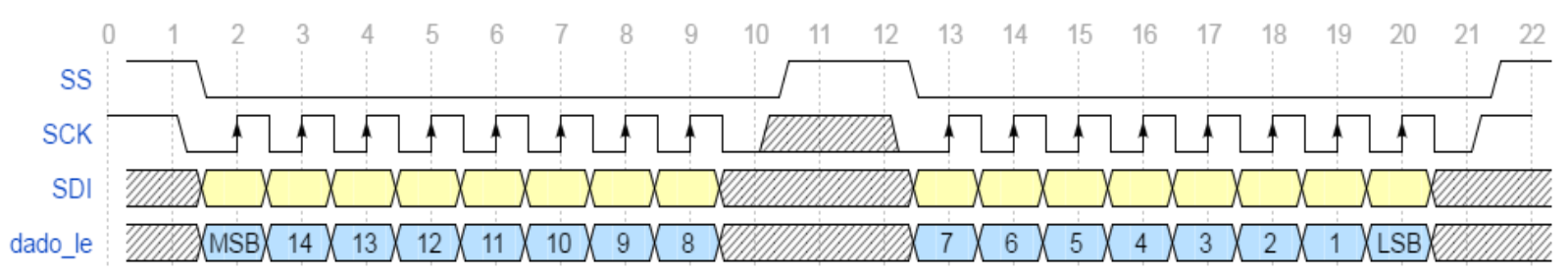

Figura 55 - Recebimento de dados via serial.

Depois de receber os 16 bits de dados, o sistema disponibiliza esse dado para que seja utilizado pelos outros núcleos que compõem o sistema. Isso é realizado carregando o sinal valor_lido com os dados armazenados em dado_le sempre que ocorre a última borda de subida do sinal SS (figura 56).

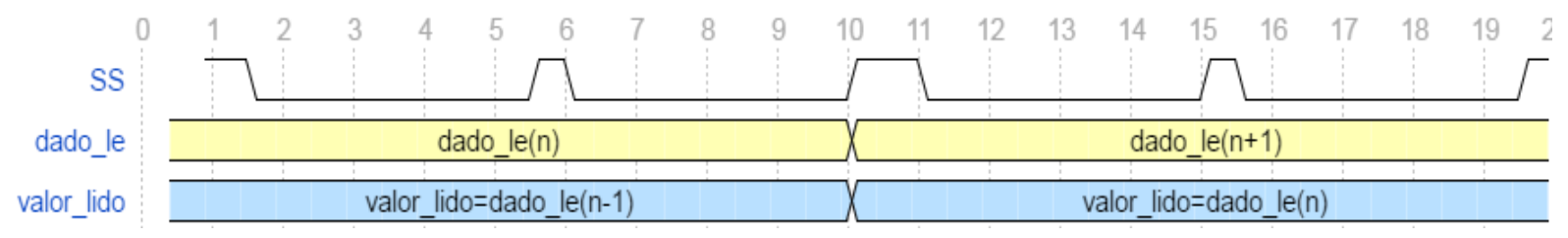

Figura 56 - Disponibilização de dados lidos.

O núcleo de comunicação SPI também tem a função de enviar dados do FPGA para o microcontrolador, o que é realizado utilizando-se o pino SDO. Durante um processo de envio de dados do mestre para o escravo, o núcleo SPI utiliza os pulsos de clock do mestre para enviar bits que são recebidos pelo mestre, utilizando-se o mesmo processo observado anteriormente na recepção de dados pelo núcleo SPI do FPGA. Os bits do sinal de 16 bits valor_enviar sendo enviados serialmente através do pino SDO de acordo com as bordas de subida do sinal de clock (SCK) são mostrados na figura 57. 


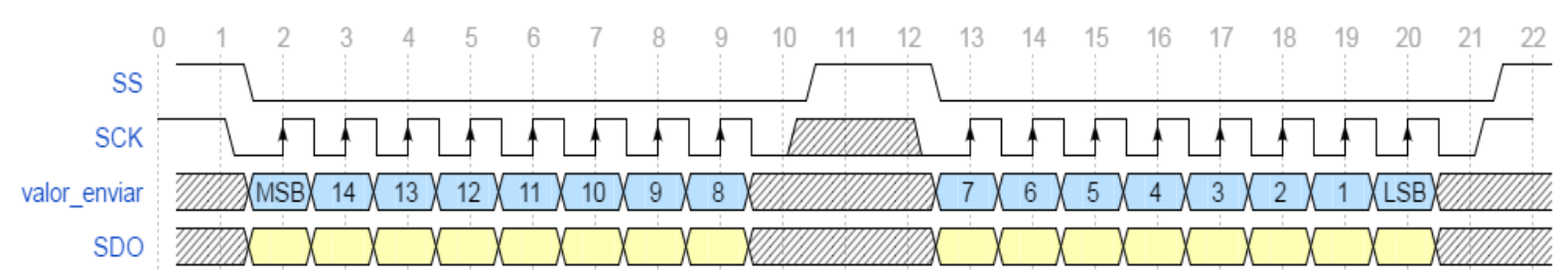

Figura 57 - Envio de dados via serial (Slave para Mestre).

A cada final de recebimento de dados, o núcleo envia um comando com duração de um ciclo de clock (24 MHz) pelo sinal "SS_rising_saida" que indica ao próximo núcleo o final de recebimento. No próximo ciclo de clock, o dado está pronto para ser coletado por núcleos adiante no processo.

\subsubsection{Separa Sinais}

O núcleo Separa Sinais é responsável por receber os dados do núcleo de comunicação serial e dispor em um buffer de dados (figura 58). Os primeiros 6 bits de cada dado recebido indicam a posição dos outros 10 bits no buffer de saída.

O núcleo apresenta sete tipos de sinais de saída:

- BICO_PER_X e BOBINA_PER_X: Sinais de 30 bits que indicam o número de ciclos de clock do FPGA necessários para gerar o período desejado de comando dos bicos injetores e bobinas. Estes valores são calculados pelo algoritmo de controle executado no microcontrolador.

- BOBINA_PER_DESENERG: Sinal de 30 bits que indica o número de ciclos de clock do FPGA necessários para gerar o período mínimo de desenergização das bobinas de ignição. Considerou-se que esse valor poderia ser único para todas as bobinas, devido à usual utilização de bobinas de mesmo modelo.

-BICO_POS_X e BOBINA_POS_X: Sinais de 16 bits que indicam as posições do eixo em que os atuadores devem ser desligados. O sistema considera que o valor $2^{16}$ equivale a $720^{\circ}$ (ciclo completo para motores 4 tempos), portanto os valores dos sinais ( 0 a $\left.2^{16}\right)$ equivalem a posições entre 0 e $720^{\circ}$. 


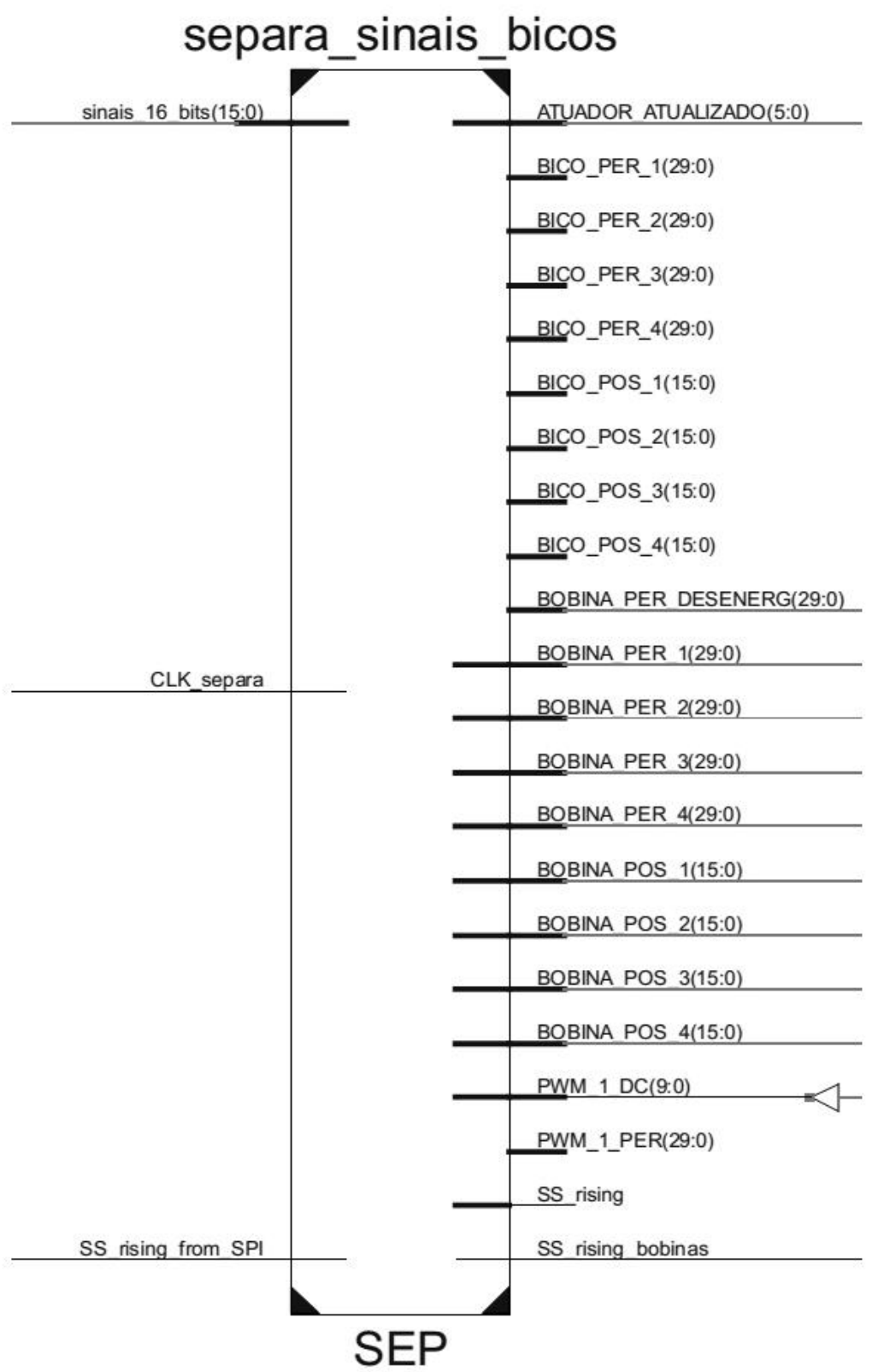

Figura 58 - Núcleo de separação de dados e buffer.

- PWM_X_PER: Sinal de 30 bits que indica o período máximo de cada ciclo de comando de PWM.

- PWM_X_DC: Sinal de 10 bits que representa o duty cycle do PWM.

Sinais de entrada:

- sinais_16_bits: Sinais a serem destinados para o buffer de acordo com os 6 bits mais significativos.

- CLK_separa: Entrada para sinal de clock de $24 \mathrm{MHz}$ utilizado como base de tempo . 
- SS_rising_from_SPI: Entrada que indica que um novo dado foi recebido pelo núcleo de comunicação SPI.

Havendo sinais com mais de 10 bits, fez-se necessária a divisão e envio do dado em partes de 10bits. O processo de atualização dos sinais é realizado da seguinte maneira:

- Inicialmente, os 10 bits de dados úteis são destinados à correta posição dentro de cada sinal no buffer, o que é executado somente quando o sinal SS_rising_SPI está em nível lógico '1' e ocorre uma subida de clock de CLK_separa (figura 60 - CLK_separa =1). Na figura 59 o sinal Parte_sinal_X é uma generalização e representa qualquer sinal de saída do núcleo.

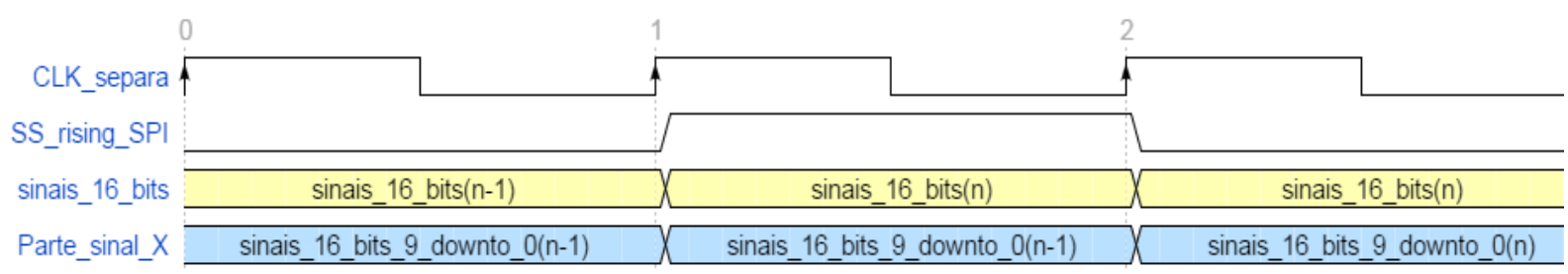

Figura 59 - Separação de dados.

- Depois de todos os bits de cada sinal serem atualizados, o sinal ATUADOR_ATUALIZADO é carregado com um valor que indica qual sinal foi completamente atualizado (figura $60-$ CLK_separa $=1$ ).

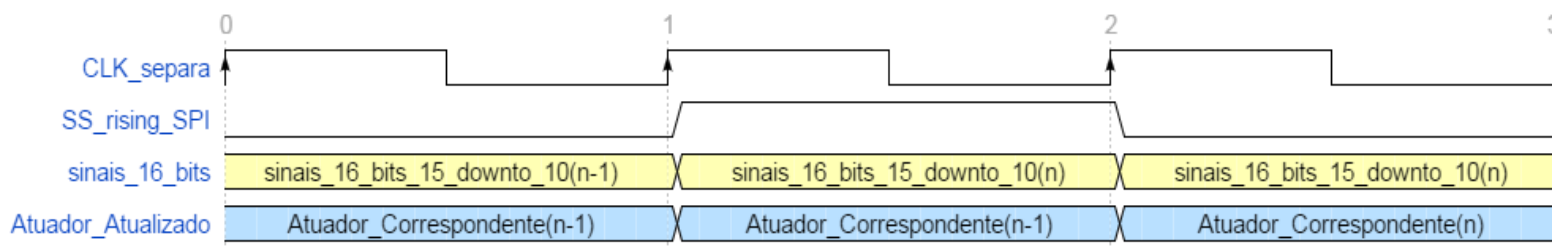

Figura 60 - Indicação de atuador completamente atualizado.

- O sinal SS_rising_(Bobina ou Bico) é colocado em nível lógico '1' durante um ciclo de clock, indicando aos núcleos seguintes que o sinal atualizado deve ser lido. Isso é realizado simplesmente com a propagação do sinal SS_rising_SPI (figura 61).

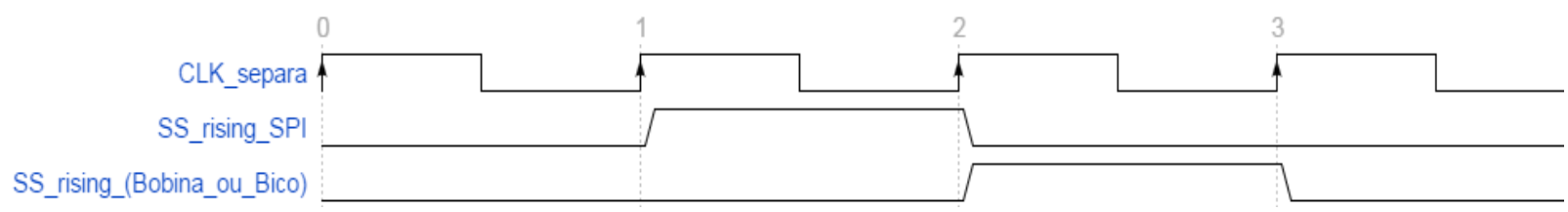

Figura 61 - Indicação de buffer atualizado. 


\subsubsection{Cálculos para acionamento dos atuadores}

No núcleo de cálculos (figura 62) são realizados os cálculos responsáveis por retornar os valores de instantes ideais em que as bobinas e os bicos devem iniciar, respectivamente, a energização e a injeção de combustível. O instante de início de acionamento é calculado com base na frequência de rotação do eixo do motor e no período de energização total da bobina. O uso do mesmo bloco para os cálculos de acionamento para bicos e bobinas é possível, considerando-se que os bicos são abertos de forma que a quantidade de combustível calculada pelo controlador tenha sido toda injetada antes do instante de abertura da válvula de admissão, o que por fim é semelhante ao processo de energização da bobina.

Como padrão, o sistema considera que a posição requerida em BOBINA_POS_X (BICO_POS_X) refere-se à posição em que as bobinas ou os bicos injetores seriam desativados. Então, o sistema calcula em que posição do eixo os atuadores devem ser ativados para que esses fiquem nesse estado durante o período indicado por BOBINA_PER_X

(BICO_PER_X) e ao final desse período o eixo esteja na posição indicada por

\section{BOBINA_POS_X (BICO_POS_X).}

As divisões de posicionamento do eixo em que os atuadores devem ser acionados são encontradas com o uso da equação 6.

$$
\begin{gathered}
\text { divisão_aciona } \sigma_{-} x=P O S_{-} X-d_{-} P O S \\
d_{-} P O S=\frac{\text { atuador } \_P E R_{-} X}{\text { pulsos_inc } c_{-} \text {div }}
\end{gathered}
$$

Sendo:

- divisão_aciona_x = Divisão de posicionamento em que o atuador deve ser ativado (divisão_aciona_bico ou divisão_aciona_bobina)

- POS_X = Divisão de posicionamento em que o atuador deve ser desativado (BOBINA_POS_X ou BICO_POS_X)

- atuador_PER_X = Período durante o qual o atuador deve permanecer ativo (BOBINA_PER_X ou BICO_PER_X) 


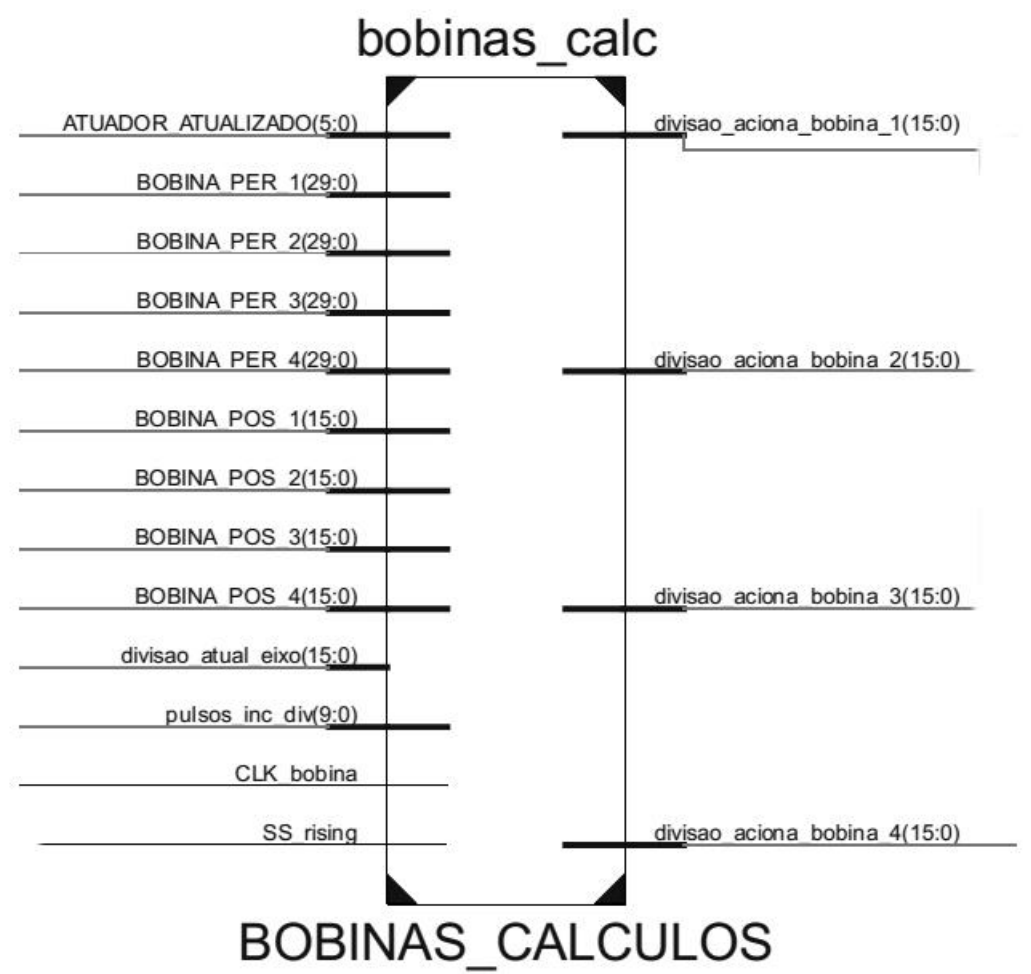

Figura 62 - Núcleo de cálculos de posição de acionamento de atuadores.

Com o auxílio de um ciclo teórico de $720^{\circ}$ (duas voltas do eixo virabrequim), observase um exemplo de comando da bobina de ignição para o cilindro 4 com avanço do ponto de ignição próximo a 0 graus na figura 63. Os comandos de outros atuadores não são representados na figura 63 mas seriam similares, estando defasados em torno de $180^{\circ}$ uns dos outros para um motor de quatro cilindros como considerado no exemplo.

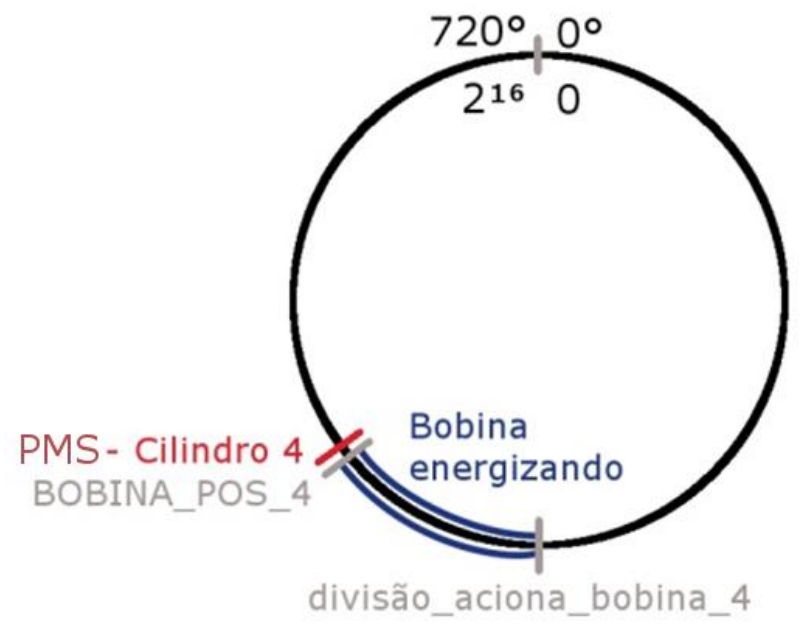

Figura 63 - Exemplo de comando de bobina de ignição 


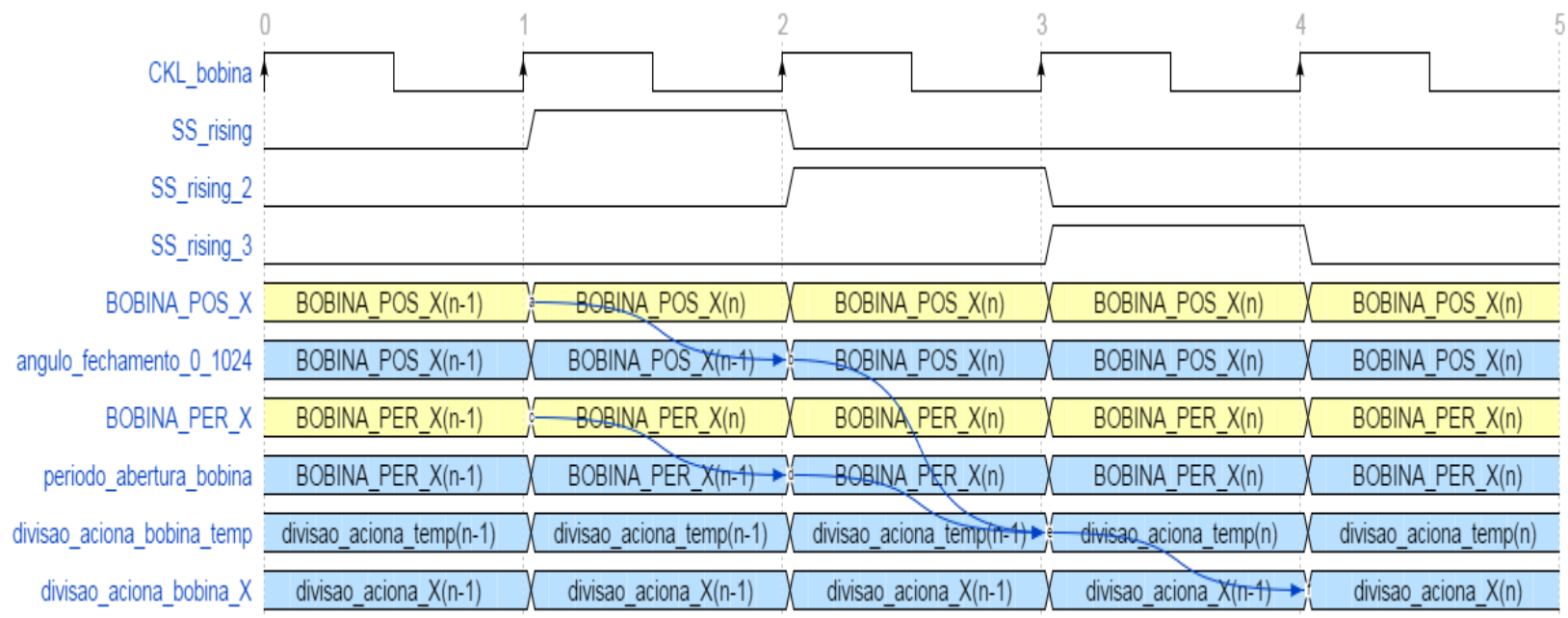

Figura 64 - Cálculo de posição ideal para inicio de energização da bobina.

Um ciclo completo de cálculos para comando de uma bobina é representado na carta de tempo da figura 65 . O ciclo completo é executado em quatro ciclos de clock. Inicialmente os sinais que indicam em que posição a bobina deve ser desenergizada e o período durante o qual a bobina deve ser energizada são carregados nos sinais internos do núcleo chamados

\section{ângulo_fechamento e período_abertura_bobina.}

No segundo ciclo de clock o circuito calcula em qual divisão de posição do eixo a bobina deve ser acionada para que ao final do período de energização a bobina seja desenergizada na posição correta do eixo do motor. Esse cálculo é executado da seguinte maneira:

- No primeiro ciclo de clock o circuito carrega os sinais internos com os valores a serem utilizados no próximo passo e já executa o cálculo de quantidade de divisões de posicionamento que seriam necessárias para total energização da bobina.

- Com a quantidade de divisões, o circuito faz uma comparação para saber se a quantidade de divisões necessárias é maior que a divisão de posicionamento indicada por BOBINA_POS_X.

- Caso a quantidade seja menor, o circuito subtrai essa quantidade de divisões do valor encontrado em BOBINA_POS_X, encontrando assim a divisão de posicionamento em que a bobina deve começar a ser energizada.

- Caso a quantidade seja maior, entende-se que o atuador deve ser acionado antes da divisão de posicionamento 0 . Portanto, se faz necessário inicialmente subtrair o valor encontrado em BOBINA_POS_X do valor de quantidade de divisões de posicionamento 
calculados no primeiro passo e depois subtrair o valor resultante da quantidade máxima de divisões de posicionamento.

- O valor de divisão de posicionamento calculado é carregado na saída

divisão_aciona_X, sendo que ' $\mathrm{X}$ ' indica em qual dos 4 atuadores esse sinal será utilizado.

\subsubsection{Comando das Bobinas e Bicos Injetores}

Os núcleos de comandos dos bicos injetores e das bobinas de ignição (figura 65) operam quase que da mesma maneira, exceto que para o comando de bobinas de ignição é necessário garantir um período mínimo de desenergização.

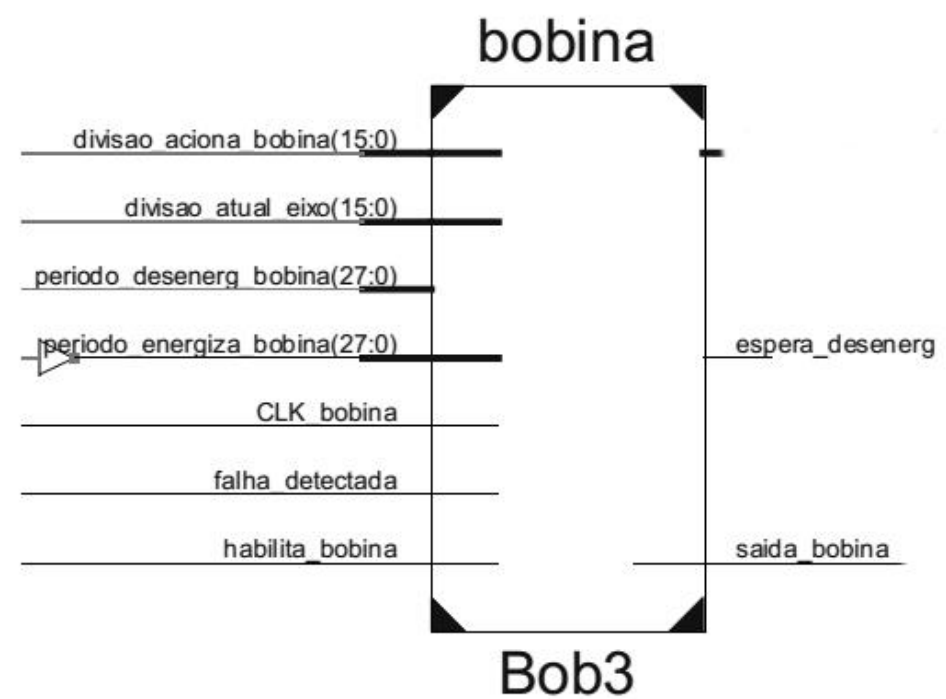

Figura 65 - Núcleo de comando de atuadores.

Os núcleos verificam a cada pulso de clock se a divisão de posicionamento atual é maior que a posição calculada pelo núcleo de cálculos (sinais divisão_aciona_bobina_x (bico)). No caso de essa condição ser verdadeira um contador é carregado com o valor do sinal BOBINAS_PER_X e BICOS_PER_X e inicia a contagem. Nesse mesmo momento, o atuador correspondente é ativado. O contador é decrementado utilizando o clock de $24 \mathrm{MHz}$. Quando ele é zerado os atuadores são desativados. 
No caso das bobinas de ignição, no momento em que as bobinas são desativadas, um contador auxiliar carrega o valor de BOBINA_PER_DESENERG, carrega a saída espera_desenerg com nível lógico ' 1 ' e inicia a contagem.

Durante o tempo em que uma das saídas espera_desenerg dos $n$ núcleos de comando de bobinas estiver acionada, uma lógica externa ao núcleo de acionamento inibe o comando das saídas de outros núcleos que comandam a mesma bobina. Esse mecanismo é necessário devido a não existir nessa biblioteca um núcleo de comando que aceita diversas posições de comando de atuadores. Portanto, mesmo utilizando-se uma única bobina para $m$ cilindros de um motor, ainda são necessários $m$ núcleos de comando.

Quando o período de um ciclo do eixo do motor se torna menor que o período de energização da bobina, deixa de existir um intervalo entre energizações e uma falha de desenergização e consequente falha de ignição do combustível na câmara de combustão ocorrem. O que o mecanismo inibidor das saídas de ignição faz é obrigar o sistema a sempre ter um período de desenergização da bobina, mesmo que a bobina não tenha tempo suficiente para energização total.

\subsubsection{PWM}

O núcleo PWM (figura 66) é responsável por gerar um sinal com largura de pulso variável (PWM). Realiza a divisão do valor do sinal período_máximo pelo valor do sinal duty cycle.

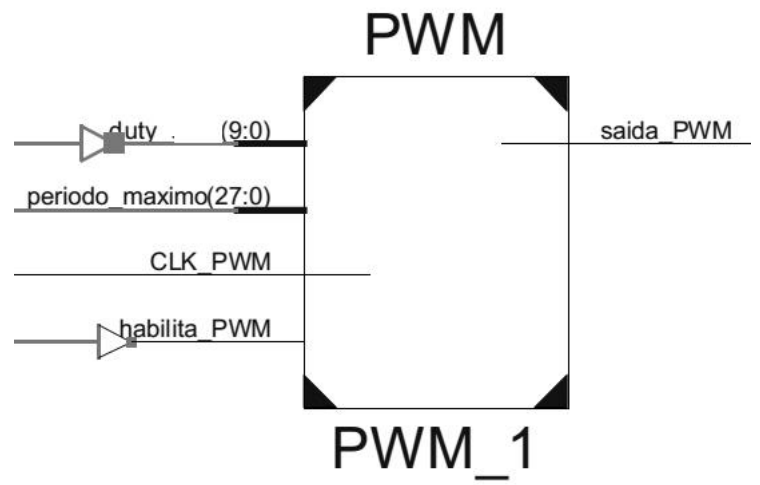

Figura 66 - Núcleo PWM. 
O valor de período_máximo é carregado em um contador que começa a ser decrementado. Quando o valor do contador se iguala ao valor do sinal duty cycle, a saída saída_PWM é colocada em nível lógico ' 1 ' até que o contador seja totalmente decrementado, momento em que a saída é colocada em nível lógico ' 0 ' e o contador é novamente carregado.

\subsection{Interface Homem Máquina}

Para a configuração do módulo durante a calibração e para a sintonia do controlador, mostrou-se necessário o desenvolvimento de uma interface. Essa interface permite que as configurações possam ser feitas através de uma comunicação USB entre o controlador e a máquina executando o supervisório. Para desenvolvimento da IHM (Interface HomemMáquina), foi escolhida a linguagem de programação JAVA, por ser totalmente livre e apresentar grande suporte e opções de bibliotecas. O painel principal com uma aba de tabela de eficiência volumétrica pode ser vista na figura 67.

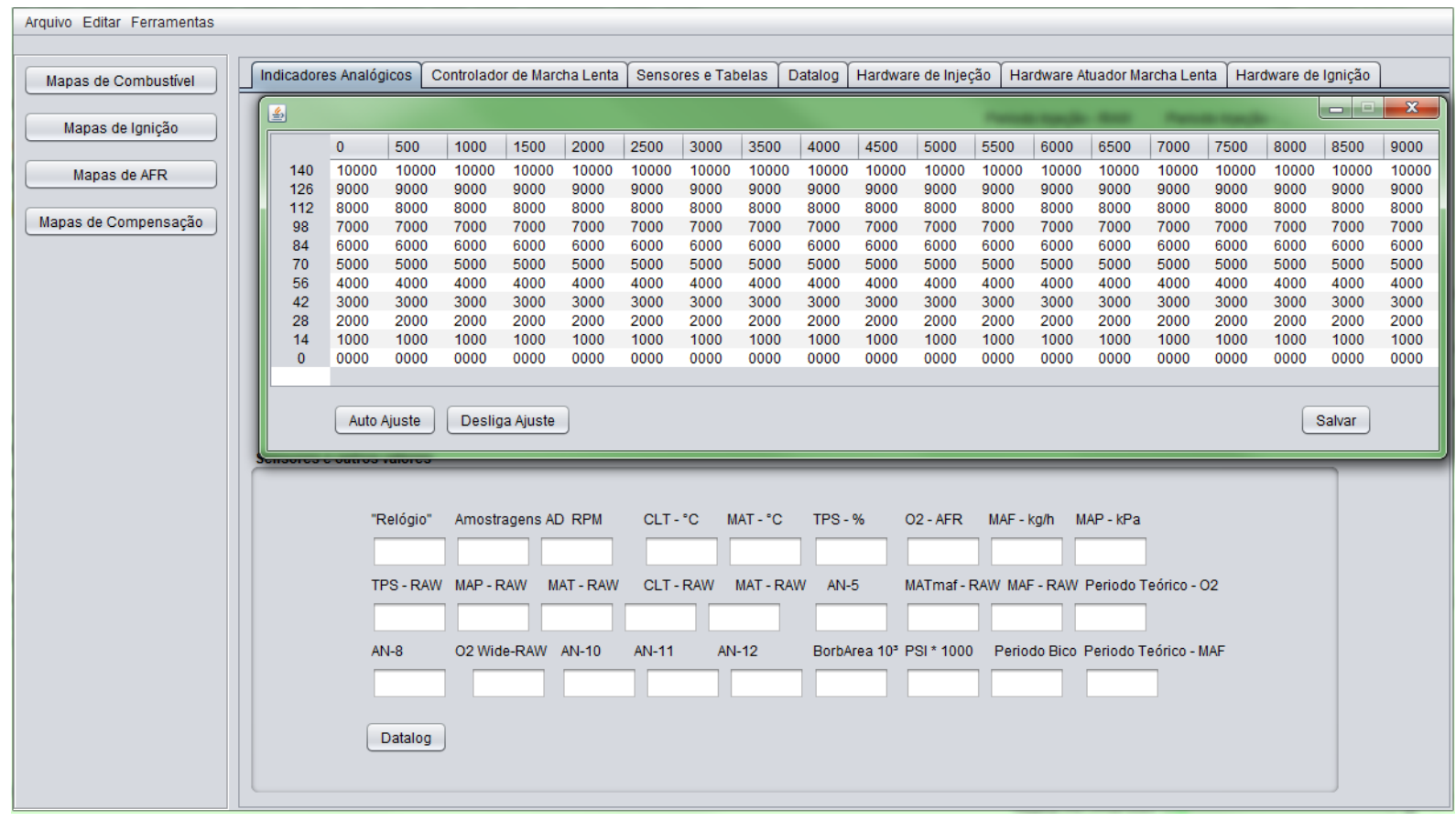

Figura 67 - IHM em JAVA

A IHM apresenta as seguintes funções: 
- Gravação das tabelas de eficiência volumétrica e ponto de ignição, tendo como eixos os valores de pressão absoluta dentro do coletor de admissão e velocidade angular do eixo do motor (figura 68).

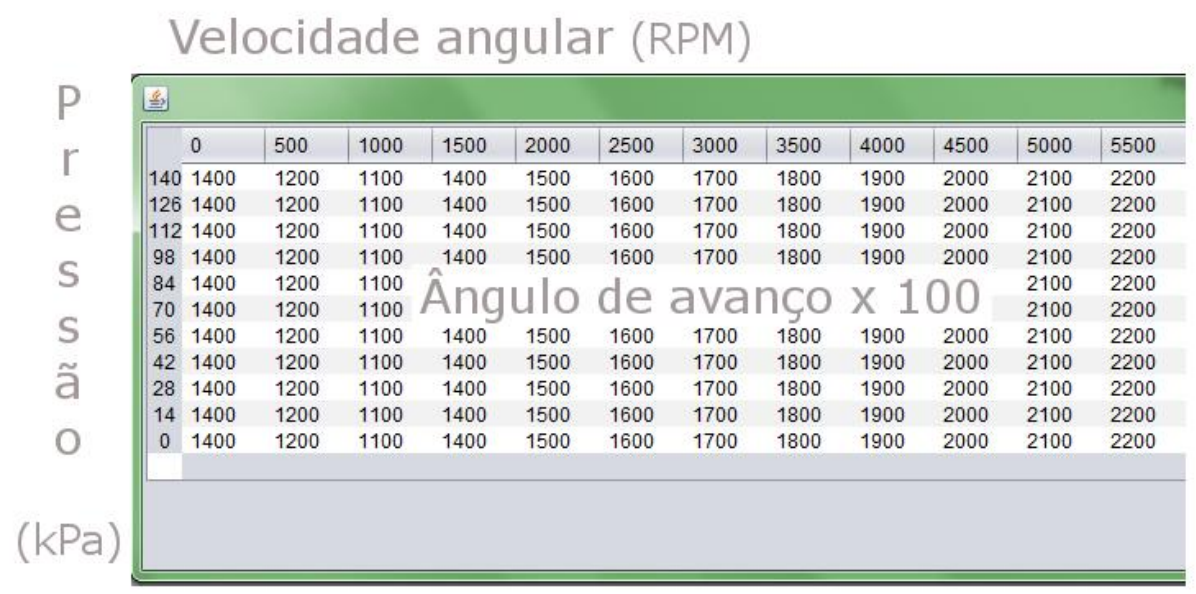

Figura 68 - Tabela de avanço de ponto de ignição.

- Gravação das tabelas que relacionam a tensão lida pelo microcontrolador com a variável de pressão do sensor (figura 69).

- Gravação das tabelas que indicam o eixo x (velocidade angular) das tabelas de eficiência volumétrica e ponto de ignição (figura 69).

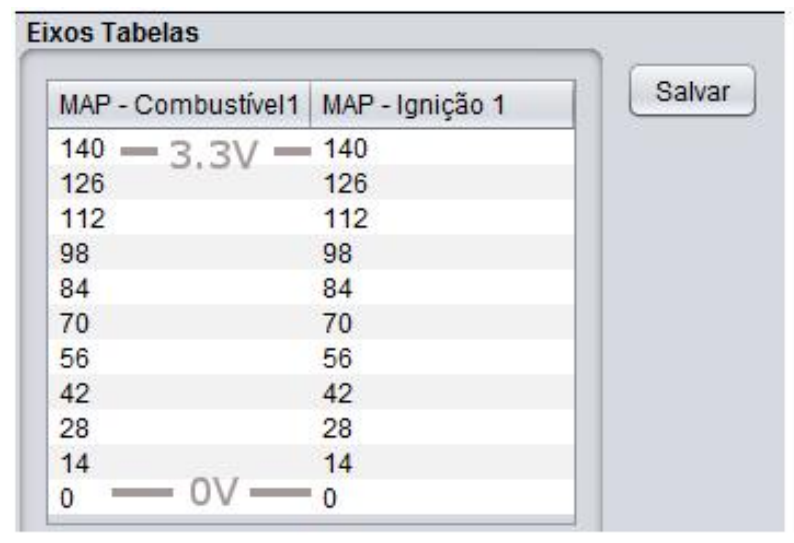

\begin{tabular}{|l|l|l|}
\hline RPM - Combustiv... & RPM - Ignição 1 \\
\hline 9000 & 9000 \\
8500 & 8500 \\
8000 & 8000 \\
7500 & 7500 \\
7000 & 7000 \\
6500 & 6500 \\
6000 & 6000 \\
5500 & 5500 \\
5000 & 5000 \\
4500 & 4500 \\
4000 & 4000 \\
3500 & 3500 \\
3000 & 3000 \\
2500 & 2500 \\
2000 & 2000 \\
1500 & 1500 \\
1000 & 1000 \\
500 & 500 \\
0 & 0 \\
\end{tabular}

Figura 69 - Tabelas de configuração dos eixos das tabelas de avanço de ignição e de eficiência volumétrica. 
- Monitoramento dos sensores e geração de arquivo com os valores dos sensores em função do tempo.

- Conexão via comunicação USB com o microcontrolador.

Através da comunicação serial, o supervisório envia comandos para carregar a memória EEPROM 24LC256 com os dados utilizados pelo microcontrolador. Esses dados são carregados em cada inicialização do sistema e sempre que algum dado da memória é alterado durante a operação do sistema.

As tabelas de eficiência volumétrica e de ponto de ignição são tabelas utilizadas, respectivamente, para o controle da quantidade de combustível injetado no motor e para o controle do ponto de ignição, estando as duas tabelas em função da pressão absoluta dentro do coletor de admissão e da velocidade angular do eixo do motor. 


\section{$7 \quad$ Ensaios realizados}

Nesta seção são apresentados os ensaios realizados para verificar o funcionamento do sistema desenvolvido. Para medições foi utilizado um osciloscópio Agilent da série 3000 de $70 \mathrm{MHz}$ e com dois canais.

\subsection{Entradas analógicas}

Três características das entradas analógicas foram testadas:

- Operação do seguidor de tensão.

- Tensão máxima de saída do divisor de tensão.

- Atenuação do filtro.

Os ensaios de tensão de saturação da entrada e de tensão máxima observada no divisor de tensão foram realizados aplicando-se uma onda senoidal de $120 \mathrm{~Hz}$ em uma das entradas analógicas com filtro RC com frequência de corte de $720 \mathrm{~Hz}$.

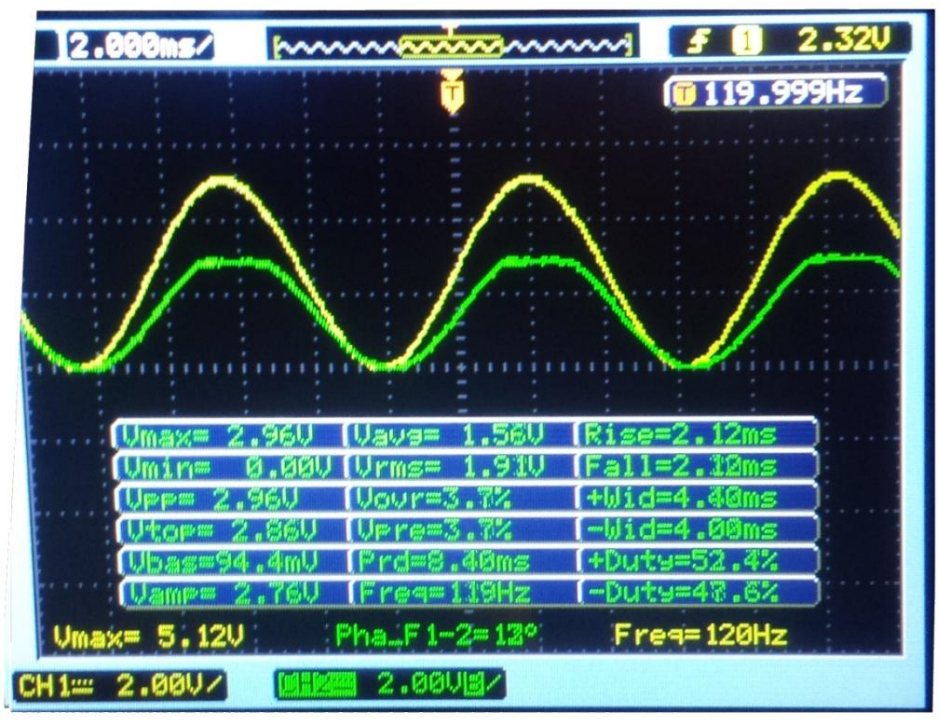

\section{Figura 70 - Entrada de sinal acima do nível de saturação.}

Utilizando um sinal de entrada com pico de $5,12 \mathrm{~V}$, a tensão de saída do divisor de tensão saturada é de 2,96 V (figura 70). A tensão de 2,96 V não permite o aproveitamento máximo de resolução da entrada analógica do microcontrolador. No entanto, é considerado como aceitável devido às tolerâncias de componentes do circuito que podem fazer essa tensão 
excursionar levemente para valores superiores ou inferiores a esse, podendo se aproximar demais do limite de $3.3 \mathrm{~V}$.

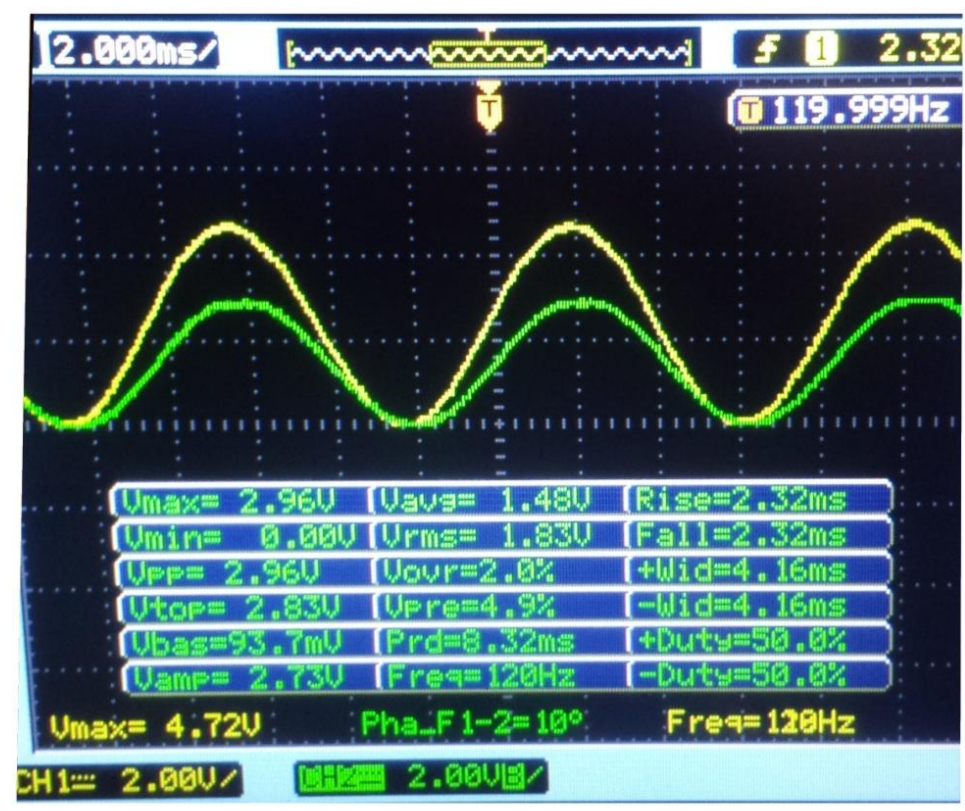

Figura 71 - Sinal de entrada no limite de saturação

O limite de saturação do sinal de entrada é de aproximadamente $4.7 \mathrm{~V}$ com a alimentação do amplificador operacional de 5V. Essa tensão foi obtida com a redução da tensão de pico do sinal de entrada até que o sinal de saída do divisor de tensão apresentasse uma redução de tensão de pico (figura 72). O ganho do circuito em função da frequência foi levantado aplicando-se sinais senoidais com frequências de 60,120,240,480,960,1900 e 3800 Hz. A tabela 3 mostra os valores de ganhos observados nas medições.

Tabela 3 - Ganhos do filtro de primeira ordem em função da frequência. Frequência do sinal $(\mathrm{Hz}) \quad$ Ganho $(\mathrm{dB})$

480 
Considerando que a frequência de corte de um filtro RC é obtida por:

$$
f_{c}=\frac{1}{2 \times \pi \times R \times C}
$$

Onde:

$f_{c}=$ Frequência de corte do filtro $(-3 \mathrm{~dB})$.

$\mathrm{R}=$ Resistência em Ohms do resistor do filtro.

C = Capacitância em Farads do capacitor do filtro.

$\pi=$ Constante igual a 3,14 .

De acordo com a equação 8 a frequência de corte do circuito deve estar em torno de $720 \mathrm{~Hz}$, o que é observado na figura 72, onde o resultado experimental encontrado na tabela 3 está plotado juntamente com a resposta de um modelo teórico do filtro utilizado.

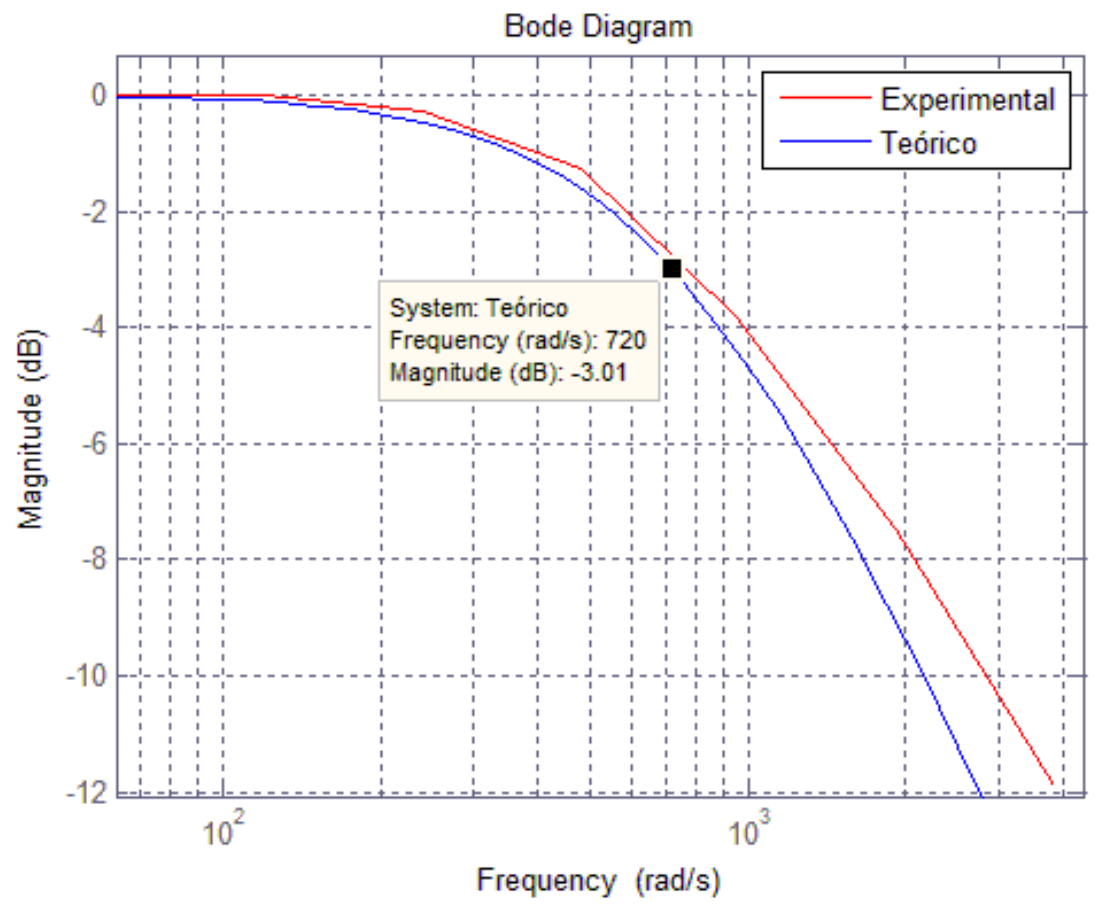

Figura 72 - Diagrama de bode do ganho do circuito de entrada em função da frequência do sinal.

As formas de onda medidas experimentalmente podem ser observadas na figura 73 $\boldsymbol{a}, \boldsymbol{b}, \boldsymbol{c}, \boldsymbol{d}, \boldsymbol{e}$ e $\boldsymbol{f}$ que representam respectivamente os sinais com entradas de 60, 120, 240, 480, 960, 1900 e $3800 \mathrm{~Hz}$. 

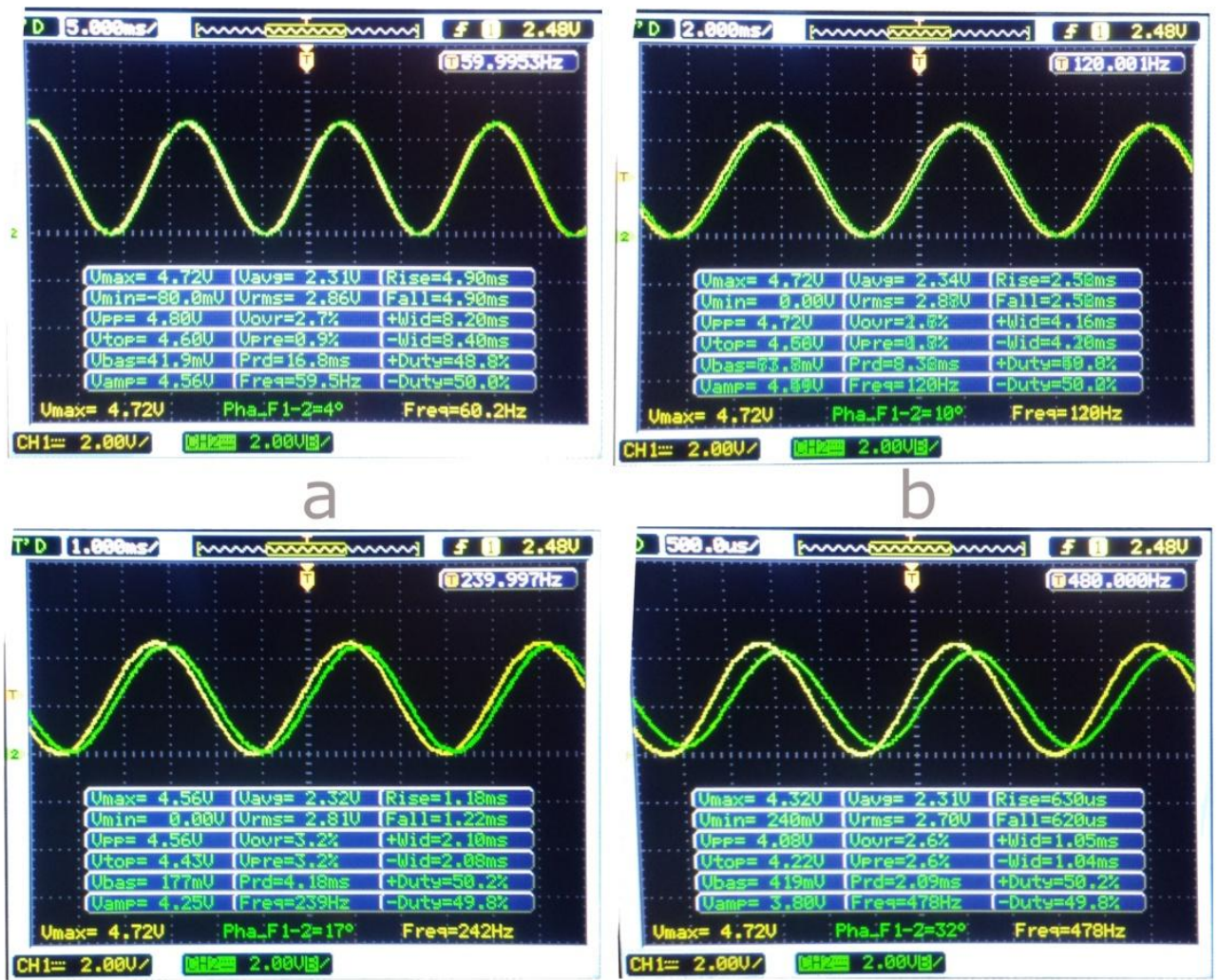

\section{C}

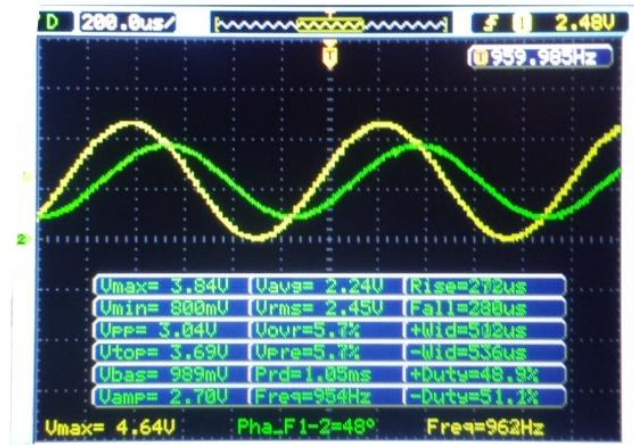

CHII 2.0007 대: 2. 2.600:

e

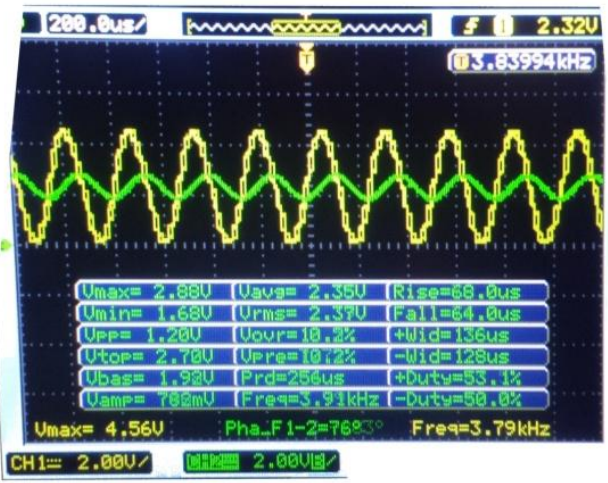

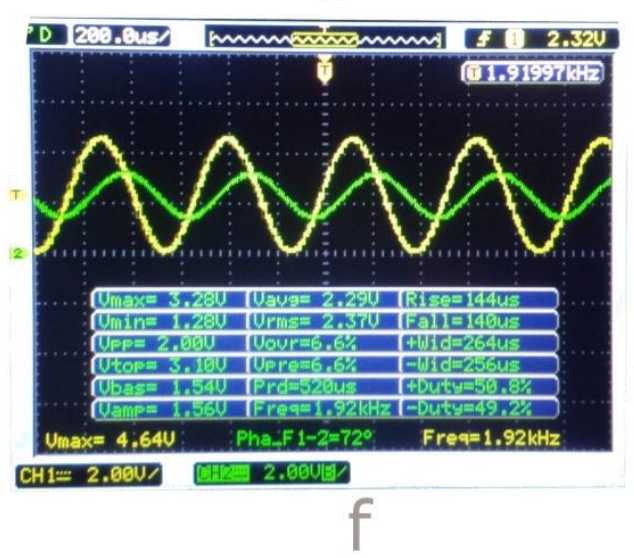

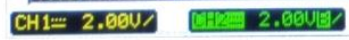

CH1 $=2.6004$ CH2 $2.600 \mathrm{~B}$

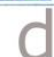

Figura 73 - Atenuação dos sinais de entrada. 


\subsection{Operação básica dos núcleos}

Os primeiros ensaios da descrição dos núcleos em VHDL foram realizados com o simulador do programa ISE. Utilizando a primeira placa protótipo, essa versão do código foi carregada no FPGA para ensaios de funcionamento de cada bloco separadamente. Para acesso aos valores de sinais internos do FPGA, foi utilizada a comunicação SPI. Portanto, o núcleo de comunicação SPI foi o primeiro a ser testado. Os ensaios foram realizados programando o código para gerar um eco do que era enviado pelo microcomputador ao FPGA (figura 74).

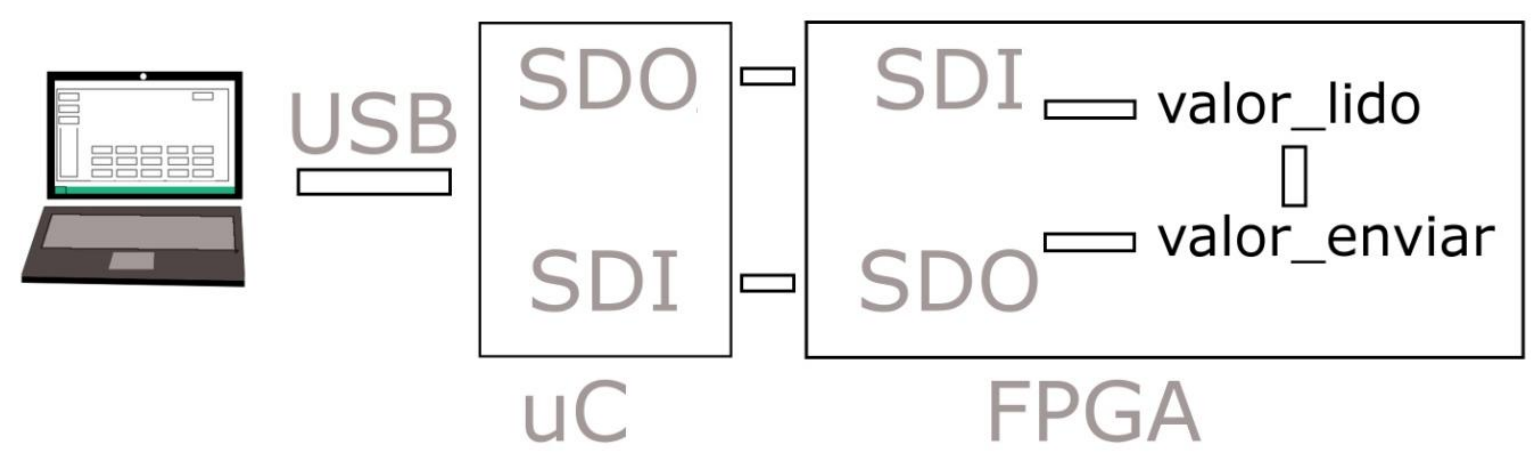

Figura 74 - Circuito programado para gerar um eco na linha de comunicação SPI.

Foram iniciados, depois de constatado o funcionamento adequado do núcleo SPI, os ensaios e correções de código do núcleo de separação de dados. Como forma de ensaios, os sinais separados pelo núcleo foram conectados ao núcleo SPI, permitindo assim o monitoramento do que estava sendo separado pelo núcleo e se os valores estavam corretos. $\mathrm{O}$ núcleo de cálculos foi testado seguindo a mesma metodologia dos outros núcleos.

Para que fosse possível realizar os ensaios dos núcleos de comando de bicos injetores e de bobinas de ignição, primeiramente foi necessário garantir que a operação do núcleo de estimação da posição do eixo estava correta. Os ensaios foram realizados utilizando-se um núcleo em VHDL para simulação dos sinais da roda dentada e do sensor de fase. A simulação dos sinais é realizada com a geração de dois sinais de onda quadrada. O sinal referente à roda dentada é formado por uma carreira de pulsos seguido de uma falha desses pulsos. Já o sinal do sensor de fase é um único pulso gerado a cada dois ciclos completos de pulsos do sinal da roda dentada do eixo virabrequim (figura 75). Considerando a simulação de uma roda dentada 
de 60 dentes com quatro falhas de dente, o sinal gerado para ensaios apresenta quatro falhas de pulso a cada 56 pulsos normais.

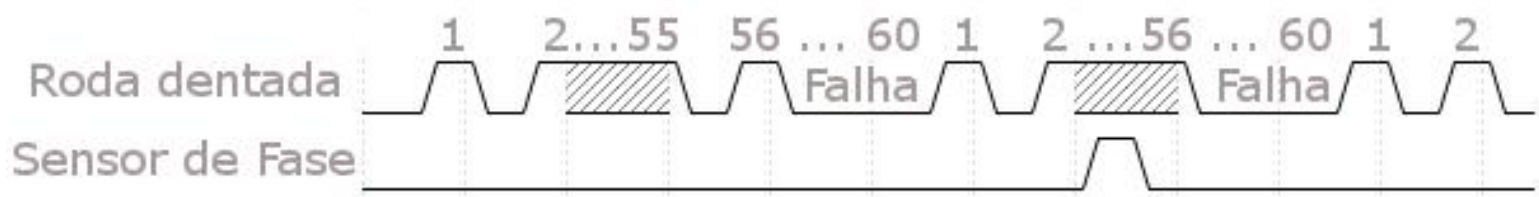

Figura 75 - Sinais da roda dentada do virabrequim e do sensor de fase.

Os sinais gerados pelo núcleo foram injetados nas entradas do circuito integrado MAX9926, que, por sua vez, está conectado às entradas destinadas aos sensores de posição do eixo no FPGA (figura 77).

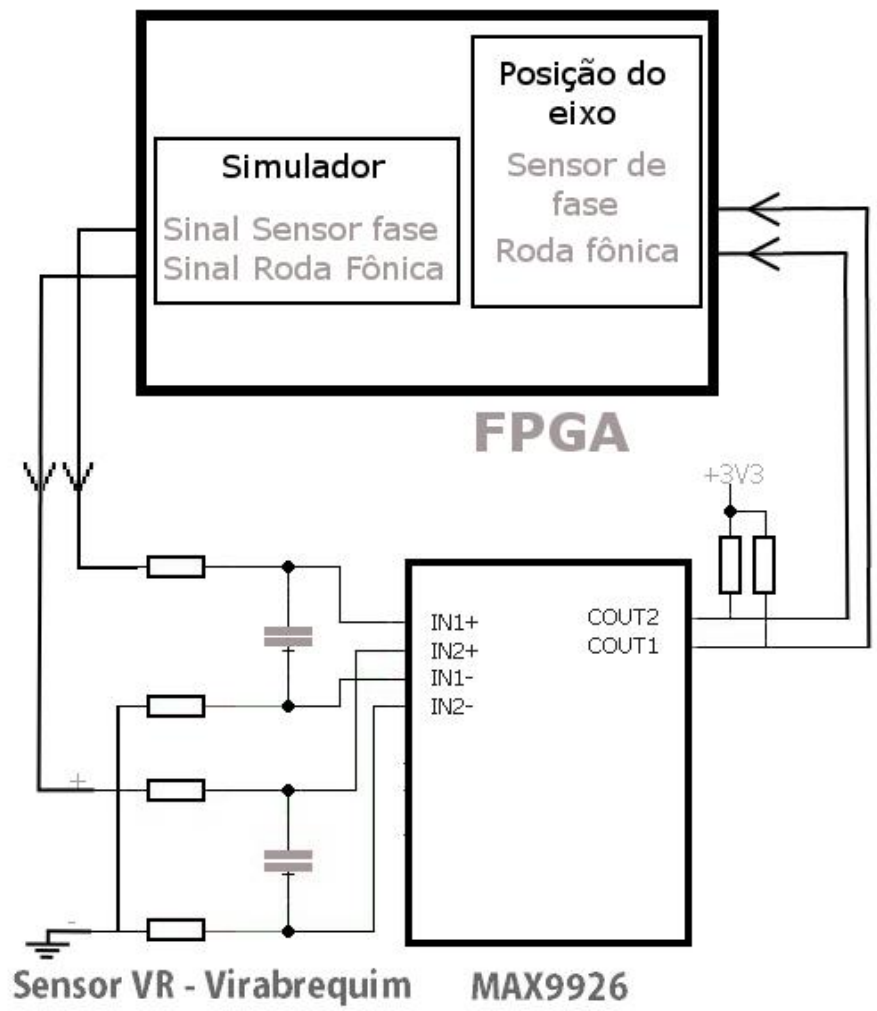

Figura 76 - Ensaio de código do sensor de posição do eixo do motor.

A primeira verificação realizada é referente à detecção dos dentes comuns e à validação das leituras dos períodos referentes a eles. Para isso, um sinal interno do núcleo que indica a validação do dente foi conectado a um pino de saída do FPGA, permitindo observar que sempre que ocorria um pulso do sinal do sensor de posição do eixo (figura 77 - sinal 
superior), um sinal correspondente era observado na saída de ensaio (figura 77 - sinal inferior). Uma exceção em dois dentes é observada, pois quando o circuito recebe o sinal referente à falha de dente da roda dentada o sinal não é validado, a validação só ocorre depois de realizadas as leituras de mais dois dentes comuns.

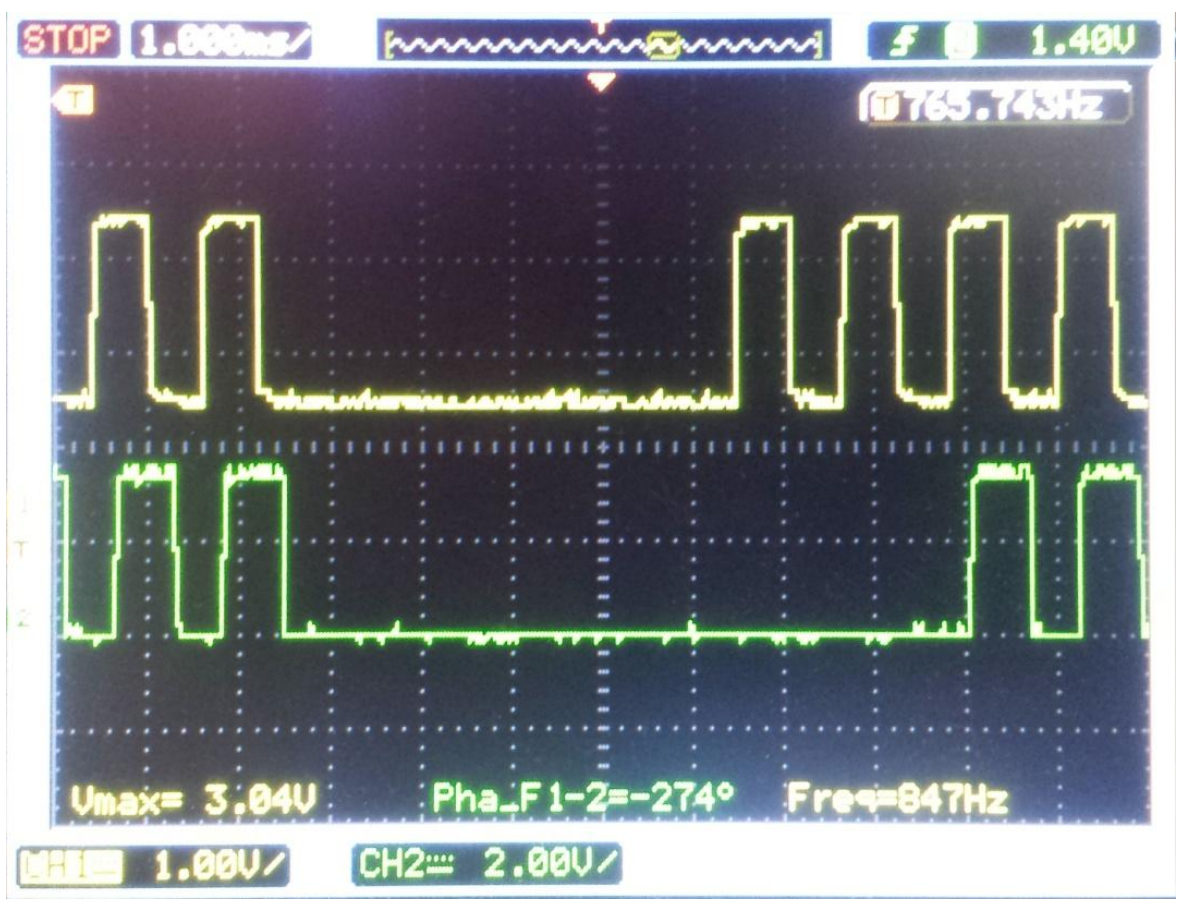

Figura 77 - Verificação da detecção dos dentes da roda fônica simulada.

A segunda verificação realizada no núcleo de estimação da posição do eixo foi a detecção da falha de dente da roda dentada. O mesmo procedimento adotado para observar a detecção dos dentes foi utilizado para verificar a detecção da falha de dente. Portanto, sempre que a falha é detectada, um pulso é gerado na saída utilizada para ensaios (figura 78). 


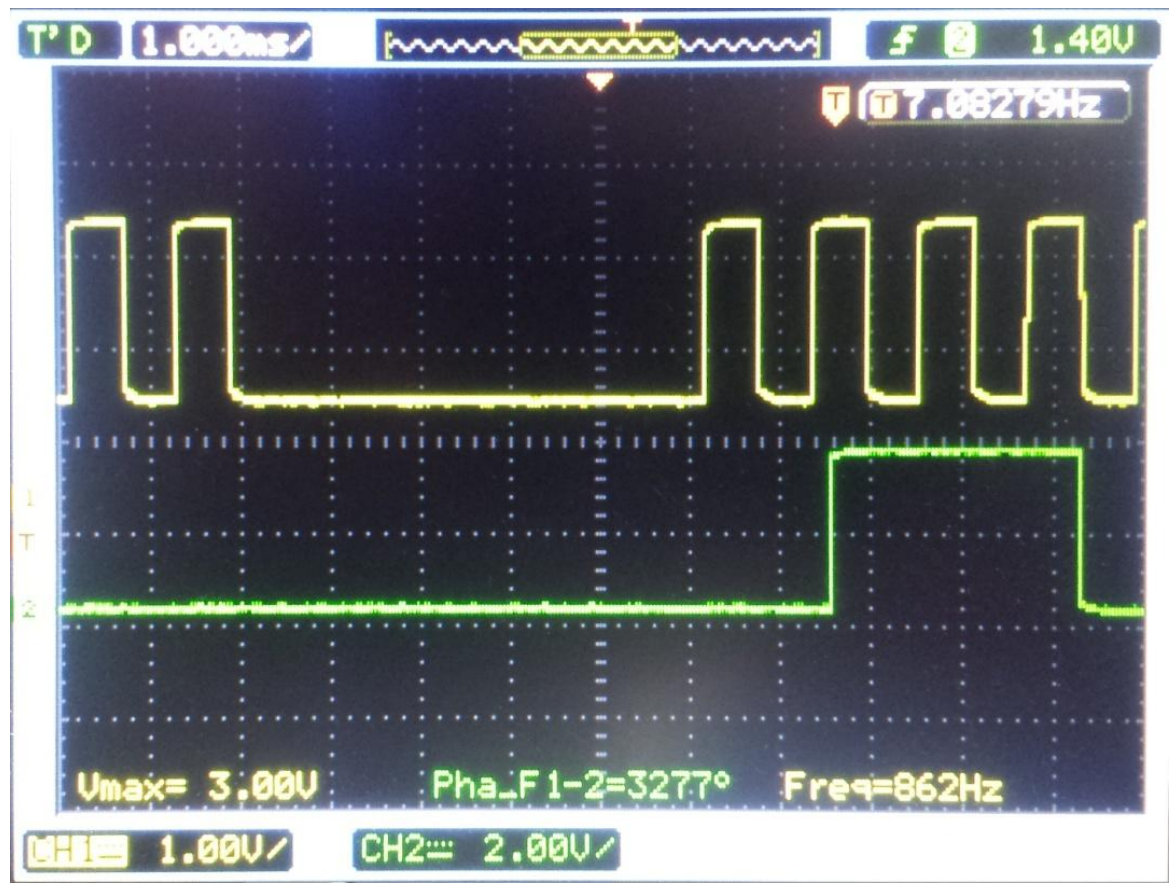

Figura 78 - Verificação da detecção da falha da roda dentada.

Com o circuito detectando corretamente os dentes e falhas da roda dentada, iniciaramse os ensaios da estimação da posição do eixo. Para essa verificação, se optou por criar um núcleo de ensaios com um vetor de posições do eixo nas quais uma saída de testes deveria ser ativada e desativada (figura 79).

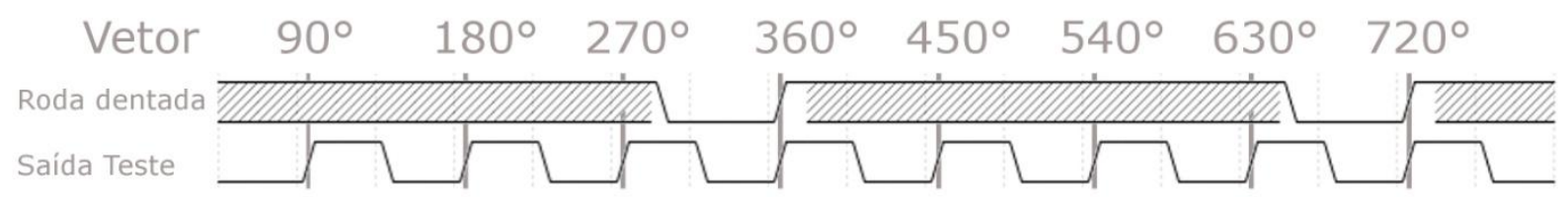

Figura 79 - Vetor com ângulos de comando.

O vetor foi criado com os valores das divisões de posição do eixo equivalentes aos ângulos de 0, 90, 180, 270, 360, 450, 540, 630 e 720 graus (valores de divisão iguais a 0, $8192,16384,24576,32768,40960,49152,57344$ e 65536). Sempre que o sinal que indica a posição atual do eixo tem o valor igual ao da tabela, um pulso de aproximadamente $2 \mathrm{~ms}$ é gerado na saída de ensaios (figura 80 e 81). 


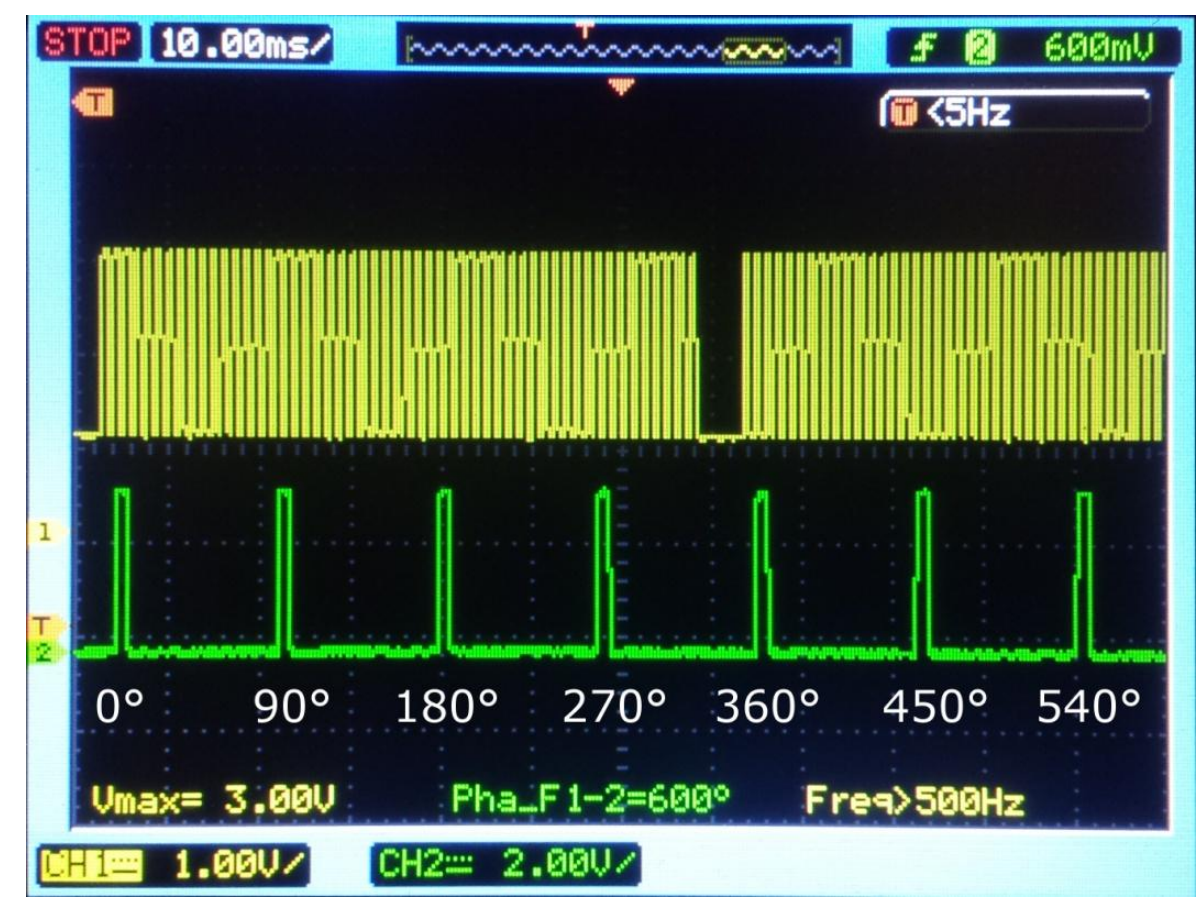

Figura 80 - Sinal de ensaio de estimação da posição do eixo (Detalhe).

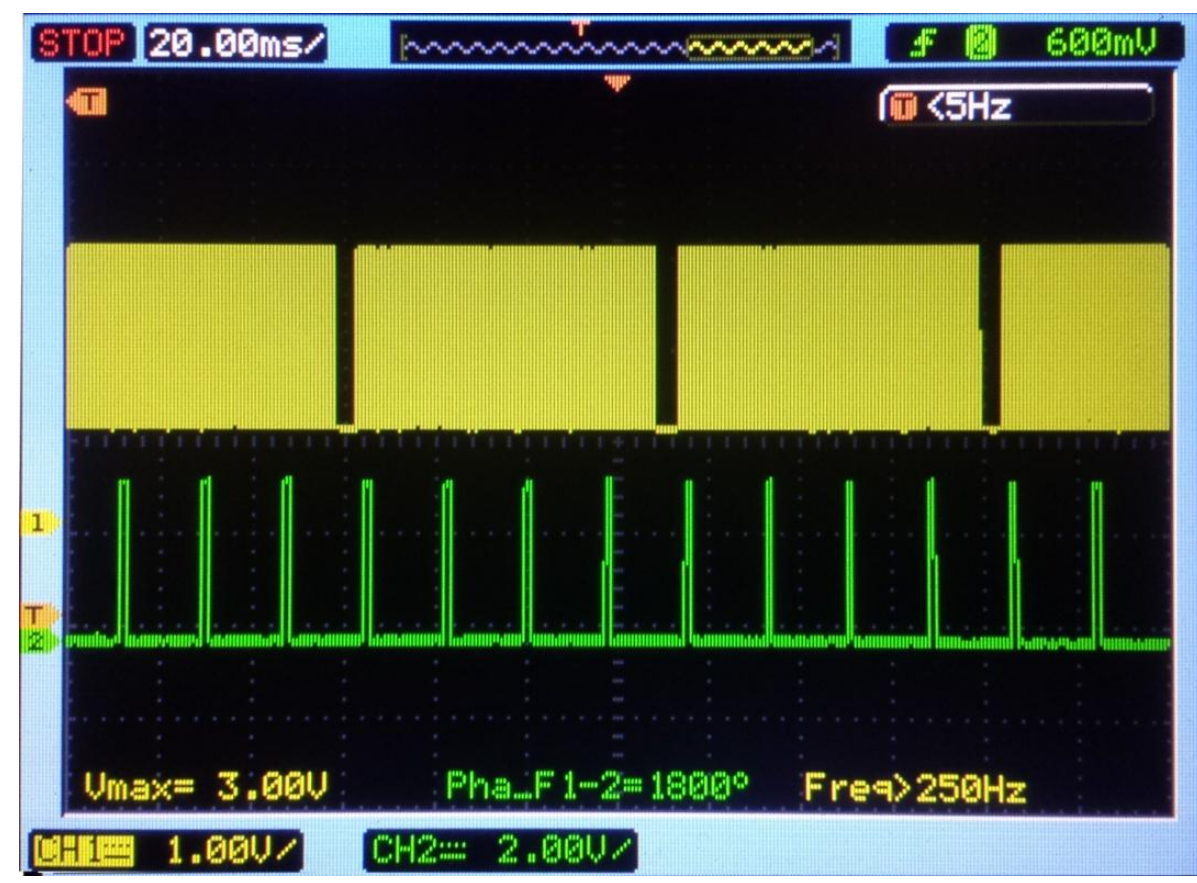

Figura 81 - Sinal de ensaio de estimação da posição do eixo (Estendido).

Por fim, para finalizar os ensaios básicos dos núcleos, foram realizados os ensaios de comando dos atuadores. Para isso, o núcleo de comando das bobinas foi conectado aos demais núcleos e os ângulos de 0, 90, 180, 270 e 360 graus foram utilizados para ensaios (figura 82). Nesse caso, as posições foram informadas manualmente com o auxilio da IHM e verificados um a um se a saída era comandada corretamente. 

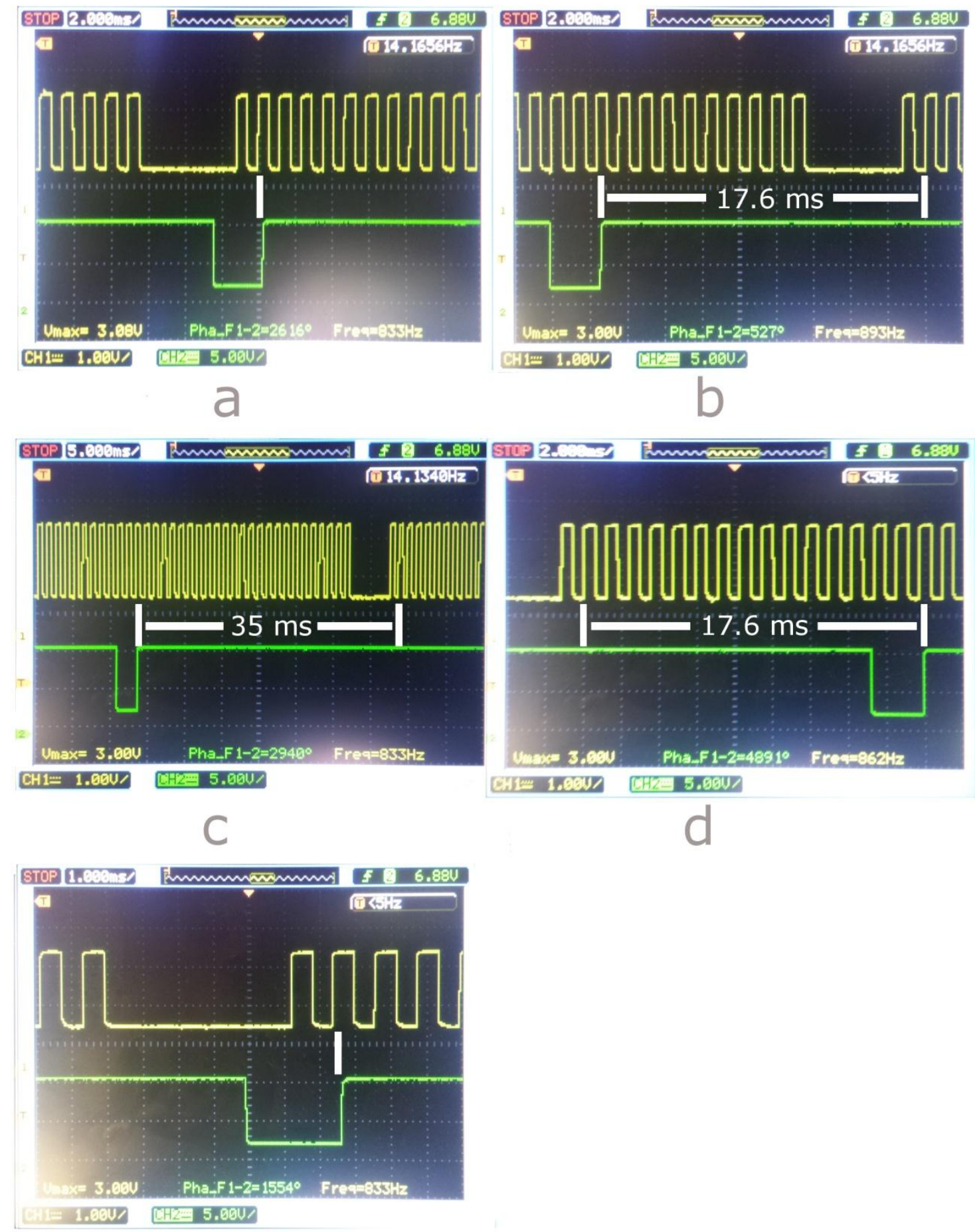

Figura 82 - Ensaios de acionamento com a roda dentada simulada a 850 RPM.

Com o sinal simulado a 850 RPM, o período máximo de um ciclo é aproximadamente de 70,59 ms. Para acionamentos equidistantes dos atuadores de 90 em 90 graus, este valor deve ser dividido por quatro para saber qual é a distância entre acionamentos, que é igual a 
17,65 ms. Na figura 78 é apresentado o momento de detecção da falha da roda dentada, este ponto é considerado como o ângulo de 0 ou 360 graus.

Como visto na figura 82.e, o final de acionamento do atuador ocorre exatamente no ponto onde é detectada a falha do sinal da roda dentada. Na figura 82 se observa o intervalo de 17,6 ms entre os acionamentos, o que condiz com o esperado. A precisão do acionamento foi medida considerando a diferença entre o sinal de detecção da falha e o final do comando do atuador. Como não foi possível verificar uma diferença com a análise utilizando o osciloscópio, foi considerado como erro mínimo o ângulo equivalente à menor divisão de escala ao redor do ponto verificado. A divisão mínima na escala de $1 \mathrm{~ms}$ do osciloscópio é de $0,2 \mathrm{~ms}$, o que equivale a aproximadamente 1 grau no ciclo do motor. Portanto, com a variação de sinal dentro dessa divisão, pode-se afirmar que o sistema tem ao menos a precisão de acionamento de 1 grau na velocidade de marcha lenta com o sinal simulado.

\subsection{Verificação em bancada}

A verificação em bancada foi realizada com o auxilio de um encoder com resolução de $3,33^{\circ}$ (108 janelas) conectado à entrada de sinal do sensor de posição do eixo (figura 83). O encoder foi comandado com um motor de corrente contínua controlado com o auxílio do núcleo de PWM do FPGA e com um controlador PID executado pelo microcontrolador.

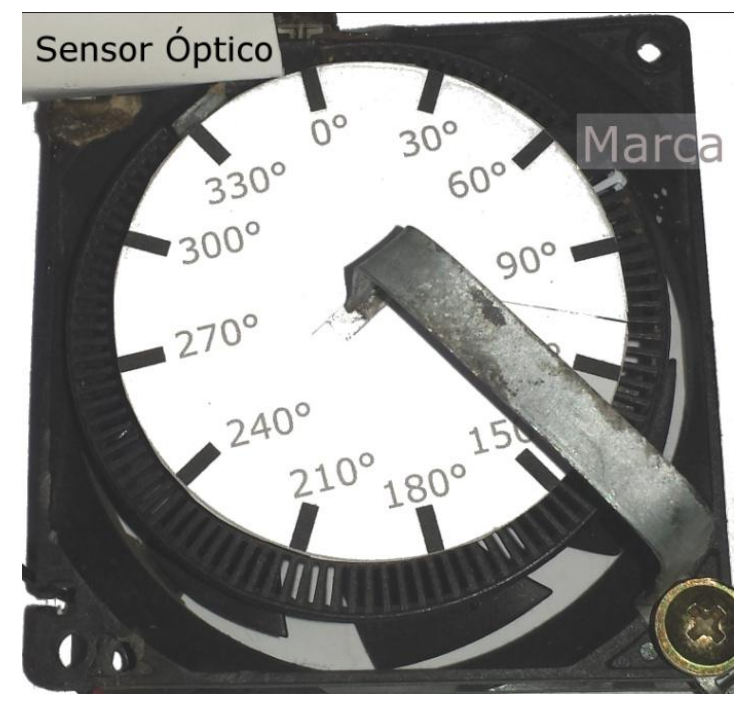

Figura 83 - Conjunto de encoder e motor. 
Nessa etapa de ensaios, o núcleo de estimação da posição do eixo foi modificado para operar sem o sensor de fase. Um sinal interno é carregado com nível lógico ' 1 ' quando ocorre uma falha no sinal do encoder e carregado com nível lógico ' 0 ' quando ocorre outra falha. A verificação foi realizada com um osciloscópio e com o auxílio de uma lâmpada led para verificação visual. A lâmpada led foi conectada a uma das saídas de potência de acionamento das bobinas. Dessa forma foi possível visualizar o acionamento de acordo com a posição do disco. A falha de dentes da roda dentada foi simulada com a obstrução de algumas janelas do disco do encoder (figura 84).

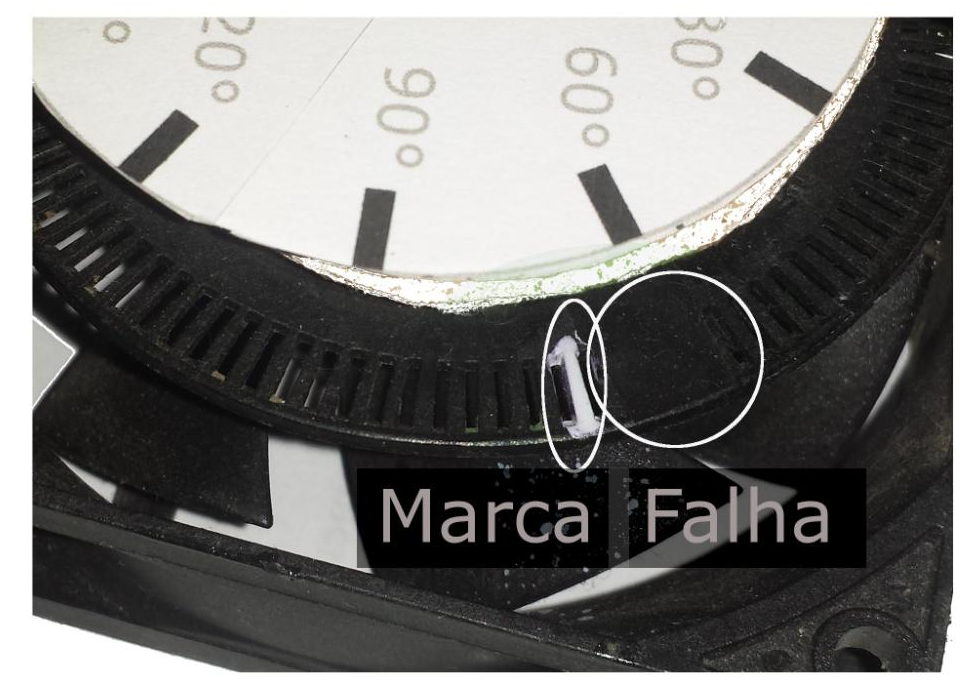

Figura 84 - Detalhes da marcação no disco do encoder e da falha de janelas.

O LED acende sempre que o atuador deve ser acionado e destaca a marca do disco. $\mathrm{Na}$ figura 85 observam-se as marcações para o disco girando a 850 RPM junto com as formas de onda medidas com o osciloscópio. O período de acionamento é de 2,7 ms ocorrendo a cada $90^{\circ}$. Foi necessário realizar um ensaio por ângulo, devido ao código de comando dos atuadores permitir um único comando por ciclo. $\mathrm{O}$ sinal senoidal foi medido diretamente na saída do encoder e, como visto anteriormente, passa pelo tratamento realizado pelo C.I. MAX9926, que quadra e inverte o sinal antes de ser ligado ao FPGA. 

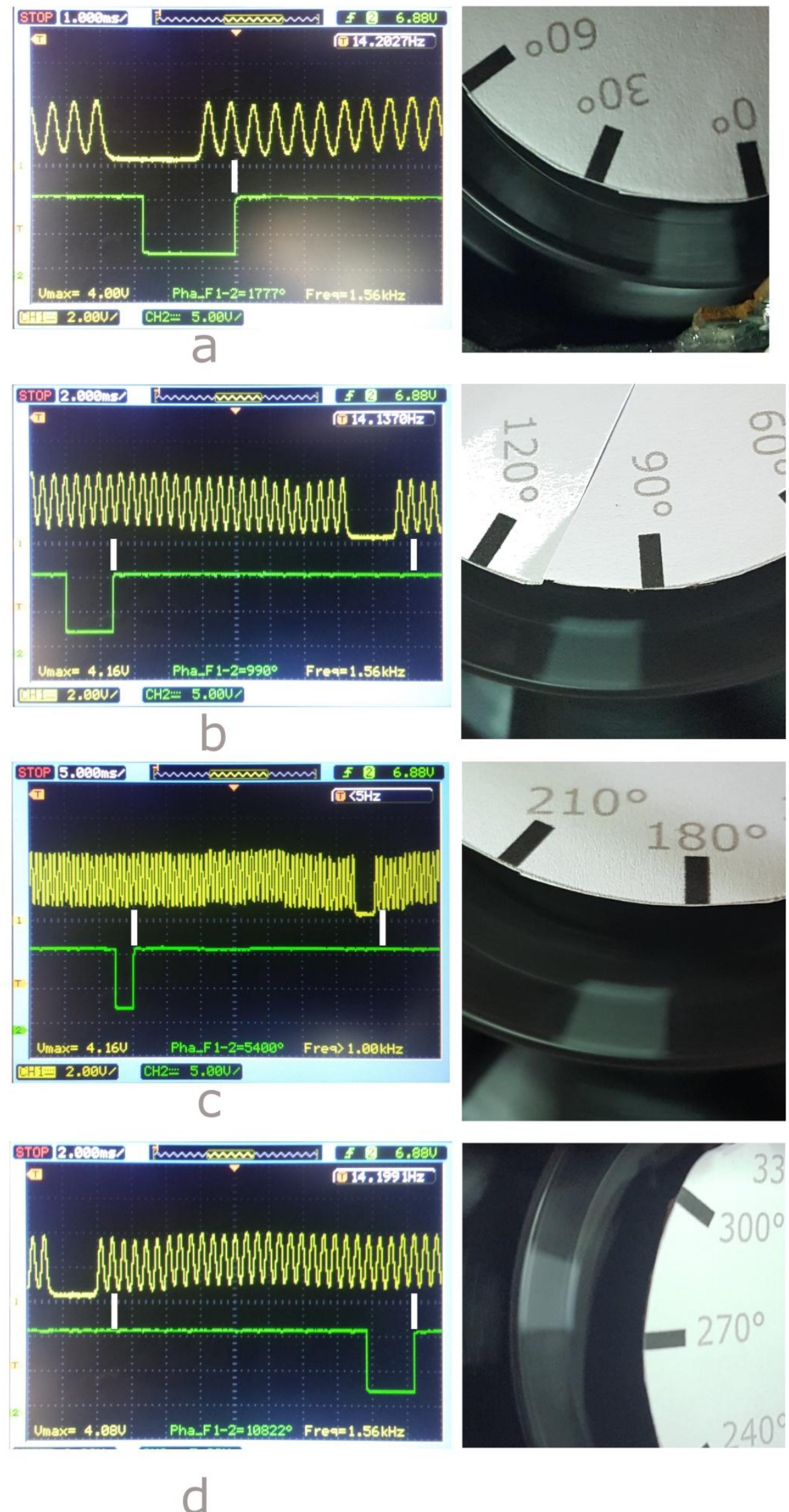

Figura 85 - Ensaios de ângulos de comando. 


\subsection{Ensaios na planta}

Os ensaios realizados na planta envolveram somente o comando das bobinas de ignição. Inicialmente, com o sistema operando originalmente, a lâmpada LED foi utilizada para ajuste inicial de ponto de ignição. Isso foi realizado com o motor em marcha lenta (850 RPM).

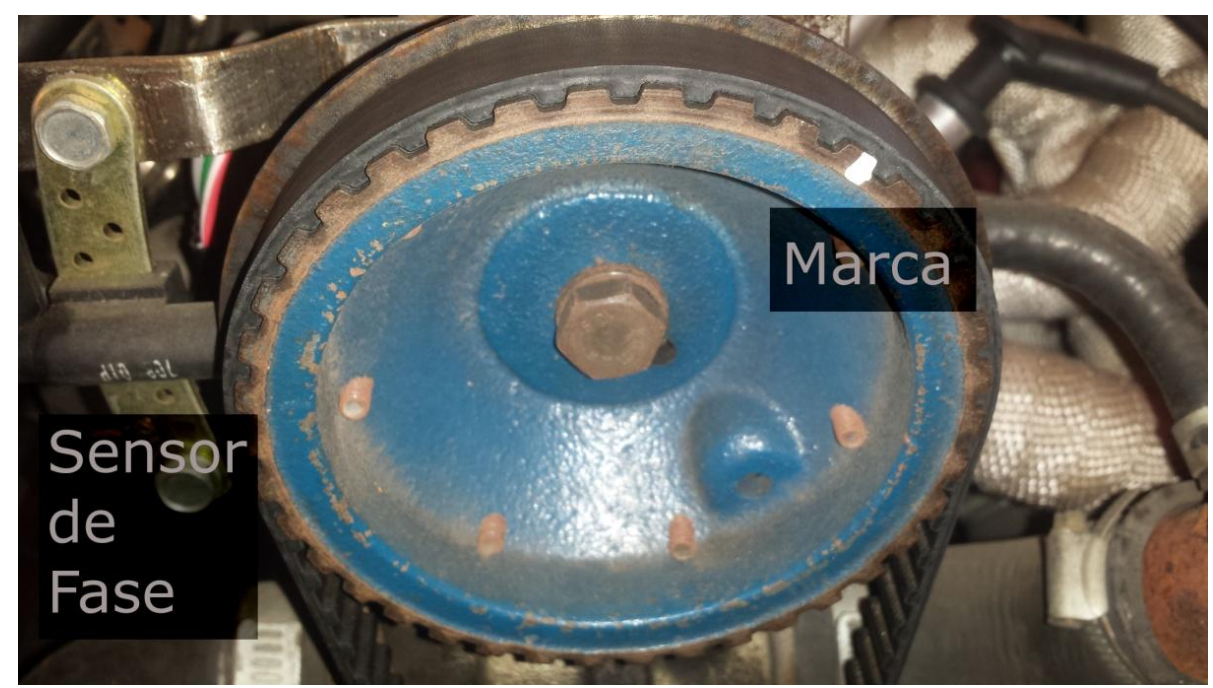

Figura 86 - Marca na polia do comando de válvulas.

Uma marca foi feita na polia do comando de válvulas e com o auxilio de um estroboscópio automotivo a posição em que ocorriam os pulsos de ignição do primeiro cilindro foi marcada (figuras 86 e 87). Essa posição foi considerada como parâmetro para ajuste do ponto de ignição do primeiro cilindro no protótipo. 


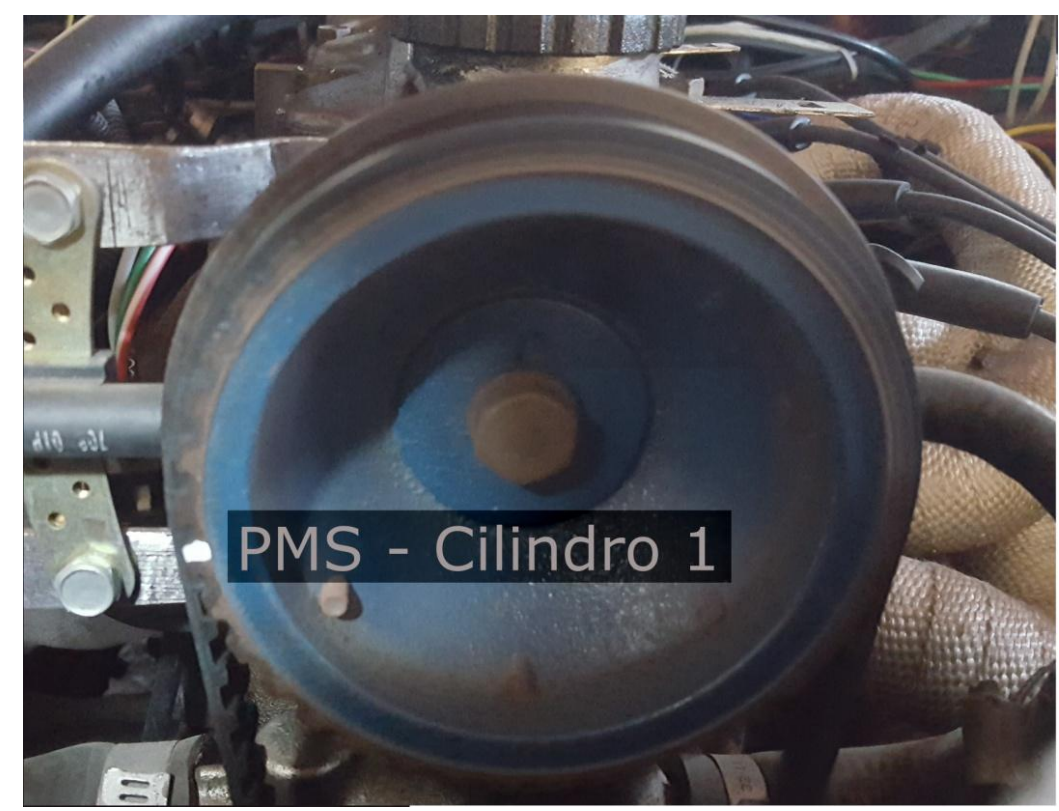

Figura 87 - Indicação do ponto onde ocorrem os pulsos de ignição do primeiro cilindro (850 RPM).

Antes dos ajustes de ponto serem realizados, a tabela de avanço de ponto de ignição foi ajustada para $10^{\circ} \mathrm{em}$ marcha lenta (850 RPM) devido a esse ser o ponto de ignição original para o sistema nesse regime (figura 88).

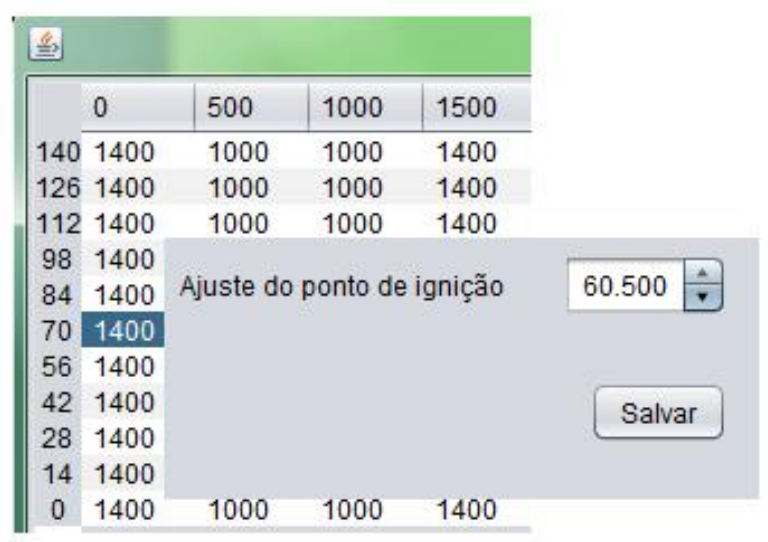

Figura 88 - Tabela de avanço de ponto de ignição e campo de compensação.

A compensação do ponto de ignição é realizada com a soma de um parâmetro de ajuste ao valor de ponto de ignição desejado. Esse parâmetro é necessário para que seja possível a compensação de erros de posicionamento do sensor (figura 88). Como visto na figura 89 a marca de comando do cilindro 1 está defasada da marca observada na figura 87. $\mathrm{O}$ que o parâmetro de ajuste faz é compensar essa defasagem, simulando o reposicionamento do sensor da roda dentada. 


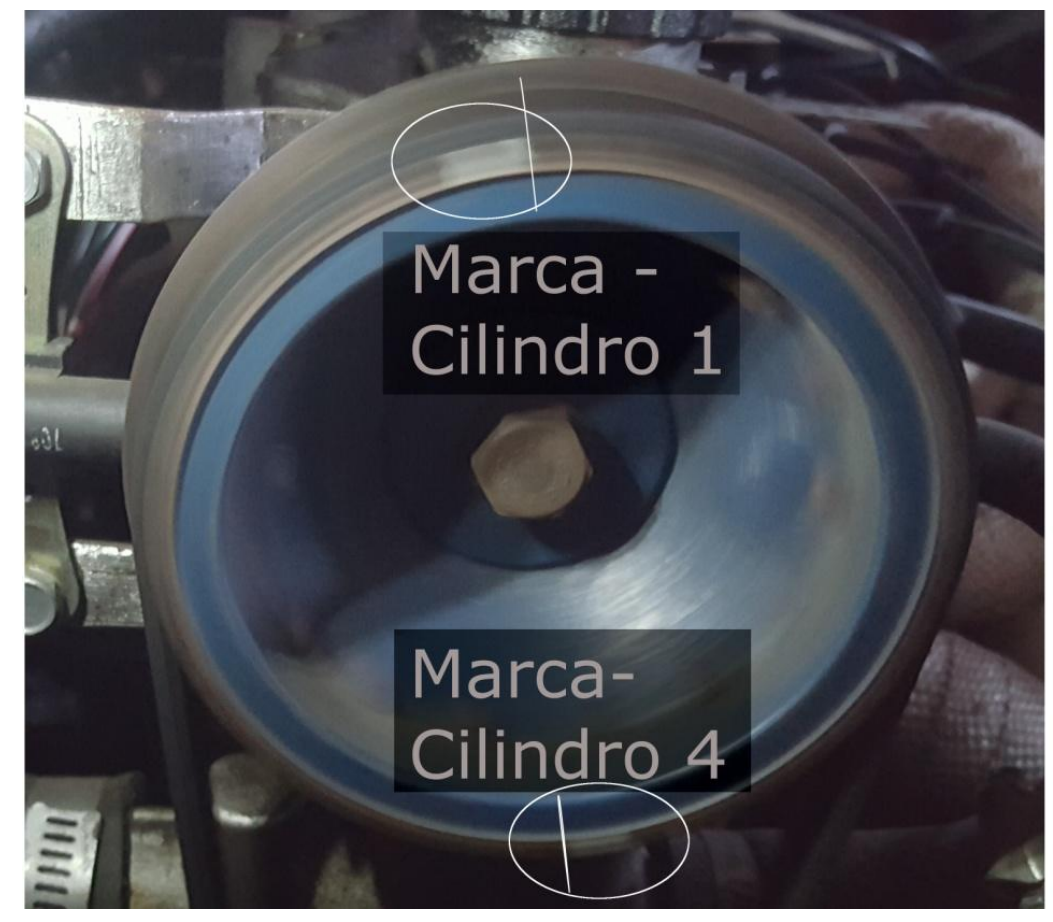

Figura 89 - Posição de acionamento sem o ajuste.

Depois de realizado o ajuste de ponto, o sistema original de ignição foi substituído pelo sistema experimental. São utilizadas duas bobinas de ignição, uma para cada dois cilindros (figura 90). O período de energização de $2,7 \mathrm{~ms}$ foi medido em um veículo (Chevrolet S10) que utiliza a mesma bobina aplicada no sistema experimental.

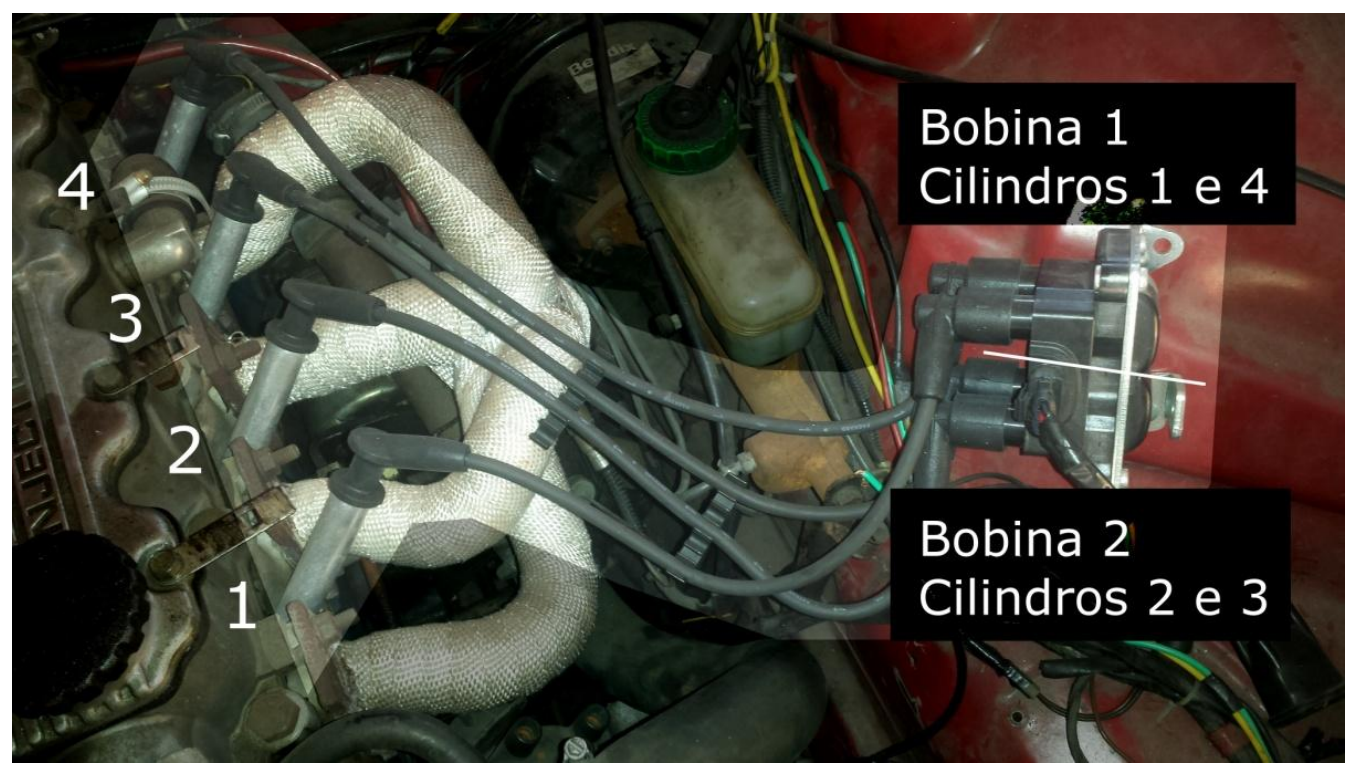

Figura 90 - Sistema de ignição experimental. 
Com o motor em marcha lenta, foram realizados ensaios similares aos feitos com o encoder na bancada. Verificou-se se as detecções dos dentes estavam ocorrendo em intervalos corretos e se a falha de dentes da roda dentada estava sendo identificada. Os sinais que indicam a detecção dos dentes normais e a detecção da falha da roda dentada podem ser verificados nas figuras 91 e 92. Como referência, é utilizado o sinal já condicionado do sensor de posição do eixo virabrequim (figura 91 e 92 - Sinal Superior).

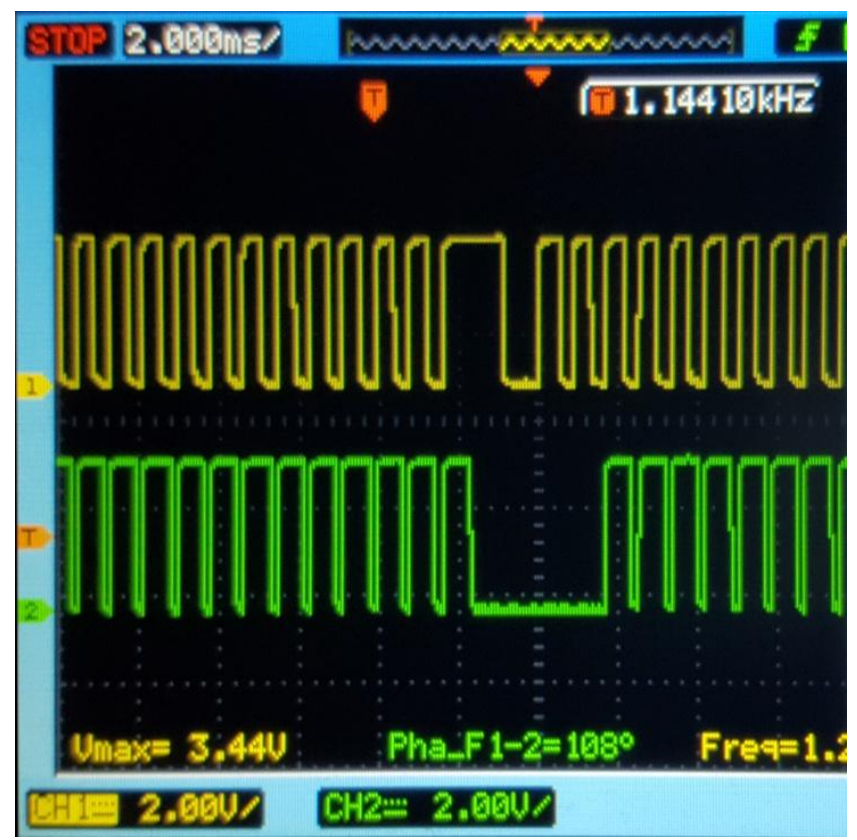

Figura 91 - Verificação da detecção e da validação dos períodos dos dentes.

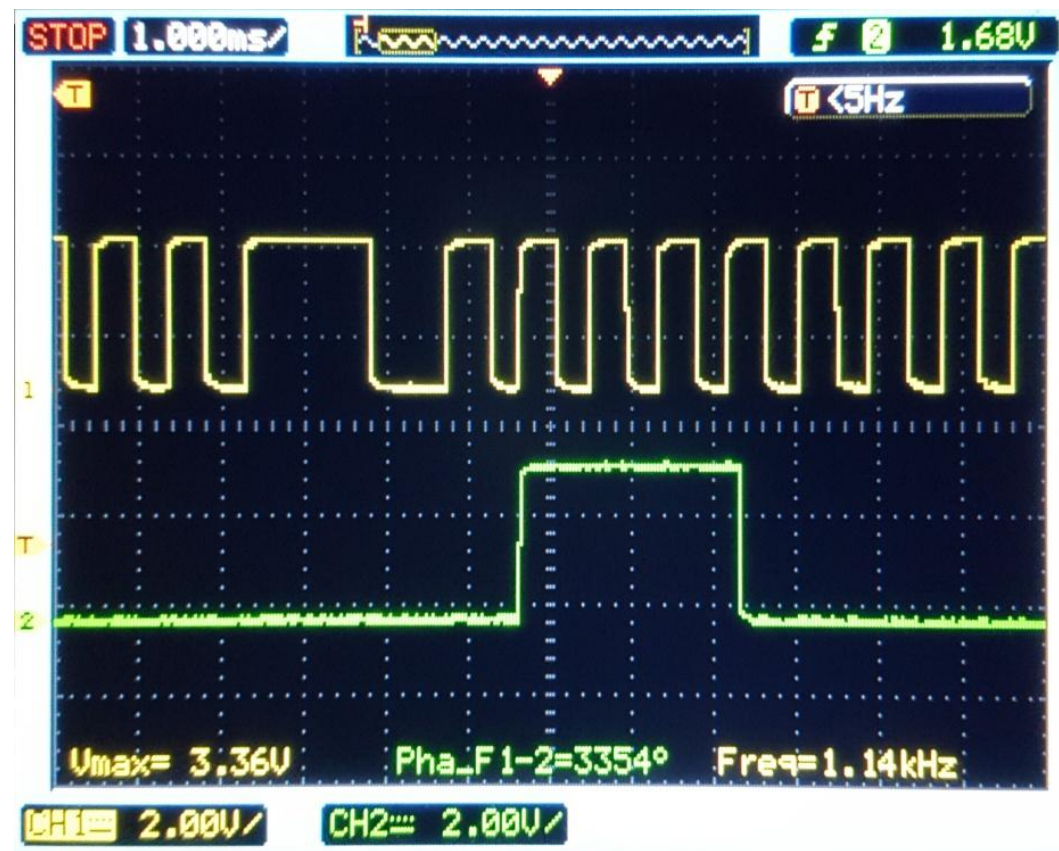

Figura 92 - Verificação da detecção da falha de dente. 


\section{$8 \quad$ Planta utilizada}

A planta utilizada para ensaios (figura 93) é um motor General Motors de 1,6 litros, 4 cilindros e com 2 válvulas por cilindro. O motor opera com injeção eletrônica multiponto.

Suas principais características, antes de iniciado este trabalho, podem ser observadas na tabela 4.

Tabela 4 - Características da planta utilizada

\begin{tabular}{ll}
\hline Fabricante & General Motors \\
Comando de Válvulas & Comando no cabeçote sincronizado por correia \\
& dentada \\
& 2 válvulas por cilindro \\
Válvulas & Presente, mas desativado \\
EGR & Etanol hidratado \\
Combustível & $75,7 \mathrm{~mm}$ \\
Curso & $82 \mathrm{~mm}$ \\
Diâmetro do pistão & 1600 centímetros cúbicos \\
Capacidade volumétrica & Multiponto com pressão da linha de combustível \\
Injeção & de 3 bar e bicos com vazão igual a 191,8 cc/min \\
& Uma bobina operando com distribuidor e avanço \\
Ignição & centrífugo e a vácuo.
\end{tabular}

Fonte: Mahle, 2004. 


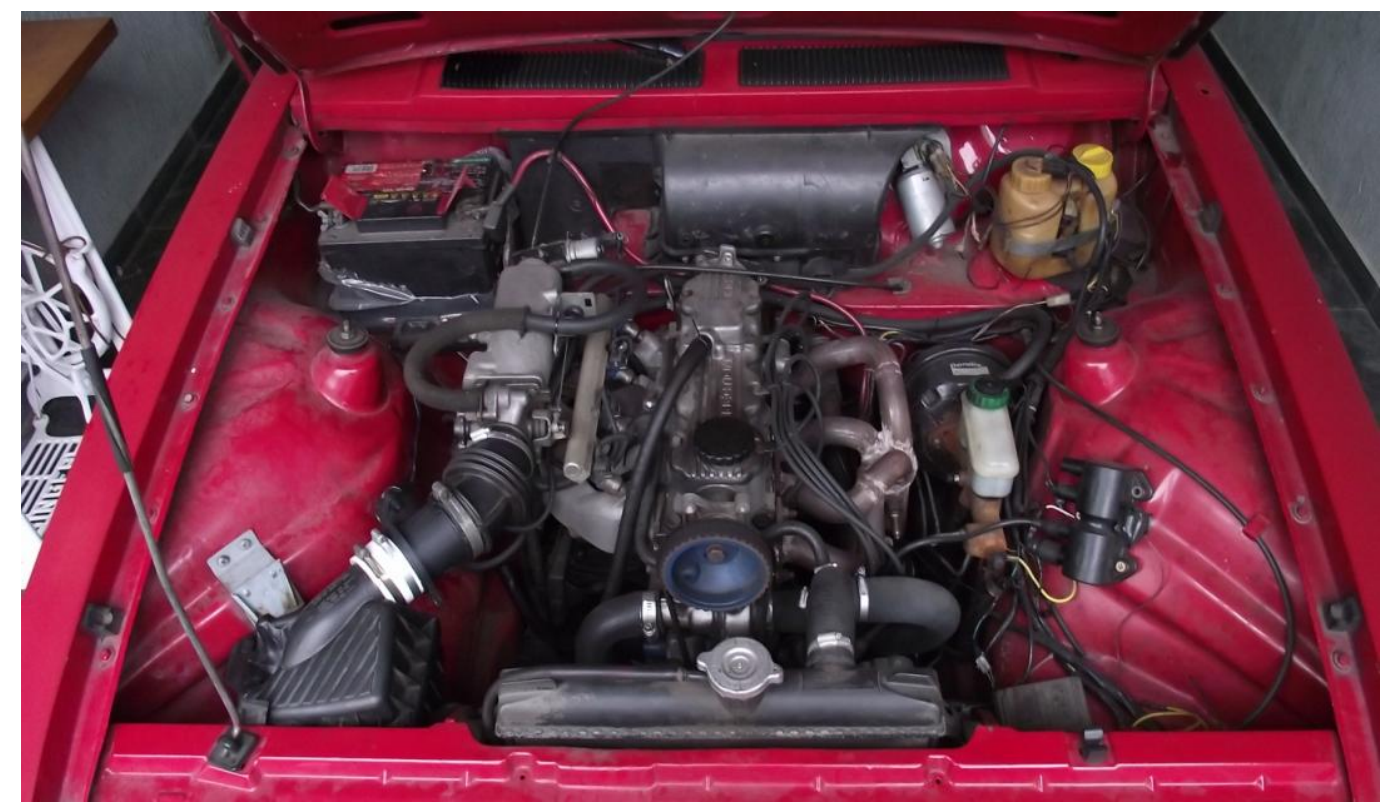

Figura 93 - Planta utilizada nos ensaios. 


\section{Conclusões e Sugestões para trabalhos futuros}

O trabalho atual visa ao desenvolvimento de um conjunto de software, firmware e hardware de um sistema base para aplicação de técnicas de controle em motores de combustão interna. Como forma de iniciar o desenvolvimento, foram criadas diversas características desejadas do sistema, como visto no capítulo 6 do trabalho. As exigências 1 e 2 indicavam a necessidade de o sistema permitir a alteração em tempo real da quantidade de combustível injetada e do avanço do ponto de ignição. Essas exigências foram cumpridas como o uso de tabelas de eficiência volumétrica e de ponto de ignição, que têm seus valores em função da velocidade do motor e da pressão dentro do coletor de admissão.

Considerando um motor de quatro cilindros, a exigência 3 foi cumprida com o uso de quatro saídas de comando de bicos injetores e levando em conta que todo o código testado para comando do sistema de ignição é o mesmo utilizado para comando do sistema de injeção de combustível. Nos capítulos de ensaios, são apresentadas as medições de comandos das saídas de ignição em diversos ângulos preestabelecidos. As escolhas dos ângulos de injeção e ignição podem ser feitas de forma independente, sendo que a precisão de acionamento permanece dentro do limite de 1 grau (exigências 4 e 5), como explanado durante a análise dos sinais obtidos durante os ensaios utilizando o simulador da roda dentada (capítulo 7.2). A análise foi realizada com os sinais simulados na velocidade de 850 RPM. Devido à velocidade de execução e resolução dos contadores do código, considerou-se que essa precisão seria próxima com o sistema operando na planta real e em outros regimes de operação.

A facilidade de alterações de código (item 6) existe primeiramente devido ao código do microcontrolador ser todo desenvolvido na IDE da placa Arduino. A grande quantidade de material disponibilizado pela comunidade de usuários desse sistema torna mais fácil o desenvolvimento e ampliação das funcionalidades utilizando essa plataforma. Sobre a parte do sistema que utiliza o FPGA (TPU), observa-se que a IDE da Xilinx também é de livre acesso e a ampliação de funcionalidades, como adicionar novos bicos injetores ou bobinas de ignição, não é uma tarefa difícil considerando as características de processamento paralelo e modularidade do código que permite simples inserção de um núcleo de comando para que outro atuador possa ser utilizado.

Um sistema comercial de controle de um motor de combustão interna geralmente utiliza os sensores MAT, IAT, CLT, MAF, MAP, TPS e O2 (até dois), o que totaliza três sensores resistivos e cinco sensores com saídas de tensão variável. Dessa maneira, o sistema 
desenvolvido nesse trabalho apresenta mais uma entrada livre (total de quatro) para medição de sensores resistivos e mais três entradas analógicas livres (total de oito) para outros sensores, que também podem ser adaptadas para leitura de sensores resistivos. Considerando os sensores citados, a exigência de número 7 foi cumprida, no entanto, sistemas modernos utilizam uma quantidade maior de sensores que podem vir a esgotar a quantidade de entradas A/D disponíveis. O estudo da detecção do efeito de detonação não foi considerado nesse trabalho devido a sua complexidade, como apresentado por Filardi (2013). Esta análise fica como sugestão para um futuro trabalho, que pode, caso o microcontrolador tenha capacidade de processamento, utilizar um circuito de tratamento de sinais em conjunto com uma entrada analógica, ou utilizar a porta de comunicação CAN para comunicação com um módulo dedicado a essa função, como proposto por Pujatti 2007.

$\mathrm{Na}$ segunda placa protótipo, foram disponibilizadas quatro saídas para comando de bicos injetores, quatro saídas para comando de bobinas de ignição (exigência 11), quatro saídas de comando de cargas indutivas (atuador de marcha lenta) e mais sete saídas auxiliares, totalizando 19 saídas, o que não cumpre com a exigência 8, de 24 saídas. No entanto, tanto o microcontrolador quanto o FPGA apresentam uma quantidade muito superior a 24 saídas disponíveis para serem utilizadas em projetos futuros, portanto isso não é considerado como uma limitação.

Na exigência 9, foi considerado como um valor mínimo de taxa de aquisição de dados a velocidade de dez vezes o valor de frequência máxima de rotação do motor (considerado 15000 RPM), o que foi cumprido levando em conta que é possível realizar até 333 leituras por ciclo do motor a 15000 RPM. No entanto, essa taxa de aquisição não pode ser garantida devido ao peso computacional das estratégias de controle influenciar na velocidade com que as entradas analógicas são acessadas pelo microcontrolador. Da mesma forma, como já comentado, o controle de próximo ciclo pode ou não ser possível de acordo com a estratégia de controle adotada (exigência 10).

Apesar de a TPU ser responsável pela temporização de acionamentos de atuadores e pelo sincronismo deles, vê-se a necessidade de um nível mínimo de sincronismo do microcontrolador com a posição do eixo do motor. Isso se deve a alguns algoritmos de controle executarem o tratamento dos sinais de acordo com a posição do eixo do motor. Para executar algoritmos sincronizados com a posição do eixo do motor, considera-se em trabalhos futuros a criação de um sinal de sincronismo que é enviado pela TPU ao microcontrolador a cada $\theta$ graus, sendo que $\theta$ é definido pela equação 9 . 


$$
\theta=\frac{\theta_{\text {total }}}{N_{\text {cilindros }}}
$$

$\theta=$ Ângulo de defasagem entre ciclos.

$\theta_{\text {total }}=$ Variação total de ângulo do eixo do motor por ciclo de funcionamento. Igual a 720 graus para ciclos 4 tempos e 360 graus para ciclos dois tempos.

$N_{\text {cilindros }}=$ Número de cilindros do motor.

Este sinal de sincronismo deve ser enviado pela porta SPI enquanto o controlador está enviando os dados de comando dos atuadores à TPU. Essa aproximação de sincronismo é uma das características necessárias para cumprir com o item 10 de exigências preestabelecidas.

A exigência de número 12 foi cumprida, utilizando-se dois circuitos integrados MAX9926, o que totaliza quatro entradas para sensores de relutância variável, permitindo a aplicação de mais sensores de posição do eixo ou de velocidade da carroceria.

A IHM foi desenvolvida em JAVA e permite a configuração das tabelas de eficiência volumétrica e de avanço de ponto de ignição. Os valores de ganhos do controlador PID, executado para controle do motor nos experimentos em bancada, também podem ser configurados. Outra função da IHM é apresentar os valores lidos das entradas analógicas do microcontrolador com uma taxa de atualização de $10 \mathrm{~Hz}$ e fazer o datalog desses dados. Uma sugestão para trabalhos futuros é ampliar o suporte a configurações do controlador, como gravação dos ângulos de acionamento dos bicos injetores e os períodos de acionamento das bobinas de ignição. Esses valores atualmente são colocados como constantes no código do microcontrolador. Como forma de manter os dados salvos no microcontrolador, foi adicionada ao circuito uma memória EEPROM (24lc256) que recebe todos esses dados enviados pela IHM (exigência 14).

Durante o desenvolvimento dos ensaios, observou-se que o uso de um estroboscópio feito com uma lâmpada LED poderia ser realizado utilizando uma das saídas de potência livres do circuito, portanto a exigência número 15 não foi considerada como um problema, devido à facilidade de reconfiguração do circuito e utilização de outras saídas para essa função. A exigência de embutir um sensor MAP dentro do chassis do controlador não foi considerada, por se tratar de uma simples questão física de fixação do sensor, que até o momento não foi utilizado em ensaios. O sensor a ser utilizado no sistema, como comentado 
anteriormente, cumpre com a exigência de um valor de pressão máxima de $200 \mathrm{kPa}$ e pode utilizar uma das entradas analógicas comuns do microcontrolador.

Por fim, como uma das características principais do sistema, foi colocado que tanto software quanto hardware deveriam ser de livre acesso e de fácil obtenção. Uma exceção a essa regra foi a utilização da linguagem LabView para programação do software que carrega o arquivo de configuração do FPGA na memória Flash dedicada a essa função. Em trabalhos futuros propõe-se que essa função seja integrada à IHM desenvolvida em JAVA.

Assim sendo, apesar do desenvolvimento do sistema não ter seguido a risca as exigências iniciais, tais exigências serviram como um bom guia ao desenvolvimento do trabalho. 


\section{Referências}

Albaladejo, F. S. Desenvolvimento de uma Unidade de Gerenciamento Eletrônico para Motores de Combustão Interna do Ciclo Otto. Dissertação (Mestrado em Engenharia) Programa de Pós-Graduação em Microeletrônica da Escola Politécnica da Universidade de São Paulo, São Paulo, 2013.

Andersson, Ingemar. Cylinder Pressure and Ionization Current Modeling for Spark Ignited Engines. 2002. 93 f. Thesis No. 962, Division of Vehicular Systems, Department of Electrical Engineering, Linköping Universitet, Linköping, 2002.

ANDO, R.; KOIZUMI, M.; ISHIKAWA, T. Development of a Simulation Method for Dynamic Characteristics of Fuel Injector. IEEE Transactions on magnetic, Vol. 37, 2001.

ASHOK, B; ASHOK S.D.; RAMESH KUMAR C. A review on control system architecture of a SI engine management system. Annual Reviews in Control, 2016.

Bosch Microelectronics. Datasheet - BIP373. Datasheet. Disponível em:< http://www.megamanual.com/ms2/bip373_datasheet.pdf>. Acesso em: 18 jan 2016.

Bosch Motorsports. Gasoline Engine Control Units. Disponível em: $<$ http://www.boschmotorsport.de/en/de/produkte/catalog_categories_sncd_lev_1_735297.php>. Acesso em: 26 jul 2016.

Bosch. Hot-film air-mass meter, type HFM5. Datasheet. Disponível em: <http://rbaa.bosch.com/boaasocs/modulespdf/Bosch_AA_Sensoren_PDFGen.dll?db=BOAAMDB02PRD7\&MV_ID=963\&CL_ID=20 $\&$ Prod_ID $=341 \&$ filename $=0281002421 . p d f>$. Acesso em: 19 mar 2015.

Bosch. Inductive speed sensor with and without cable. Datasheet. Disponível em: $<$ http://rb-aa.bosch.com/boaasocs/modulespdf/Bosch_AA_Sensoren_PDFGen.dll?db=BOAAMDB02PRD7\&MV_ID=963\&CL_ID=20 $\&$ Prod_ID=156\&filename=0261210104.pdf $>$. Acesso em: 12 ago 2015 .

Bosch. Knock Sensor. Bosch Motorsport, 2016.

Bosch. Lambda Sensor LSU 4.9. Bosch Motorsport. 2011. 
Bosch. NTC temperature sensors: $-40^{\circ} \mathrm{C}$ to $130^{\circ} \mathrm{C}$ - Measurement of air temperatures. Datasheet. Disponível em: <http://rb-aa.bosch.com/boaasocs/modulespdf/Bosch_AA_Sensoren_PDFGen.dll?db=BOAAMDB02PRD7\&MV_ID=963\&CL_ID=20 $\&$ Prod_ID=319\&filename=0280130039.pdf $>$. Acesso em: 19 mar 2015.

Bosch. Throttle valve angle sensor - Measurement of angles up to $86^{\circ}$. Datasheet. Disponível em: < http://rb-aa.bosch.com/boaasocs/modulespdf/Bosch_AA_Sensoren_PDFGen.dll?db=BOAAMDB02PRD7\&MV_ID=963\&CL_ID=20 $\&$ Prod_ID=808\&filename=0280122024.pdf > . Acesso em: 11 abril 2016.

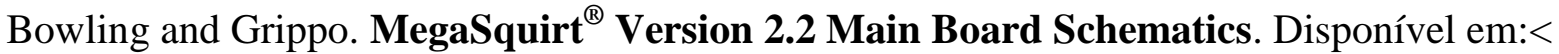
http://www.bgsoflex.com/v22/megasquirt_ShemV2.2.pdf>. Acesso em: 25 ago 2014.

BRUNETTI, F. Motores de Combustão Interna - Volume 1, Blucher, 2012.

CAMPOS, M.; REIS FILHO, C.A. Knock Sensor Signal Conditioner. Proceedings of the Fifth IEEE International Caracas Conference on Devices, Circuits and Systems, Republica Dominicana, Novembro, 2004.

DELPHI. Delphi Electronic Throttle Controls and Mechanical Throttle Bodies. Disponível em: < http://delphi.com/manufacturers/auto/powertrain/gas/aircontrol/etc_mtc >. Acesso em: 12 março 2016.

Drivven - National Instruments. NI Powertrain Control Modules for NI CompactRio. Disponível em:< http://sine.ni.com/nips/cds/view/p/lang/pt/nid/210060>. Acesso em:26 jul 2016.

Fairchild. NA-8208 - Introduction to Automotive Ignition Systems. Fairchild Semiconductor Corporation, 2014.

Filardi, J. B. C. Caracterização de Detonação de um Motor de Combustão Interna com Ondas Mecânicas. Tese (Doutorado em Engenharia) - Programa de Pós-Graduação em Engenharia Mecânica da Universidade Federal de Minas Gerais, Belo Horizonte, 2013.

FLEMING, W. J. Overview of Automotive Sensors. IEEE Sensors Journal, Vol. 1, No. 4, Dezembro de 2001.

FRADEN, J. Handbook of Modern Sensors - Physics, Designs, and Applications, Springer, 2010. 
Guedes, M.A.C. Estudo de compensadores para a válvula borboleta eletrônica automotiva. 2014. 155 f. Dissertação (Mestrado em Ciências) - Escola Politécnica da Universidade de São Paulo, Engenharia Elétrica - Sistemas Eletrônicos, São Paulo, 2014.

GUZZELLA, L; ONDER, C.H. Introduction to Modeling and Control of Internal Combustion Engine Systems. Second edition. Springer 2010.

Hendricks, E.; Luther, J. B. Model and Observer Based Control of Internal Combustion Engines. Proceedings of the $1^{\text {st }}$ Workshop on Modeling Emissions and Control in Automotive Engines (MECA), 9-20 Setembro, Fisciano, pp. 1-12, 2001.

Hendricks, E.; Sorenson, S. Mean Value SI Engine Model for Control Studies. American Control Conference, 1990.

HEYWOOD, J. B. Internal Combustion Engine Fundamentals. McGraw-Hill, 1988.

HU CHUN-MING; JU BING. Nonlinear Parameters Identification of Mean Value Engine Models Based on Neural Network. 2011 International Conference on Transportation, Mechanical, and Electrical Engineering (TMEE). Changchun, China, 2011.

KLEIN, M.; ERIKSSON, L. A specific Heat Ratio Model for Single-Zone Heat Release Models. SAE, 2004.

Magnusson, Janek. An Investigation of Maximum Brake Torque Timing based on Ionization Current Feedback. 2007. 61 f. Master's thesis in Vehicular Systems - Department of Electrical Engineering at Linköping University, Linköping, 2007.

MAHLE. Informações Técnicas. 2004.

MALACZYNSKI, G. W. et al. Replacing Volumetric Efficiency Calibration Look-up Tables with Artificial Neural Network-based Algorithm for Variable Valve Actuation. SAE International. 2010.

Maxim Integrated Products. Variable Reluctance Sensor Interfaces with Differential Input and Adaptive Peak Threshold. Sunnyvale, 2012. 
Milhor, C. E. Sistema de Desenvolvimento para Controle Eletrônico dos Motores de Combustão Interna Ciclo Otto. Dissertação (Mestrado em Engenharia Mecânica). Escola de Engenharia de São Carlos da Universidade de São Paulo. São Carlos, 2002.

MOHSIN, M. H. et al. An efficient carburetor design using electronic fuel injection for small vehicles based on 110cc self start 4 stroke engine. Multi-Topic Conference (INMIC), IEEE 17th Internacional, 2014.

ZAVALA, J. C.; STEWART, P.; FLEMING, P. J. Multiobjective Automotive Drive by Wire Controller Design. IEEE International Symposium on Computer Aided Control System Design Proceedings, Glasgow, Scotland, U.K., 2002.

NIELSEN, L.; KIENCKE, U. Automotive Control Systems - For Engine, Driveline, and Vehicle. Second edition. Springer, 2005.

NING CHEN; YUN ZHANG. Analysis of Ignition Energy Efficiency for Automotive Ignition Coils. Asia-Pacific Power and Energy Engineering Conference, 2010.

Pujatti, F. J. P. Desenvolvimento de um Sistema de Gerenciamento Eletrônico para Motores de Ignição por Centelha. Tese (Doutorado em Engenharia) - Programa de Pós-Graduação em Engenharia Mecânica da Universidade Federal de Minas Gerais, Minas Gerais, 2007.

SCHÄFER, F; BASSHUYSEN, R. Reduced Emissions and Fuel Consumption in Automobile Engines. Springer, 1995.

Souza de Andrade, G. Avaliação Experimental da Duração de Combustão para Diferentes Combustíveis, em um Motor Padrão Ciclo OTTO ASTM-CFR. Dissertação (Mestrado em Engenharia) - Programa de Pós-Graduação em Engenharia Mecânica da Escola de Engenharia da Universidade Federal do Rio Grande do Sul, Porto Alegre, 2007.

Texas Instruments. LM1949 Injector Drive Controller. Texas Instruments Incorporated, Texas, 2015.

Xess Corporation. XuLA2.Disponível em: $<$ https://github.com/xesscorp/XuLA2 >. Acesso em: 15 julho 2015 .

Xilinx. Spartan-6 FPGA Configuration User Guide - UG380 (v2.8), 2015.

Xilinx. Spartan-6 FPGA Packaging and Pinouts - UG385 (v2.3), 2014. 
YI-HU WU; HUANCHUN GONG; LIN-LI OU; LI ZHOU; CUI WANG. Simulating and Modeling of Intake Pipe Fuel Film Dynamic Characteristic under Gasoline Engine Transient Condition. 2008 International Conference on Intelligent Computation Technology and Automation, 2008.

YI-HU WU; ZHI-XIANG HOU; HUANCHUN GONG. Modeling and Simulation of Intake Pipe Fuel Film Dynamic Characteristic in Gasoline Engine Start Process. 2010 International Conference on Intelligent Computation Technology and Automation, 2010.

Yildiz, Y.; Annaswamy, A. M.; Yanakiev, D.; Kolmanovsky, I. Spark Ignition Engine Fuelto-Air Ratio Control: An Adaptive Control Approach. Department of Mechanical Engineering, Massachusetts Institute of Technology, Cambridge, USA e Research and Innovation Center, Ford Motor Company, Dearborn, USA, Junho 2009. 